C

$\mathrm{Pt}$

$P$

$R_{b}$

A

82

T1<smiles>[C]1C=C1</smiles>

Ni

A

$Q_{a}$

Af

To

o

q

$\sqrt{2}$

$1 \quad k$

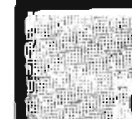

COMPARATIVE GEOGHEMICAL PROFILES OF ALASKAN.

UNHTED STATES, ANDD WOALO COALS AND COAL ASHES

s

Ir

s
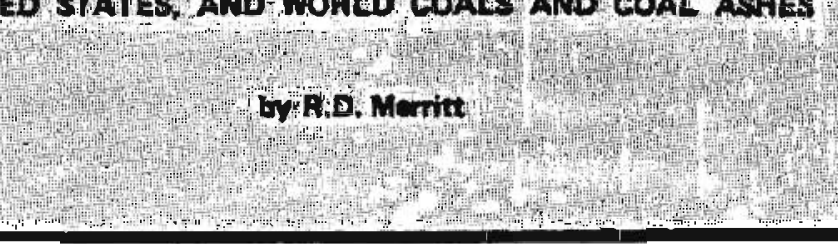

s)

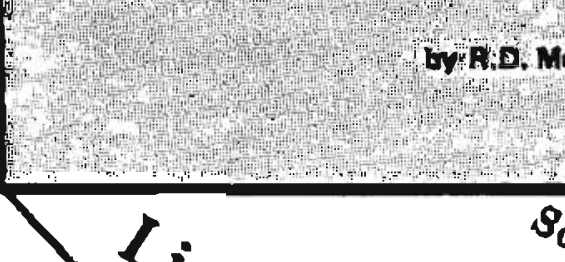

$l_{2}$

$A D$<smiles>[C]1CCCCC1</smiles>

$\mathrm{C}^{\mathrm{O}}$

Er

$\mathrm{Hg}$

Re

$A_{6}$

Ti

So

4<smiles>CCC[TeH]</smiles>

i A

5

$p$

$C_{d}$

II

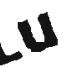

5

$r_{n}$

Yb

$M g$

$\lambda$

3

Ho

H

DY

w

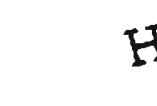

$p^{2}$

As
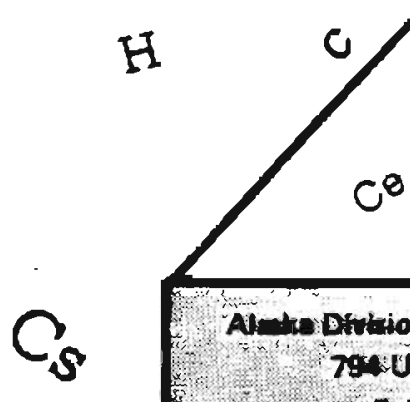

In

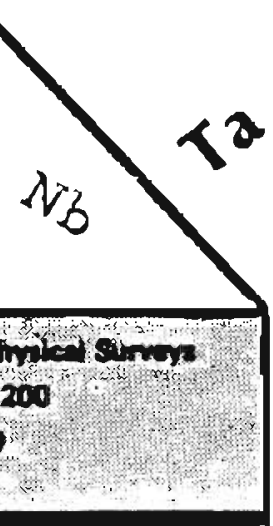

15

9

$0^{\circ}$

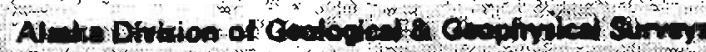

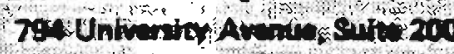

Fafbuitre Alake: 90709

Decamber 1987

$2 x$

$T_{\theta}$

Gd

$B$

$c_{4}$

Mo

$\overrightarrow{7}$

$\infty$

$o^{x}$ 
COMPARATIVE GEOCHEMICAL PROFILES OF

ALASKAN, UNITED STATES, AND WORLD COALS AND COAL ASHES

by R.D. Merritt

Alaska Division of Geological and Geophysical Surveys

THIS REPORT HAS NOT BEEN REVIEWED FOR 
Introduction .......................................

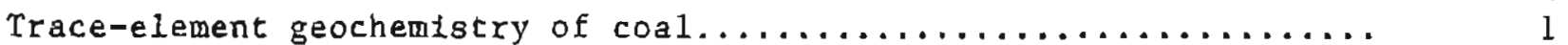

Profile 1 - aluminum $(A 1) \ldots \ldots \ldots \ldots \ldots$

Profile 2 - antimony $(\mathrm{Sb}) \ldots \ldots \ldots \ldots \ldots$

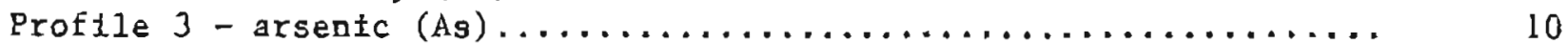

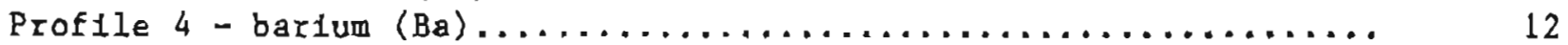

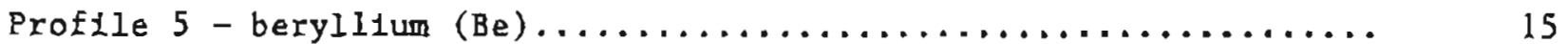

Profile 6 - bismuth $(B 1) \ldots \ldots \ldots \ldots \ldots \ldots$

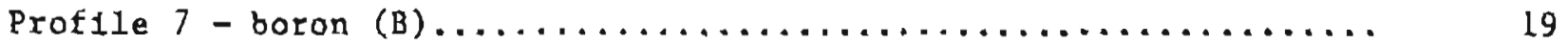

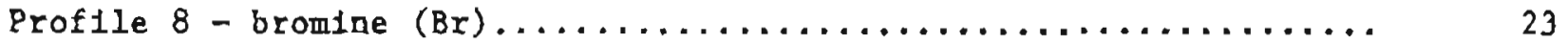

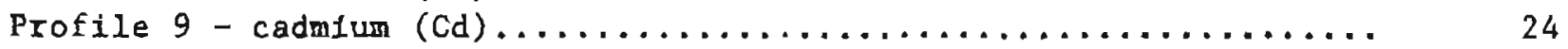

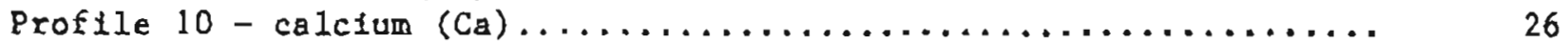

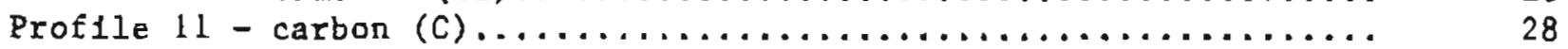

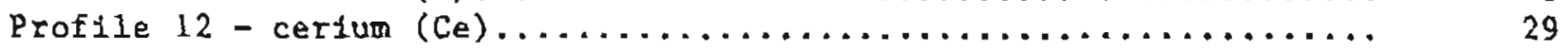

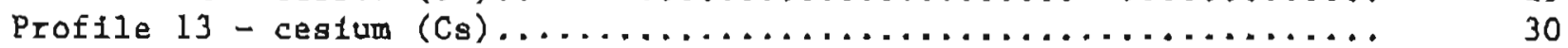

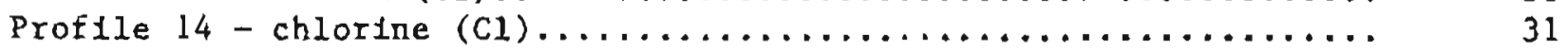

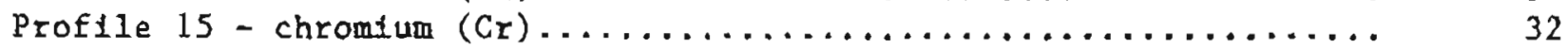

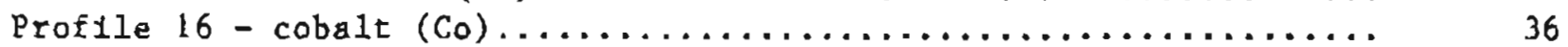

Profile 17 - copper $\left(C_{u}\right) \ldots \ldots \ldots \ldots \ldots \ldots$

Profile 18 - dysprosium (Dy) ............................. 44

Proftle 19 - erb1um $($ Er) ............................... $\ldots 5$

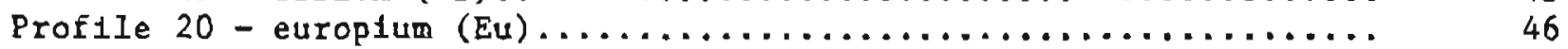

Proftle 21 - Eluorine $(F) \ldots \ldots \ldots \ldots \ldots \ldots$

Profile 22 - gadolinium $(G d) \ldots \ldots \ldots \ldots \ldots \ldots$

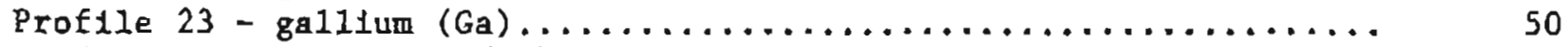

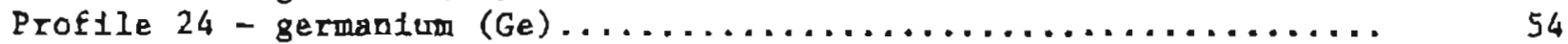

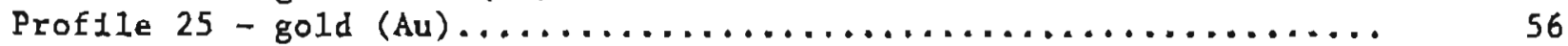

Profile 26 - hafntum (HE) .............................. 57

Proflle 27 - holmium $(\mathrm{Ho}) \ldots \ldots \ldots \ldots \ldots \ldots$

Profile 28 - hydrogen $(H) \ldots \ldots \ldots \ldots \ldots \ldots \ldots$

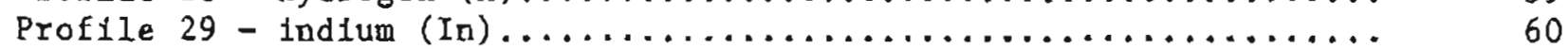

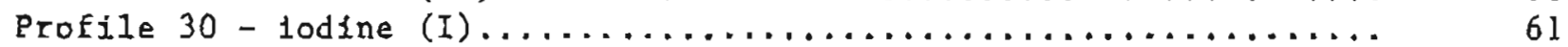

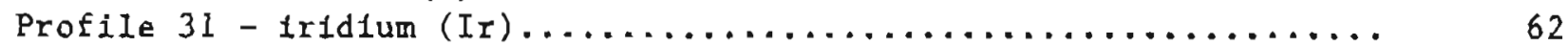

Profile 32 - iron $(\mathrm{Fe}) \ldots \ldots \ldots \ldots \ldots$

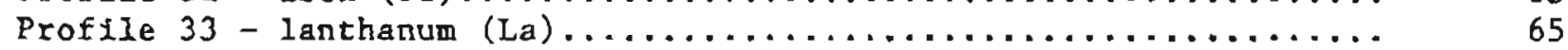

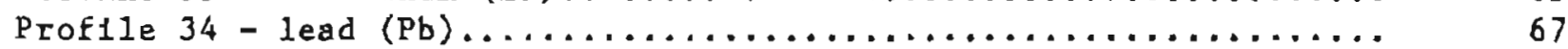

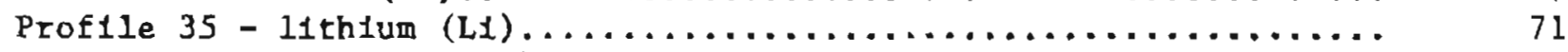

Profile 36 - lutetium $(\mathrm{Lu}) \ldots \ldots \ldots \ldots \ldots \ldots$

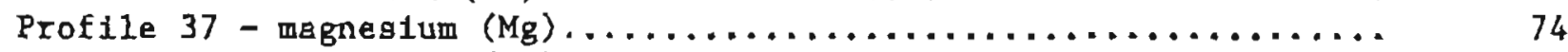

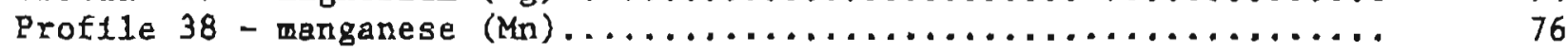

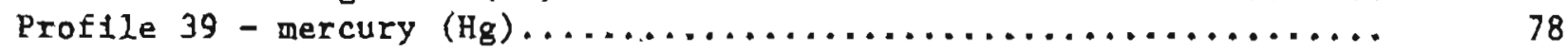

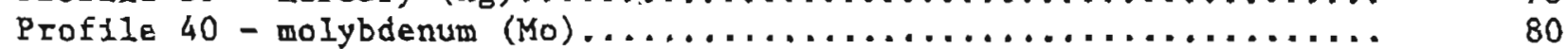

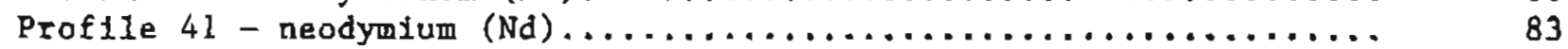

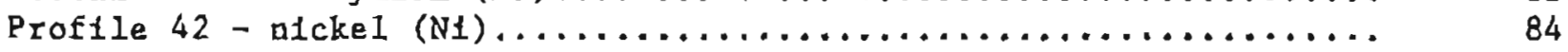

Profile 43 - niobium $(\mathrm{Nb}) \ldots \ldots \ldots \ldots \ldots$

Profile 44 - nitrogen $(\mathrm{N}) \ldots \ldots \ldots \ldots \ldots \ldots \ldots$

Proflle 45 - osmium $(0 s) \ldots \ldots \ldots \ldots \ldots \ldots$

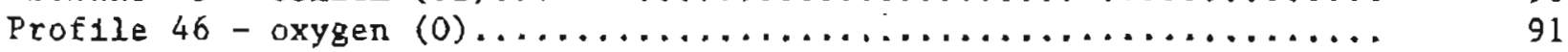

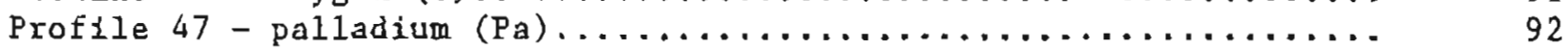

Profile 48 - phosphorus $(P) \ldots \ldots \ldots \ldots \ldots \ldots$ 


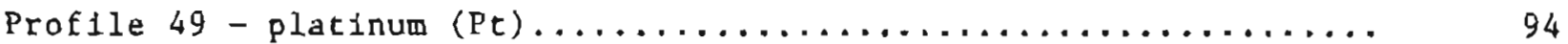

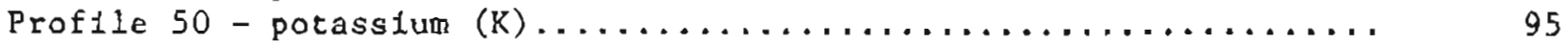

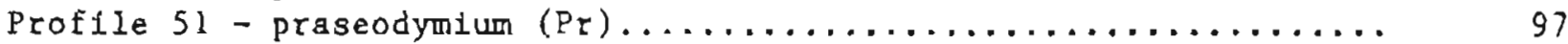

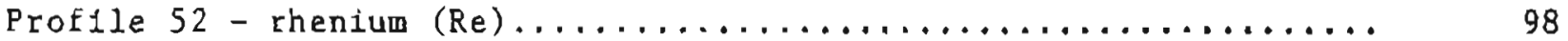

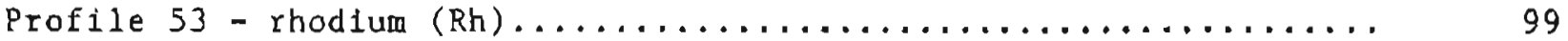

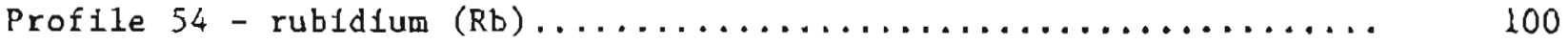

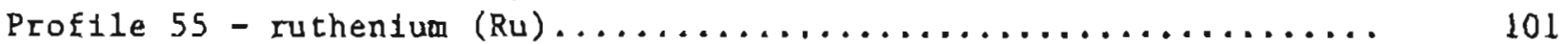

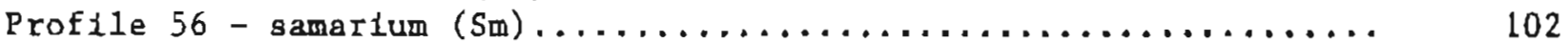

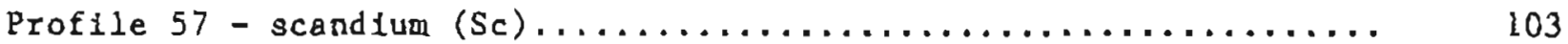

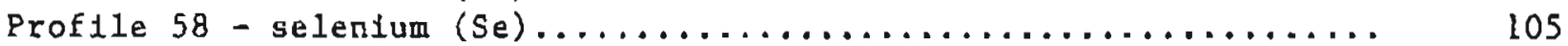

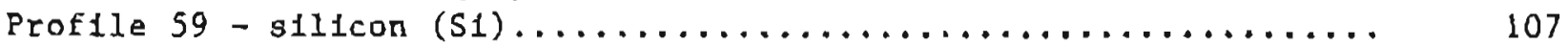

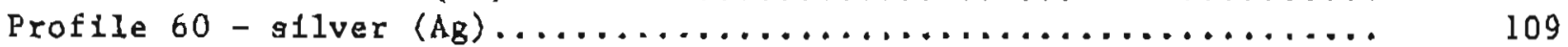

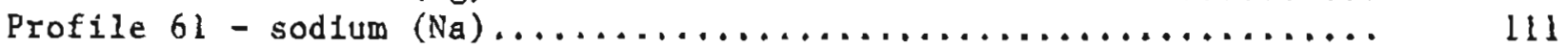

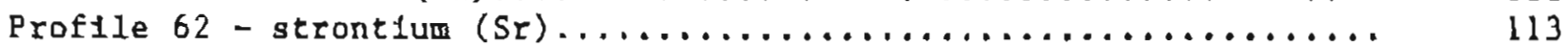

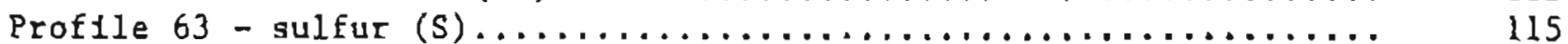

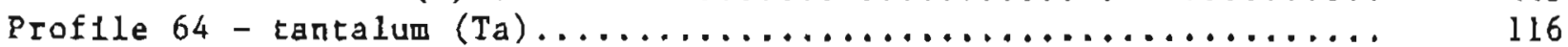

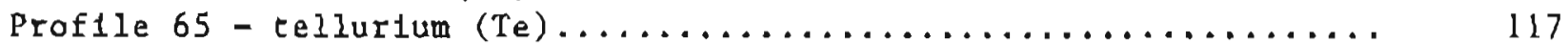

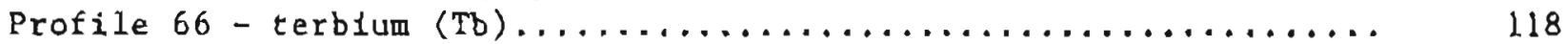

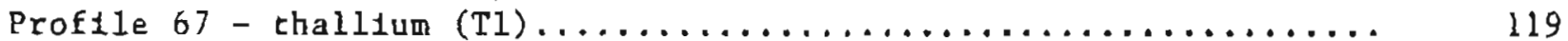

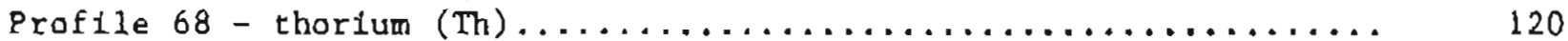

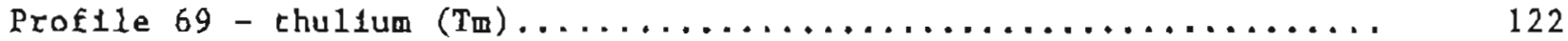

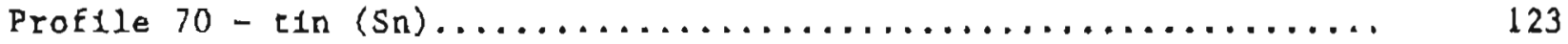

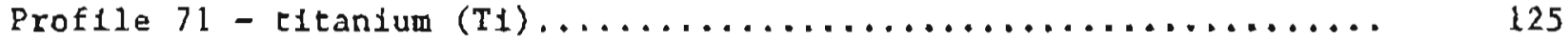

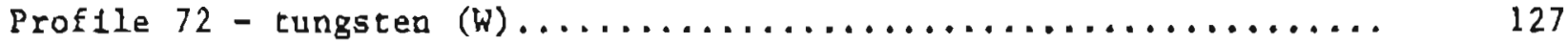

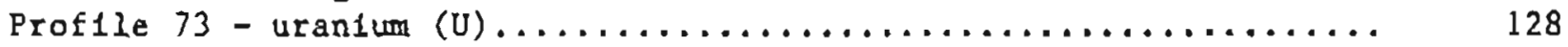

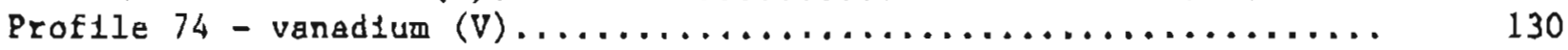

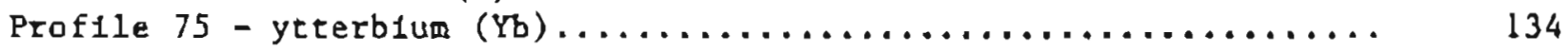

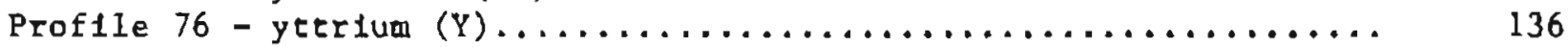

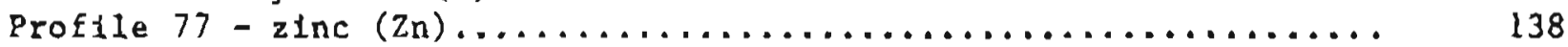

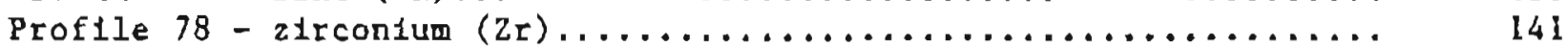

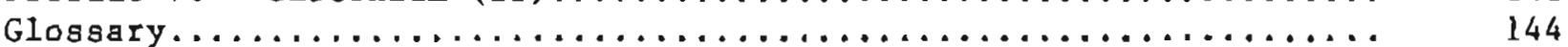

References......................................... 145

\section{FIGURE}

Figure L. Perlodic table showing those elements making up the chemlcal constitution of coal and for which detalled profiles are presented in this report............. 
COMPARATIVE GEOCHEMICAL PROFILES OF ALASKAN, UNITED STATES, AND

WORLD COALS AND COAL ASHES

\author{
by \\ R.D. Merritt
}

INTRODUCTION

The purpose of this report is to compare the geochemical nature of Alaskan, U.S., and world coals. As presently known, the chemical constitution of coal includes at a minlmum 78 elements in varylng ranges of concentration (fig. 1). Only brief consideration is given here to the major elements composing the structure of coal. More detalled data is presented relating to the trace- or minor-element components of coal. And in fact, this report emphasizes the trace-element geochemistry of Alaskan coals compared to U.S. and world coals.

There exists very little data conceraing the concentrations of certain trace elements in Alaskan, U.S., and world coals. In these cases, the insufficient data base doeg not permit an estimate to be made as to the representative range in concentration; in these instances, no estimate (N.E.) Is made.

Because Alaskan coals have been less explored, sampled and analyzed than other U.S. and world coals, the geochemical data base is relatively poorer. Baged on current knowledge, it is belleved that the concentrations of trace elements in Alaskan coals generally fall in the ranges found for other coals. Rao (1968) concluded that for the trace elements of environmental concern, none were present in abnormally greater amounts in Alaskan coals than in other U.S. or world. coals. It also appears that: 1) the concentration of mlnor elements is typlcally lower in the ash of low-rank than high-rank Alaskan coals; and 2) minor-element concentrations in coal ashes do not vary appreciably from one Alaskan coal field to another (Rao, 1968).

A brlef discussion of trace-element geochemistry of coal follows. Thereafter, comparative proflles are presented for 78 elements that make up the chemlcal constitution of Alaskan, U.S., and world coals. This report summarizes the geochemical data base as it currently exists. Although an abundant amoune of research has been conducted concerning the geochemlcal nature of coal, the elemental proflles presented in this report show that a great deal is yet to be learned. Additionally, it can be easily noted from the report where gaps in the current data base exist and where further detalled research will be required in the future.

\title{
TRACE-ELEMENT GEOCHEMISTRY OF COAL
}

Trace or minor elements are present in coal in very small concentrations and may be toxic or potentially toxic substances (U.S. Department of Energy, 1978). These elements are typically measured in parts per m1111on or even parts per billion (Averitt, 1975). Coals contaln a wide vartety of trace or minor elements including small quantitles of essentially al1 metallic and nonmetalj.1c elements (Averitt, 1961).

$\overline{\mathrm{l}}$ DGGS, 794 University Avenue, Suite 200, Falrbanks, Alaska 99709. 


\begin{tabular}{|c|c|c|c|c|c|c|c|}
\hline 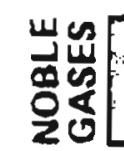 & $\infty \pm$ & $\because 2$ & $28 \overline{8}$ & $x=3$ & $x \times \frac{1}{2}$ & $6 x$ & \\
\hline$\lesssim$ & & \begin{tabular}{|r|r|} 
\\
0 \\
0
\end{tabular} & $\approx \sigma \frac{0}{0}$ & 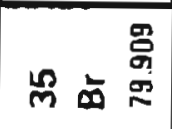 & 8 - & $8 \div$ & \\
\hline$\$$ & & 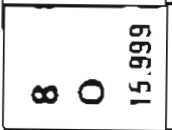 & Os & 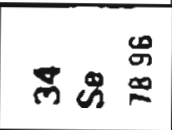 & 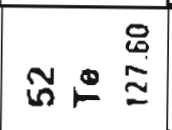 & D̊을 & \\
\hline$\$$ & & A $2 \stackrel{\grave{q}}{=}$ & 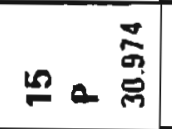 & 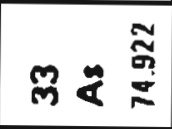 & 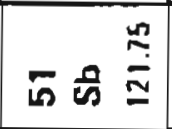 & 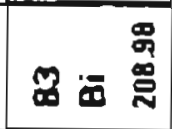 & \\
\hline$\geqq$ & & 000 & \pm is & พิ & 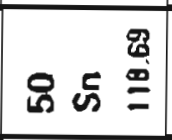 & $\widetilde{\infty} \frac{9}{\bar{\Sigma}}$ & \\
\hline$\leqq$ & & $n \infty \overline{\overline{\overline{\hat{\theta}}}}$ & 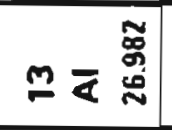 & $\bar{m} \mathrm{~g}$ & $q \leq \stackrel{\varpi}{\Xi}$ & $\bar{\infty}=\overline{9}$ & \\
\hline$\stackrel{\infty}{=}$ & & & & 官空 & 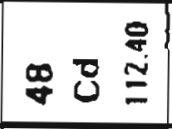 & 离影 & \\
\hline$\underline{\underline{ }}$ & & & & 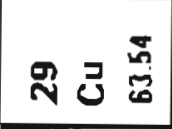 & 용 & 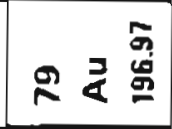 & \\
\hline$\stackrel{\square}{\bar{\Sigma}}$ & & & & 罢立空 & 果 こ & 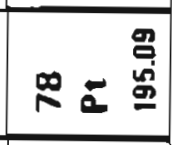 & \\
\hline$\equiv$ & & & & సᄋ & 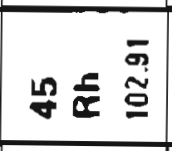 & $\Sigma=\tilde{\Xi}$ & \\
\hline 5 & & & & 电湾 & F $z \stackrel{0}{x}$ & Rั & \\
\hline$\stackrel{\infty}{\overline{5}}$ & & & & $2 \frac{6}{2}$ & 马ே & 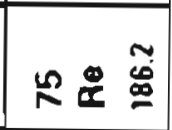 & \\
\hline$\stackrel{n}{\nu}$ & & & & 司兽 & 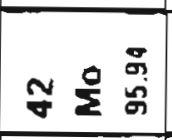 & $\pi 3 \stackrel{\stackrel{m}{m}}{\underline{m}}$ & \\
\hline 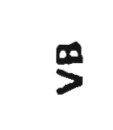 & & & & $\tilde{N}>\mathbf{D}$ & 印兽 & 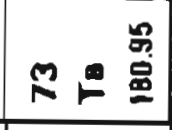 & 8 \\
\hline$\stackrel{m}{\geq}$ & & & & N $:=\stackrel{8}{8}$ & 守心華 & $\approx \Sigma$ & 8 \\
\hline$\stackrel{\varrho}{\Xi}$ & & & & $\bar{\sim}$ & 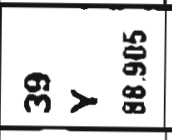 & 6. & 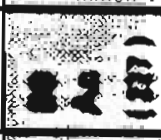 \\
\hline$\varangle$ & & ○ & 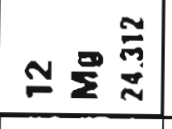 & 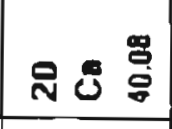 & 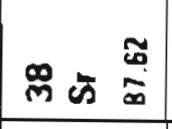 & 品要产 & $x^{2}$ \\
\hline$\leq$ & 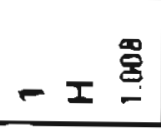 & $m=\begin{array}{c}0 \\
\vdots \\
\omega\end{array}$ & 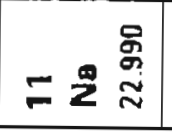 & $a_{x} \stackrel{\Xi}{m}$ & $\bar{m} \vec{x} \overline{0}$ & 员怘 & 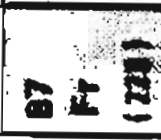 \\
\hline
\end{tabular}

\begin{tabular}{|c|c|}
\hline 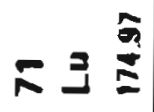 & $\forall=\hat{8}$ \\
\hline 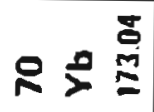 & 2 \\
\hline 吕 E 宫 & \\
\hline 品岀 & \\
\hline 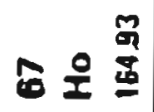 & \\
\hline 舟苋 & \\
\hline 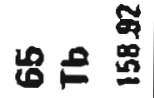 & \\
\hline$\delta \vec{~}$ & \\
\hline ஜூ & \\
\hline 중 & 롤 \\
\hline & \\
\hline $8 \geq \frac{\check{y}}{2}$ & 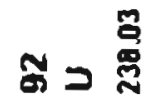 \\
\hline 品亡 & \\
\hline 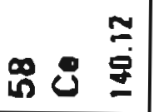 & 吕卡 $\stackrel{\text { 号 }}{\sim}$ \\
\hline
\end{tabular}


Major oxides compose 93 to 98 percent of the total weight of coal ash (Selvig and Gibson, 1956). The remainling few percent 1s made up mostly of about 25 different minor elements. The usual concentrations of minor inorganic or trace constituents in the earth's crust are quite low, but very rare mineable deposits of certain trace elements exist (U.S. Department of Energy, 1978). Indeed, one of the main reasons for studying trace elements in coal is the possibility of recovering certain elements in commerclal quantities. In addition, trace elements have been used as indicator elements for geological 1nvestigations (Stach and others, 1982) and have been applied to correlating coal seams (McClung and Geer, 1979).

Gluskoter and others (1977) established the following generallzarions relating to elemental concentrations based on chemical analyses of whole coal samples: 1) Elemental concentrations were hlghest in coals of the Appalachian region, intermediate in Illinois basin coals, and lowest in Wegtern U.S. coals; 2) the elements exh1biting the largest ranges in concentration occurred in distinct mineral phases (as sulfide and sulfate minerals, for example) in the coals. Conversely, elements exhibiting narrow ranges in concentration or smaller standard deviations were associated with sllicate minerals or found in organic combination in coal; 3) most of the elemental concentrations in coals are lower than the clarke values of the elements; 4) different benches of a coal sean can show wide variations in elemental concentracions; 5) concentrations of elements are more commonly found at the top and/or boctom of coal seams; 6) f1ne-grained sedimentary rocks 1nt1mately assoclated with the coals--roof shales, underclays, and partings--contain significantly higher concentrations of most elements than the coals themselves; and (7) the relative organlc affinity of elements can be establlshed by analyzing washed samples at spectflc gravity fractions.

Trace elements are introduced into coal in one of four different ways: 1) As an inert material washed into the coal swamp at the time of plant accumulation; 2) as a chemical preclpitate from swamp water; 3) as a minor constituent of orlginal plant cells; or 4) as a later addition, introduced after coal formation primarlly by downward and laterally moving ground water (Aver1tt, 1961). Weathering processes may signiflcantly increase the miror element content in coal (Zubovic and others, 1966a,b).

Rapid substdence durlng sedimentation results in lower trace element contents in coals (Horne and other, 1978). Slow subsidence favors higher contents of chemically precipitated material. Coals of the lower delta plain eavironment show a highly irregular pattern of trace-element distribution (Horne and others, 1978).

Mineral matcer of coal can be defined broadly to include all inorganic elements. Several trace and minor elements have been ldentifled as occurring 1n discrete mineral phases in coal (Ruch and others, 1974). Trace elements in coal can be concentrated in various trace minerals rather than incorporated in major or minor mineral components (Meyers, 1982).

Coal-quallty evaluations should include detailed and regional analyses of the inorganic consticuents (Altschuler and Johnston, 1976). Trace-element characterizacion should involve a systematic study of trace-element 
assemblages (Meyers, 1982). A slgniflcant problem in the analysis of trace elements is that there has not been any coal standards avallable until recent years (Gluskoter, 1975).

Gluskoter and others (1977) showed that most of the trace elements in coal had inorganic affinities. Trace elements in the inorganic group are separable from the coal substance because of the higher specific gravity of the host minerals (Cavaliaro and others, 1978). Certain trace elements are assoclated with the organic phase of coal (Rao, 1976). Elements with high organic affinity are more or less concentrated in the washed or clean coal (Stach and others, 1982).

From mine to utilization, varlous trace contaminants in coal are released 1nto the environment. The soluble forms of trace elements can be released into the environment by aqueous leaching of coals or their residues (Wewerka and others, 1976). Environmental conslderations are among the main reasons for trace-element analysis of coals. Trace-element analysis has assumed added 1mportance relarive to coal utilizacion and environmental impact, and trace elements have become an increasingly important factor in environmental laws.

Trace metals can be transported long distances through alr and water and passed along the food cha1n with little change in chemlcal properties (U.S. Department of Energy, 1978). Many of the trace elements are not toxic in thelr elemental form, but their ions and compounds can be quite harmful (U.S. Department of Energy, 1978). Potentlally toxlc trace elemeats Include mercury, arsenic, lead, cadmium, selenium, and fluorine (Berkowitz, 1979).

The trace components of coal are complexed with orgentc matter and are only isolated by combustion (Berkowitz, 1979). When coal is burned, most of the minor elements are concentrated in the ash (Averitt, 1975). During combustion at high temperatures, the more volatile trace elements can vaporize to exit the boller in a gaseous state, or they may form particulates which aze then entrained in the exhaust (Averitt, 1975; U.S. Department of Energy, 1978). Certain elements may become condensed or adsorbed on the surface of fly-ash enlssions or other encrained particulate watter (Mraw and others, 1983). The pollutants include some toxic trace elements along with more inert gaseous products.

Little documentation extsts concerning the pollution effects of bigh levels of trace elements from the burning of coals. As more coal is consumed in the future, trace elements will be emitted in greater quantitieg. As coal consumption and fosill-fuel combustion increases, these trace pollutants and their effects will cause Increasing concern (U.S. Department of Energy, 1978). Because of this growing concern over air quality, analytical studies of trace elements in coal have been accelerated.

In some cases, the trace constituents of fly ash have been show to represent a serfous public-health hazard (Berkowitz, 1979). The presence of trace elemencs in fly ash from combustion processes, especially in the respirable size fractions, is considered to be potentially hazardous (Mraw and others, 1983). 
Some minor and trace elements may be critical factors in process technology (Altschuler and Johnston, 1976). Trace elements in coal can cause technological difficulties including various effects on combustion processes ani equipment (Stach and orhers, 1982).

Coal-quality factors, Including trace-element geochemistry, will assume greater importance in the future marketplace (Orhe1m, 1979). Because of the greater welght placed on coal-quality criteria, the market will resultantly become more selective. 


\section{PROFILE 1 - ALUMINUM}

Symbol: Al

Atomic number: 13

Atomic welght: 26.9815

\begin{tabular}{|c|c|c|c|}
\hline & $\operatorname{Cos} 1$ & & Ash \\
\hline Alaska & $1,000-70,000$ & ppm & N.E. \\
\hline U.S & $3,000-35,000$ & ррг & $50,000-220,000 \mathrm{ppm}$ \\
\hline World & $4,000-31,000$ & ppm & N.E. \\
\hline
\end{tabular}

Aluminum is an lmportant metallic element that is only found in combination. It is the most abundant element in the earth's crust. Aluminum is a major inorganic element in the mineral constituents of coal. It is mainly associated with the aluminosilicate group of minerals. Aluminum oxtde is one of the major constituents of coal ash. Alumloum has an 1mportant effect on the use of coal in combustion and cokemaking.

Tureklan and Wedepohl (1961) reported the following average aluminum concentrations in common sedimentary rocks: shales, 80,000 ppm; sandstones, $25,000 \mathrm{ppm}$; and carbonaces, 4,200 ppm.

\section{World Coals}

Wewerka and others (1976) reported a range 1n aluminum content of 0.4 to 3.1 percent in coal. The L.S. National Committee for Geochemistry (1980) ciced a worldwide average aluminum content in coal of 1.0 percent. Abernethy and Cibson (1963) reported an average aluminum concentration of $10,440 \mathrm{ppm}$ in coal.

\section{Untted States Coals}

Aluminum has been found to range from 0.43 to 3.04 percent in U.S. coals and to exhibit an average concentration of 1.4 percent (Los Alamos Sclentific Laboratory, 1976; U.S. National Comnttee for Geochemistry, 1980). Sharkey and others (1975) found that aluminum occurred in 100 percent of $13 \mathrm{U} . \mathrm{S}$. raw coals analyzed, and that 1 ranged in concentration from 3,000 to 23,000 ppm. Swanson and others (1976) reported an average concentration of 1.1 percent aluminum in 601 U.S. whole-coal samples. Concentrations of aluminum in U.S. coals by rank are: anthracite, 2.0 percent, bituminous, 1.4 percent; subbituminous, 1.0 percent; and 11 gatte, 1.6 percent. Aluminum content in ashes of U.S. coals has been found to range from 5.3 to 21.2 percent (Los Alamos Sclentific Laboratory, 1976).

Appalachlan region. Swanson and others (1976) reported a geometric mean content of 1.3 percent aluminum in 331 Appalachian region whole-coal samples. Gluskoter and otherg (1977) found a geometric mean of 1.6 percent aluminum in 23 Appalachian region coals.

Interior region. Swanson and others (1976) clted a geometric mean aluminum content of 0.77 percent in 194 Interior region whole-coal samples. cluskoter and others (1977) reported a geometric mear of 1.2 percent aluminum in 113 Illinols basin whole-coal samples. 
Western region. Swanson and others (1976) reported a geometric mean of 0.59 percent aluminum in 93 Western region whole-coal samples and a geometric mean of 1.6 percent aluminum for 34 Texas coals. Gluskoter and others (1977) found a geometric mean aluminum content of 0.88 percent in 29 Western U.S. whole-coal samples.

\section{Alaska Coals}

Based on samples of six coal beds from the Tyonek Formation, Beluga fitld, Affolter and Stricker (1984) found that the concentration of aluminum varled directly with the ash content of the coals.

Affolter and others (1981) reported geometric mean aluminum concentratlons of 0.97 percent, 1.1 percent, 1.2 percent, and 0.76 percent in whole-coal samples of the Healy (20), Kenal (10), Seldovia (34) and Utukok River (54) Quadrangles, respectively. Compared to aluminum contents in 410 Powder River region coal samples, the aluminum concents of coals of the Healy, Kena1, and Seldovia Quadrangles are signiflcantly higher. Compared to aluminum contents in 295 Rocky Mountain province coal samples, the aluminum contents of Utukok River Quadrangle coals are significantly lower. 
PROFILE 2 - ANTIMONY

Symbol: $\mathrm{Sb}$

Atomlc number: 51

Atomic weight: 121.75

$\begin{array}{ll} & \frac{\text { Coal }}{5-10} \mathrm{ppm} \\ \text { Alaska } & 0.05-20 \mathrm{ppm} \\ \text { U.S. } & 0.1-205-10 \mathrm{ppm} \\ \text { World } & 0.05\end{array}$

Antimony is a metallic element that is used in a wide varlety of alloys. It is one of the elements assoclated with both organic and Inorganic mater, but is more closely allied with organic Eractions (Ruch and others, 1974). Up to 50 percent of antimony is lost in low-temperature ash. It can be enrlched on the surfaces of fly-ash particles from coal-fired plants (Mraw and ochers, 1983). Anomalously high antimony can result in samples from core holes contaminated by drilling fluids and drill plpe.

Antimony shows a moderate enrichment factor of $5.5 \mathrm{X}$ in coal ash compared to its average estimated concentration in the earth's crust (U.S. National Committee for Geochemistry, 1980). Turektan and Wedepoh1 (1961) reported the following average antimony concentrations in common sedimentary rocks: shales, 1.5 ppm; sandstones, $0.0 \mathrm{X} \mathrm{ppm} ;$ and carbonates, $0.2 \mathrm{ppm}$. Orheim (1979) reported the following clarke values for antimony: earth's crust, $0.2 \mathrm{ppm} ;$ soil, $0.5 \mathrm{ppm}$; plant ash, $1.0 \mathrm{ppm}$; and water 0.001 ppm.

\section{World Coals}

Abernethy and Gibson (1963) Eound an average antimony content of 0.5 ppm In cosl. The U.S. National Committee for Geochemistry (1980) reported an average worlduide concentration of $3.0 \mathrm{ppm}$ antimony in coal.

\section{United States Coals}

Sharkey and others (1975) found that antimony occurred in 92 percent of 13 U.S. raw coals analyzed, and that 1 t ranged in concentration of $<0.1$ to 2 ppm. Los Alamos Scientific Laboratory (1976) cited an antimony range in concentration of 0.2 to 9 pprn in U.S. coals. Swanson and others (1976) found an average content of 0.7 PPR antimony in $601 \mathrm{U} . \mathrm{S}$, whole-coal samples. The U.S. National Committee for Geochemistry (1980) reported an average antimony concentration in U.S. coals of $1.1 \mathrm{ppm}$.

The U.S. National Comittee for Geochemistry (1980) gave mean concentratlons of antimony in U.S. coals of various rank as follows: anthracite, $0.9 \mathrm{ppm} ;$ bituminous, $1.4 \mathrm{ppm}$; subbituminous $0.7 \mathrm{ppm}$; and $11 \mathrm{gnite} 0.7 \mathrm{ppm}$. A range in ancimony content of $<40$ to $230 \mathrm{ppm}$ has been reported for U.S. coal ashes (Los Alamos Sclentific Laboratory, i976).

Appalachian region. Swanson and others (1976) reported a geometric mean content of 0.8 ppr antimony in 331 Appalachian region whole-coal samples. Gluskoter and others (1977) reported a geometric mean content of 1.1 ppm antimony in 23 Appalachian region coals. 
Interior region. Swanson and others (1976) reported a geometric mean content of $0.8 \mathrm{ppm}$ antimony in 194 Interior region whole-coal samples. Gluskoter and others (1977) cited a geometric mean content of $0.81 \mathrm{ppm}$ antimony in 113 Illinois basin whole-coal samples.

Western region. Swanson and others (1976) reported a geometric mean content of 0.4 ppm antimony in 93 Western region whole-coal samples and a geometric mean content of 0.7 ppm antimony in 34 Texas coals. Gluskoter and others (1977) found a geometric mean content of 0.45 ppm antimony in 29 Western U.S. coals,

\section{Alaska Coals}

Compared to other U.S. coals, the content of antimony is low in Alaskan coals.

Northern Alaska province. Conwell and Triplehorn (1976) found an average concentration of $1.3 \mathrm{ppm}$ antimony in a Kukpuk River whole-coal sample and 2.l ppm antimony in a Cape Thompson coal. Affolter and others (198I) reported a range of 0.05 to $0.64 \mathrm{ppm}$ antimony in 54 Utukok River Quadrangle whole-coal samples and a geometric mean content of 0.1 ppu antimony.

Cook Inlet-Susitna province. Merritt (1985b) found a mean concentration of 1.1 ppm antimony in 19 Matanuska Valley coal-ash samples. Affolter and others (1981) reported a range in antimony of 0.2 to $1.3 \mathrm{ppm}$ for 10 Kenai Quadrangle whole-coal samples and a geometric mean of $0.6 \mathrm{ppm}$. They also reported a range in antimony of 0.2 to $3.7 \mathrm{ppm}$ for 34 Seldovia Quadrangle coals and a geometric mean of $1.0 \mathrm{ppm}$. Conwell (1977) reported a range in antimony concentration of 0.4 to $1.9 \mathrm{ppm}$ for seven Beluga fleld whole-coal samples and a mean of $1.0 \mathrm{ppm}$.

Nenana province. Affolter and others (1981) cited a range in antimony concentration of $0.3-8.1 \mathrm{ppm}$ in 20 healy Quadrangle whole-coal samples and a geometric mean cootent of $1.3 \mathrm{ppm}$. Affolter and stricker (1987) found an average antimony concent of $0.2 \mathrm{ppm}$ for two whole-coal samples of Seam No. 3 , lsibel11 Mine.

Alaska Penlnsula province. Conwell and Triplehorn (1978) reported an average concentration of antimony of $0.6 \mathrm{ppm}$ in elght Alaska Peninsula whole-coal samples. 
PROFILE 3 - ARSENIC

Symbo1: As

Atomic number: 33

Atomic welght: 74.9216

$\begin{array}{ll} & \frac{\text { Coa } 1}{5-25} \mathrm{ppm} \\ \text { Alaska } & 0.5-110 \mathrm{ppm} \\ \text { U.S. } & 0.5-100 \mathrm{pom} \\ \text { World } & 0.5-100\end{array}$

$$
\begin{gathered}
\frac{\text { Ash }}{\overline{N . E}} \\
20-600 \text { ppun } \\
10-8,000 \text { ppw }
\end{gathered}
$$

Arsenic is a highly poisonous metallic element. It is a common minor element in coal, and is mainly assoclated with the sulfide group of minerals, especially arsenopyrite (FeAsS). High-pyrite coals usually contain higher concentrations of arsenic than other coals. Lesser amounts of arsenic are contalned in the clay minerals and organic matter of coal (Aver1tt, 1975). Arsentc is generally 1norganically combined in coal, and is one of the elements showing least organic affintty. It is typically concentrated in the mineral matter of coal (Ruch and others, 1974).

Arsenic is one of the elements of chlef environmental concern in coal; it is generally toxic to plant and animal life at relatively low concentrations (Ruch and others, 1974). Although over 95 percent of arsenic is retalned in low-cemperature ash (Ruch and others, 1974), it can be volatilized during coal combustion and released from coal-fired plants. It can be enrlched on the surfaces of fly-ash particles emanating from coalf1red plants (Mraw and others, 1983). Arsenic may precipitate in the superheater tubes of bollers, in stacks and dust chambers. With pyrite removal from coal, arsentc emissions are significanty lowered (Averttt, 1975).

Arsentc is pregent in coal in concentrations sigalficantly greater than its clarke value (Gluskoter and ochers, 1977). It shows a moderate enrlchmenc factor of $8.3 \mathrm{X}$ in coal ash compared to its average estimated concentration in the earth's crust (U.S. National Committee for Geochemistry, 1980). Turekian and hedepoh1 (1961) reporced the following arsenic concentrations in common sedimentary rocks; shales, 13 ppm; sandstones, 1 ppm; and carbonates, 1 ppm. Orhelm (1979) reported the following clarke values for arsenic: earth's crust, $2 \mathrm{ppw}$; sol1, $5 \mathrm{ppm}$; plant ash, $4 \mathrm{ppm}$; and water, $0.003 \mathrm{ppm}$.

\section{World Coals}

Abernethy and Gibson (1963) reported an average arsenic content of coal of $4.45 \mathrm{ppm}$. The U.S. National Commitree for Geochemistry (1980) c1ted a worldwide average arsentc concentration tn coal of 5 ppm. Berkowltz (1979) cited a maximum concentration of arsenic in coal ash of $8,000 \mathrm{gm} / \mathrm{ton}$ and an average concentration of $500 \mathrm{gm} / \mathrm{ton}$.

\section{United States Coals}

Sharkey and others (1975) found that arsen1c occurred 1n 100 percent of 13 U.S. raw coals analyzed, and that it ranged in concentration from 1 to $10 \mathrm{ppm}$. Los Alamos Sclentific Laboratory (1976) reported an arsenic range of 0.5 to $106 \mathrm{ppw}$ in U.S. whole coals, and 21 to $570 \mathrm{ppm}$ in coal ashes. Swanson and others (1976) Found a geometric mean arsentc content of 7.5 ppm in 601 
U.S. whole-coal samples. The U.S. National Commttee for Geochemistry (1980) cited a U.S. average arsentc concentration of $15 \mathrm{ppm}$ in coal.

Appalachian region. Swanson and others (1976) reported a geometric mean content of $11 \mathrm{ppm}$ arsenic in 331 Appalachian region whole-coal samples. Gluskoter and others (1977) reported a geometric mean content of 15 ppm arsentc in 23 Appalachian region coals.

Interior region. Swanson and others (1976) reported a geometric mean content of $12 \mathrm{Ppm}$ arsenic in 194 Interior region whole-coal samples. Gluskoter and ochers (1977) reported a geometric mean content of $7.4 \mathrm{ppm}$ arsentc in 113 Illinols basin coals.

Western region. Swanson and otherg (1976) reported a geometric mean content of 2 ppl arsenic $1 \mathrm{n} 93$ Western region coals and a geomecric mean content of 5 ppo arsenic $1 n 34$ Texas cosls. Gluskoter and others (1977) reported a geometric mean content of $1.5 \mathrm{ppm}$ arsenic in 29 Western U.S. coals.

\section{Alaska Coals}

Compared to other U.S. coals, the content of arsenic in Alaskan coals is generally lower or gimflar.

Northern Alaska province. Conwel1 and Triplehora (1976) found an average concentration of 3.5 ppm arsenic in a Kukpuk Rlver whole-coal sample and 21 ppm arsealc in a Cape Thompson coal. Affolter and others (1981) reported a range of 0.7 to $8.1 \mathrm{ppm}$ arsentc $1 \mathrm{n} 54$ Utukok River Quadrangle whole-coal samples and a geometric mean content of $2.0 \mathrm{ppm}$.

Cook Inlet-Susitna province. Merritt (1985b) found a mean concentration of 5.4 ppm arsenic in 31 Matanuska Valley coal-ash samples. Affolter and others (1981) reported a range in arsentc of 2 to $5 \mathrm{ppm}$ for 10 Kena1 Quadrangle whole-coal samples and a geometric mean of $3.4 \mathrm{ppm}$. They also reported a range in arsentc of 2 to $25 \mathrm{ppm}$ for 34 Seldovia Quadrangle coals and a geometric mean of $7.2 \mathrm{ppm}$. Conwel1 (1977) reported a range in arsenic concentration of 2.0 to $7.5 \mathrm{ppm}$ for seven Beluga field whole-cosl samples and a mean content of $4.8 \mathrm{ppm}$.

Nenana province. Affolter and others (1981) cited a range in arsentc concentration of 1 to 10 ppm in 20 Healy Quadrangle whole-coal samples and a geometric mean content of $2.6 \mathrm{ppm}$. Affolter and Stricker (1987) found an average arsenic concentration of $2.2 \mathrm{ppm}$ for two whole-coal samples of Seam No. 3, Ualbelli Mine.

Alaska Peninsula province. Conwell and Triplehorn (1978) reported an average concentration of arsentc of 6.6 ppo in elght Alaska Peninsula whole-coal samples. 


\section{PROFILE 4 - BARIUM}

Symbol: $\mathrm{Ba}$

Atomic number: 56

Atomlc weight: 137.34

$\begin{array}{lc} & \frac{\text { Coal }}{\text { Alaska }} \\ \text { U.S. } & 100-3,000 \mathrm{ppm} \\ \text { World } & <100-2,000 \mathrm{ppr} \\ & \text { N.E. }\end{array}$

Barium is an alkaline-earth metallic element that generally occurs in association with the mineral bartie ( $\mathrm{BaSO}_{4}$ ) in coals. Barium oxide (BaO) usually exhibits significant, but not large, concentrations in the ash of some coals. Barlum in coal results primarily from the remalning constivuents of original plant cells, but secondary amounts appear to result from enrichment by circulating ground water (Averitt, 1961).

Barium occurs in appreciably greater concentration in coal than its estimated average concentration in the earth's crust (Aver1tt, 1961). Turektan and Wedepoh1 (1961) reported the followlng average barium concentrations in common sedimentary rocks; shales, 580 ppm; sandscones, X0 ppm; and carbonates, $10 \mathrm{ppm}$. Orhelw (1979) reported the following clarke values for bartum: earth's crust, 425 ppm; so1l, 500 ppm; plant ash, $280 \mathrm{ppm}$; and water $0.03 \mathrm{ppm}$.

\section{World Coals}

Abernethy and Gibson (1963) found an average barium content of 65 ppw in coal. The U.S. National Comittee for Geochemistry reported an average worldwide concentration of 500 ppm barlum in coal.

\section{United States Coals}

Sharkey and others (1975) found that bartum occurred in 100 percent of 13 U.S. raw coals analyzed, and that 1 t ranged in concentration from 20 to 1,600 ppm. Los Alamos Sclentific Laboratory (1976) cited a bartum range in concentration in ash of U.S. coals of 0.01 to 1.39 percent, and l1sted average barlum concentrations in ashes of U.S. coals of various ranks as foliows: anthrac1te, $866 \mathrm{ppm}$; low-volatile bituminous, $740 \mathrm{ppw}$; mediumvolatile bttuminous, $896 \mathrm{ppm}$; high-volatile bituminous 1,253 ppm; and subbitumioous and lignite, 5,027 ppm.

Swanson and others (1976) found an average content of 137.7 ppm barfum In 601 U.S. whole-coal samples. The U.S. National Comitcee for Geochemistry (1980) reported an average barium concentration in U.S. coals of $150 \mathrm{ppm}$.

Appalachian region. Swanson and others (1976) reported a geometric mean content of 70 ppm barlum in 331 Appalachian region whole-cosi samples. Gluskoter and others (1977) reported a geometric mean content of 170 ppm bartum in 14 Appalachian region coals.

Intertor region. Swanson and others (1976) reported a geometric mean content of 30 ppm barium in 194 Interlor region whole-coal samples. 
Giuskoter and others (1977) clted a geometric mean content of 75 ppm barium In 56 Illinols bastn whole-coal samples.

Western region. Swanson and others (1976) reported a geometric mean content of 300 ppr barium in 93 Western reglon whole-coal samples and a geometric mean content of $150 \mathrm{ppm}$ barlum in 34 Texas coals. Gluskoter and others (1977) Found a geometric mean content of 430 ppm bartum in 22 Western U.S. coals.

\section{Alaska Coals}

Compared to other U.S. coals, the content of barlum in Alaskan coals tends to be higher.

Northern Alaska province. Rao (1968) reported an average concentration of $670 \mathrm{ppm}$ barfum in 12 Northern Alaska whole-coal samples; the total average barium concentration in ash samples of the same coals was 6,915 ppm. Conwell and Triplehorn (1976) found an average concentration of 2,000 ppm barium in a Kukpuk River coal-ash sample and 1,000 ppm barium in a Cape Thompson coal. Rao and Wolff (1981) reported $470 \mathrm{ppm}$ barlum in a Walnwright subbituminous $B$ whole-coal sample, and 7,900 ppw barlum in the ash of the same coal. They also reported a barium content of 210 ppr for a Meade River subbituminous $B$ whole-coal sample, and 4,800 ppm barlum in the ash of the same coal. Affolter and others (1981) reported a range of 100 to 2,000 ppm barium in 54 Utukok River Quadrangle whole-coal samples and a geometric mean content of 700 ppm bartum.

Cook Inlet-Susitna province. Rao (1968) reported an average barium concentration of 623 ppm in 22 Matanuska Valley whole-coal samples and 4,454 ppm barium in ash samples of the same coals. Merritt (1985b) found a mean concentration of 579 ppm barlum in 22 Matanuska Valley coal-ash samples. Rao and Wolff (1981) found that the lower seam (hvb rank), Castle Mountain Mine, contained $620 \mathrm{ppm}$ barium on a whole-coal basis and 3,400 ppm in coel. ash.

Rao (1968) reported an average concentration of $282 \mathrm{ppm}$ barium in elght Kenal field whole-coal samples; coal ash of the same samples contained an average barlum content of $2.925 \mathrm{ppm}$. Rao and wolff (1981) c1ted a barlum content of $520 \mathrm{ppm}$ in a sample of the subbituminous C-ranked Cabin bed, Kena1 fleld; the sample showed an ash concentration of 5,500 ppm barlum. Affolter and others (1981) reported a range 1n bar1um of 500 to $700 \mathrm{ppm}$ for 10 Kenal Quadrangle whole-coal samples and a geometric mean of $500 \mathrm{ppm}$. They also reported a range in barium of 150 to 1,000 ppra for 34 Seldovia quadrangle whole-coal samples and a geometric mean of $500 \mathrm{ppm}$. Merritt and others (1987) found that the average concentration of bartum in the ash of 31 Kenat fleld coals was $3,198 \mathrm{ppm}$.

Conwell (1977) reported a range in barlum concentration of 3,000 to 10,000 ppw for ash samples of seven Beluga fleld coals and a mean content of 6,860 ppm bartum. Rao and holff (1981) found that a whole-coal sample of the subbituminous C-ranked Waterfall Seam, Beluga fleld contained 490 ppm barium; ash of the same coal contained 5,200 ppm barium. They found that a 
whole-coal sample of the Sunflower Creek seam, a lignite, contalned 230 ppm barlum, and that ash of the same coal contained 5,600 ppm barlum. Rao and Smlth (1987) reported the average concentration of barium in flve coal seams of the Chuitna district, Beluga fleld, and showed that barlum content in coal ash generally decreases downsection. From youngest to oldest, the coals contained the following barlum contents: Blue Seam (15 samples), 8,473 ppm; Red 3 Seam (13 samples), 9,342 ppm; Red 2 Seam (26 samples), 6,781 ppm; Red 1 Seam (16 samples), 6,138 ppm; and Purple Seam (5 samples); 4,720 ppm.

Rao and Wolff (1981) found relatively high barium contents in Broad Pass field lignite. A Coal Creek seam showed 2,200 ppm barlum on a whole-coal basts and 11,000 ppm bartum 1n. coal ash.

Nenana province. Rao (1968) found an average barium content of 255 pom in 25 Nenana basin whole-coal samples and 2,604 ppm in ash samples of the same coals. Rao and Wolff (198I) reported a relatively high barlum content in upper Lignite (Hosanna) Creek, Jarvis Creek, and Litele Tonzona River coals. An average of six Nenana basin samples including the No. 2, No. 4, No. 6 (2 spl1ts), Moose, and Caribou seams, all of subbituminous $C$ rank, showed 932 ppm barium on a whole-coal basis and 8,283 ppm barium in coal ash. Affolter and others (1981) cited a range in barium concentration of 150 to 1,500 ppm in 20 Healy Quadrangle whole-coal samples and a geometric mean content of 500 ppm. Affolter and Stricker (1987) found an average barium content of 505 ppm for two whole-coal samples of Seam No. 3, Usibelli Mine.

Rao (1968) reported that three whole-coal samples of Jarvis Creek field seams contained an average barium content of 576 ppm; ash samples of the same coals contalned an average 6,043 ppm barium. Rao and Wolff (1981) reported that a subbitumiaous C-ranked seam from Ober Creek, Jarvis Creek fleld conta1ned 1,700 ppm barium on a whole-coal basis and 15,000 ppm barium in coal ash. Below1ch (1987) clted an average barlum concentration of $660 \mathrm{ppm}$ in 27 Jarvis Creek fleld whole-coal samples.

Alaska Peninsula province. Conwell and Triplehorn (1978) reported an average concentration of barium of 675 ppm in eight Alaska Peninsula whole-coal samples.

Gulf of Alaska province. Rao (1968) reported an average barium concentration of $111 \mathrm{pPm}$ in five Bering River fleld whole-coal samples and 4,288 ppin in ash samples of the same coals. Smith and Rao (1987) reported an average concentration of $1,850 \mathrm{ppm}$ barlum in 20 Bering River fleld coal-ash samples. 
PROFILE 5 - BERYLLIUM

Symbol: Be

Atomic number: 4

\begin{tabular}{ll} 
& \multicolumn{1}{c}{$\frac{\operatorname{Cog} 1}{10}$} \\
Alaska & $0.2-10 \mathrm{ppm}$ \\
U.S. & $0.05-330 \mathrm{ppm}$ \\
World & N.E.
\end{tabular}

Atomic welght: 9.0122

$$
\begin{gathered}
\frac{\text { Ash }}{\text { N.E. }} \\
0-1,100 \text { ppm } \\
10-1,000 \text { ppm }
\end{gathered}
$$

Beryllium is a metallic element that forms small highly charged lons (high lonic potential; Zubovic and others, 1966a,b). It is comonly assoctated with sllicate minerals. Turekian and Wedepohl (196l) reported the following average beryllium contents in common sedimentary rocks: shales, 3 ppm; sandstones, 0.X ppo; and carbonates, 0.X ppm. Orhe1m (1979) cited the following clarke values for beryllium: earth's crust, $2.8 \mathrm{ppm}$; soll, $0.8 \mathrm{ppm}$; and plant ash, $1.2 \mathrm{ppm}$. Averttt (1975) estlmated berylifum's concentration in the earth's crust at $2 \mathrm{ppm}$. It $1 \mathrm{~s}$ found as a minor element in nearly all coal beds.

Beryllium 1s present in coal ash in vastly greater concentration than its estimated average concentration in the earth's crust. It appears that there is a greater enrichment of beryllium in coals of low ash (Averitt, 1975).

Beryllium is introduced into coal at the time of peat formation, and is derlved from exoding areas of beryllium-bear1ng rocks (Averttt, 1975). Beryllium tends to be concentrated near the source areas of a coal basin (Zubov1c, 1966). It is mostly found in the vitrinitic components of coal. There is no appreclable beryllium in the inert constituents of coal (Avertte, 1975).

Beryllium is one of the elements of chlef environmental concern in coal. It is generally toxic to plant and animal life at relatively low concentrations (Ruch and others, 1974). It can be enrlched in some coals such that upon further concentration in ash or other products, may become environmentally hazardous (Altschuler and Johnston, 1976).

Berylitum is one of the elements showing greatest organic affinity; it is concentrated tn clean-coal fractions (Ruch and others, 1974). On combustion, $1 t$ is generally retalned in high-temperature agh, and over 95 percent is retalned in low-temperature ash (Ruch and others, 1974).

\section{World Coals}

Berylifum exhibits a worldwide average concentration of $3 \mathrm{ppm}$ (Swanson and others, 1976; U.S. National Combittee for Geochemistry, 1980). Berkowitz (1979) reported a maximum concentration of beryllium in coal ash of $1,000 \mathrm{gm} / \mathrm{ton}$ and an average concentration of $300 \mathrm{gm} / \mathrm{ton}$. 


\section{United States Coals}

Sharkey and others (1975) found that beryllium occurred in 100 percent of 13 U.S. raw coals analyzed, and that it ranged in concentration from 0.4 to 3 ppm. Los Alamos Sclentific Laboratory (1976) reported a range in beryllium concentration in U.S. coals at 0-31 ppm. Zubovic and others (1979) cited a range for beryllium in U.S. coals of 0.05-330 ppm. Beryllium exhibits a geometric mean in U.S. cosls of 1.4 ppm and an arithmetic mean of 2.0 Ppm (Swanson and others, 1976; Zubovic and others, 1979; and U.S. National Comittee for Geochemistry, 1980). Estlmated geometric mean beryllium contencs by rank are as follows: anthracite, $1.5 \mathrm{ppm}$; bituminous, $2.0 \mathrm{ppm}$; subbituminous $0.7 \mathrm{ppr}$; and lignite, $2.0 \mathrm{ppm}$ (Swanson and others, 1976).

Los Alamos Sclentiflc Laboratory (1976) reported a range in beryllium concentration in ashes of U.S. coals at 0 to $1,100 \mathrm{pPm}$, and estimated geometrlc mean contents by rank as follows: anthraclte, $9 \mathrm{ppm}$; low-volatile bituminous, 16 ppm; medium-volatile bituminous, 13 ppm; high volatile bituminous, $17 \mathrm{ppm}$; and subbituminous and lignite, $6 \mathrm{ppm}$.

Appalachian region. Los Alamos Sclentific Laboratory (1976) reported an average concentration of 2.5 ppm beryll1um in 73 Appalachian region wholecoal samples. Swanson and others (1976) reported a geometric mean content of 2 ppo beryllium in 331 Appalachian region whole-coal samples. Gluskoter and others (1977) reported a geometric mean content of 1.1 ppm beryllium in 23 Appalachlan whole-coal samples.

Interior reglon. Los Alamos Sclentiflc Laboratory (1976) reported a geometric mean content of $2.5 \mathrm{ppm}$ beryllium 1053 Interior reglon whole-coal samples. Swanson and others (1976) reported a geometric mean content of 1.5 ppm beryllium in 194 Interfor region cosls. Gluskoter and others (1977) reported a geometric mean content of $1.6 \mathrm{ppm}$ beryllium in 113 Illinols basin coals.

Western region. Los Alamos Scientific Laboratory (1976) reported an average concentration of 1.1 ppm beryllium in 48 Western and Souchwestern Interior U.S. whole-coal samples, and an average content of $1.5 \mathrm{ppm}$ beryllium In 51 Northern Great Pla1ns coals. Swanson and others (1976) reported a geometric mean content of 0.3 ppm beryllium in 93 Wegtern region coals and a geometric mean content of $2 \mathrm{ppm}$ beryllium in 34 Texas coals. Gluskoter and others (1977) reported a geometric mean contenc of 0.35 ppm beryli1um in 20 Wegtern U.S. coals.

\section{Alaska Coals}

There exists an abundant amount of data relating to beryllium concentrations in Alaskan coals and coal ashes. In general, compared to other U.S. coals, the content of beryllium is low in Alaskan coals.

Northern Alaska province. Rao (1968) found the concentration of beryllium in 12 Northern Alaska whole-coal samples to average $<0.8 \mathrm{ppm}$, and in ashes of the same coals, beryllium averaged $<6.2 \mathrm{ppm}$. Conwell and Triplehorn 
(1976) Found 70 ppm beryllium in a Kukpuk River coal-ash sample, and 15 ppm beryllium in a Cape Thompson coal-ash sample. Affolter and others (1981) determined a range of 0.1 to 5 ppm beryllium in 54 Utukok River Quadrangle coals and a geometric mean content of 0.3 ppm.

Cook Inlet-Susitna provirce. Rao (1968) reported an average beryllium concentration of $0.7 \mathrm{ppm}$ in 22 Matanuska Valley whole-coal samples, and ar, average content of $5.1 \mathrm{ppm}$ beryllium in ashes of the same coals. Merritt (1985b) found a mean content of 0.9 ppm berylllum in coal-ash samples of 31 Matanuska Valley coals.

Rao (1968) reported an average beryllium concentration of $<0.9$ ppm in eight Kenal fleld whole-coal samples and $<2.5 \mathrm{ppm}$ beryllium in ash-samples of the same coals. Affolter and others (1981) found a range in beryllium content of $<0.2$ to $1.5 \mathrm{ppm}$ in 10 Kenal Quadrangle whole-coal samples and a geometric mean content of $0.5 \mathrm{ppm}$; In 34 Seldovia Quadrangle coals, they reported a range in beryllium content of $<0.2$ to 1.5 ppm and a geometric mean content of $0.3 \mathrm{ppm}$. Merritt and others (1987) reported an average beryllium content of $2.3 \mathrm{ppm}$ in 31 Kenai field coal-ash samples.

Conwell (1977) reparted a range in beryllium content from 3 to $10 \mathrm{ppm}$ 1n ash samples of seven Beluga fleld coals and a mean content of 7 ppm. Based on samples of six coal beds frow the Tyonek Formation, Beluga fleld, Affolter and Stricker (1984) found that the concentration of beryllium varied directly with the ash content of the coals. Rao and Smith (1987) determined from coal seams of the Chultna distrfct, Beluga fleld, that the average concentrations of bergllium Increased downsection in coal-ash samples. By seam, they showed the following contents: Blue Seam ( 15 samples), 4.0 ppm; Red 3 Seam ( 13 amples), 4.3 ppm; Red 2 Seam (26 samples), 5.4 ppm; Red I Seam (16 samples), $7.7 \mathrm{Ppm}$; and Purple Seam (5 samples), $8.5 \mathrm{ppm}$.

Nenana province. Rao (1968) clted an average beryllium content of $<0.3 \mathrm{ppm}$ in 25 whole-coal samples of the Nenana basin; the average in ash samples of the same coals was <2.5 ppm. In three Jarvis Creek fleld raw coal samples, Rao (1968) found an average berylilum concentration of $<0.3 \mathrm{ppm}$, and In ash samples of the same three coals, he found an average beryllium content of $2.6 \mathrm{ppm}$. Affolter and others (1981) found a range in beryllium content of < 0.2 to 3.0 ppro in 20 Healy Quadrangle whole-coal samples and a geometric mean content of 0.2 ppm. Affolter and Stricker (1987) found an average beryllium concentration of $0.19 \mathrm{ppm}$ in two whole-coal samples of the No. 3 Seam, Usibell1 Mine. Belowich (1987) reported an average beryllium content of 0.7 ppm in 27 Jarvis Creek field whole-coal samples. Merritt (1985b) cited a general factor of enrichment for berylilum of $1.4 \mathrm{X}$ based on its content in Nenana basin coal-ash samples.

Gulf of Alaska province. Rao (1968) reported an average beryllium concentration of <0.2 ppr in flve Bering River field whole-coal samples; ash samples of the same coals showed an average beryllium content of $<3.8 \mathrm{ppm}$. Smith and Rao (1987) found an average beryllium concentration of 10.5 ppu in ash samples of 20 Bering River field coals. 


$$
\text { PROFILE } 6 \text { - BISMUTH }
$$

Symbol: 81

Atomic number: 83

Atomic weight: 208.980

$\begin{array}{lcc} & \frac{C o a l}{N . E .} & \frac{A s h}{N . E} \\ \text { Alaska } & <0.1-1 \mathrm{ppm} & 1-900 \mathrm{ppm} \\ \text { U.S. } & 0.1-10 \mathrm{ppm} & 1-500 \mathrm{Ppm} \\ \text { World } & \end{array}$

Bismuth is a highly diamagnetic metallic element used to form various alloys. It occurs in coal in appreclably greater concentration than its escimated average concentration in the earth's crust (Averitt, 1975).

\section{World Coals}

Berkowltz (1979) reported a maximum bismuth concentration in coal ash of $200 \mathrm{gm} / t 00$ and an average concentracton of $20 \mathrm{gm} /$ ton. The U.S. National Comittee for Geochemistry (1980) clted a worldwide average bismuth concentration in coal of 5.5 ppm.

\section{United States Coals}

Sharkey and others (1975) found that blsmuth occurred in only 31 percent of 13 U.S. raw coals analyzed, and that 1t ranged in concentration in these coals from $<0.1$ to $0.2 \mathrm{ppm}$. 81swuth content in U.S. coal ashes ranges from 1 to $900 \mathrm{pPm}$ (Los Alamos Sclentiflc Laboratory, 1976). The U.S. average concentration of bismuth is $0.7 \mathrm{ppm}$ on a whole-coal basts (U.S. Natloagl Compltcee for Geochemistry, 1980).

\section{Alaska Corls}

B1smuth was not detected in ash samples of Xukpuk River and Cape Thompson coals from northern Alaska (Conwell and Triplehorn, 1976). 


$$
\text { PROETLE } 7 \text { - BORON }
$$

Symbol: B
Atoric number: 5

$$
\begin{aligned}
& 5-300 \text { Ppm } \\
& 1-400 \text { Ppm } \\
& 1-500 \text { ppm }
\end{aligned}
$$

Atomic welght: 10.811

$$
\begin{gathered}
\frac{\text { Ash }}{90-4,000} \text { ррш } \\
25-7,000 \text { ppm } \\
10-3,000 \text { ppm }
\end{gathered}
$$

Boron is a semi-metal that forms small highly charged ions (that is, exhiblts high tonic potential). It is assoclated with complex aluminumsilicate minerals as illite and courmaline. It is one of the elements showing greatest organic affinity, and tends to be concentrated in clean coal fractions (Ruch and others, 1974). Some boron In coal was derived Erom original plant canstituents (Averitt, 1961). Boron's concentration 1n coals may be the result of greater marine influence during and following coal-swamp development (Gluskoter and others, 1977). It tends to be concentrated near the source areas of a coal basin (Zubovic and others, 1966a) and 1n surface and rear-surface solls supporting the growth of plants (Averitt, 1975 ). Boron is retalned in high-temperature ash (Ruch and others, 1974). Excessive boron makes a coal unsuitable for the production of reactor graphite (Stach and others, 1982).

Boron is present in coal ash in concentrations significantly greater than 1ts clarke value (Gluskorer and others, 1977). It shows a moderate enrichment factor of $5 X$ in coal compared to lts average concentration in the earth's crust (U.S. National Combltee for Geochemistry, 1980). Turekian and Wedepohl (1961) reported the following average boron concentrations in common sedimentary rocks: shales, 100 ppm; sandstones, 35 ppm; and carbonates, 20 ppm. Orhelm (1979) reported the following clarke values for borod: earth's crust, 10 ppm; soll, 10 ppm; plant ash, 700 ppm; and water, 4.6 ppm.

$$
\text { World Coals }
$$

The U.S. National Commitce for Geochemistry (1980) reported an average worldwide content of boron in whole coal samples of 85 ppm. Berkowitz (1979) reported a maximum concentration of boron in coal ash of 3,000 gm/ton, and an average concentration of $600 \mathrm{gm} / \mathrm{ton}$.

\section{United States Coals}

Sharkey and others (1975) found that boron occurred in 100 percent of 13 U.S. raw coals analyzed, and that 1 t ranged in concentration from 1 to $230 \mathrm{ppm}$. Others have reported a range in boron conteat from 1.2 to $356 \mathrm{ppm}$ In U.S. whole-coal samples (Los Alawos Sclentific Laboratory, 1976). Swanson and others (1976) reported an average concentration of 60 ppin in $601 \mathrm{U} . S$. whole-coal samples, and the U.S. National Commttee for Geochemistry (1980) reported an average concentration of $50 \mathrm{ppm}$. 
Los Alamos Scientific Laboratory (1976) cited a range of 30 to 6,500 ppm boron in U.S. coal-ash samples, and also gave mean concentrations of boron in ashes of U.S. coals of various rank as follows: snthrac1te, $90 \mathrm{ppm}$; lowvolatile bituminous, $123 \mathrm{ppm}$; medtum-volatile bltuminous, $218 \mathrm{ppm}$; highvolatile bituminous, $770 \mathrm{ppm}$; and subbituminous and lignite, 1,010 ppm.

Appalachian region. Los Alamos Selentific Laboratory (1976) reported an average concentration of $25 \mathrm{ppm}$ boron in 73 Appalachian region whole-coal samples. Swanson and others (1976) reported a geometric mean content of $20 \mathrm{ppm}$ boron in 331 Appalachian region whole-coal samples. Gluskoter and others (1977) reported a geometric mean content of $28 \mathrm{ppm}$ boron in 23 Appalachian region coals.

Intertor region. Los Alamos Sctentific Laboratory (1976) reported an average concentration of 96 ppm boron in 53 Interior region whole-coal samples. Swanson and others (1976) reported a geometric mean content of 50 ppm boron in 194 Interior region coals. Gluskoter and others (1977) reported a geometric mean content of $98 \mathrm{ppm}$ boron in 99 Interior region coals.

Western region. Los Alamos Scientific Laboratory (1976) reported an average concentration of 33 ppm boron in 48 Western and Southwestern Interlor U.S. whole coal samples, and an average content of 116 ppm boron in 51 Northern Great Plalns coals. Swanson and others (1976) reported a geometrlc mean content of $70 \mathrm{ppm}$ boron in 93 Western region coals and a geometric mean content of 100 ppm boron in 34 Texas coals. Gluskoter and others (1977) reported a geometric mean content of $48 \mathrm{ppm}$ boron in 27 Western region coals.

\section{Alaska Coals}

There exists an abundant amount of data relating to boron concentrations in Alaskan coals and coal-ashes. In general, compared to other U.S. coals, the content of boron in Alaska tends to be lower.

Northern Alaska province. Rao (1980) found the concentration of boron in Cape Beaufort region coals to be within the range of other U.S. coals; he deterwined a range of 26 to $181 \mathrm{ppm}$ boron in 38 whole-coal samples and a mean content of $76 \mathrm{pPm}$. Rao and Wolff (1981), though, Eound 'anomalously high' concentrations of boron in two Cretaceous coals from northern Alaska. A subbltuminous B seam from the Walnwright area had a mean concentration of 250 ppm boron, and a high-volatile bituminous coal from Sagwon Bluffs had a mean content of $110 \mathrm{ppm}$ boron. Affolter and others (1981) determined a range of 20 to 100 ppm boron 1n 43 Utukok River Quadrangle coals and a geometric mean content of $50 \mathrm{ppm}$.

Conwell and Trtplehorn (1976) found 300 ppm boron th a Rokuk River coal-ash sample, and 200 ppm in a Cape Thompson coa1-ash sample. Rao (1980) reported a range of 96 to 2,500 ppm boron in ashes of 38 Cape Beaufort region coals and a mean content of $446 \mathrm{ppm}$. In the ash of the Wainwright subbltuminous 8 coal, Rao and Wolff (1981) found a boron concentration of $4,100 \mathrm{ppm}$, and in the ash of the Sagwon Bluffs high-volatile $C$ bituminous coal they found a boron content of 180 ppm. 
Cook Inlet-Susitna province. Rao and Wolfe (1981) reported a boron content of $20 \mathrm{ppm} 1 \mathrm{n}$ the lower seam (hvb), Castle Mountalo Mine, Matanuska field, and 72 ppm in a Premier Mine seam (hvb rank), Matanuska field. Coalash samples of the same two coals showed boron concentrations of $110 \mathrm{ppm}$ and $470 \mathrm{ppm}$, respectively. Merrtte (1985b) found a mean content of $75 \mathrm{ppm}$ in coal-ash samples of 31 Matanuska field coals.

In the Kenal field, Rao and Wolff (1981) reported a boron content of $43 \mathrm{ppm}$ in a whole-coal sample of subbituminous C Cabin bed; they reported a boron concentration of $380 \mathrm{ppm}$ in an ash sample of the same coal. Affolter and others (1981) found a range in boron content of 10 to $70 \mathrm{ppm}$ in 10 Kena1 Quadrangle coals and a geometric mean content of $20 \mathrm{ppm}$; in 34 Seldovia Quadrangle coals, they reported a range in boron content of 5 to 70 ppw and a geometric mean content of $20 \mathrm{ppm}$.

Rao and Wolff (1981) reported a boron concentration of 13 ppm for a whole-coal sample of the subbltuminous $C$ Waterfall Seam of the Beluga fleld. They found a boron content of $14 \mathrm{ppm}$ in a whole-coal sample of a sunflower Creek, Yentna field lignite seam. Ash samples of the same two coals revealed boron concentrations of $130 \mathrm{ppm}$ and $345 \mathrm{ppm}$, respectively. Conwell (1977) reported a range of 50 to $300 \mathrm{ppm}$ in ash samples of seven Beluga field coals and a mean content of $127 \mathrm{ppm}$. Merritt (1987) found a range in boron content of $<10$ to 55 ppm in 66 Susitna lowland samples and an average content of $<54 \mathrm{ppm}$. In a Coal Creek, Broad Pass fleld 11gnite, Rao and Wolff (1981) reported a whole-coal boron concentration of $19 \mathrm{ppm}$ and an ash concentration of $96 \mathrm{ppm}$.

Nenana province. Rao and Wolff (1981) found anomalously high concentrations of boron'in two Nenana basin samples. They analyzed six whole-coal samples Including Seam Nos. 2, 4, and 6 (3 splits) and the Cartbou Seam, all of subbituminous C rank; they reported a mean boron concentration of $59 \mathrm{ppm}$. Affolter and Stricker (1987) found an average boron concentration of 24 ppm in two whole-coal samples of the No. 3 Seam, Usibelli Mine. They reported a range of 15 to $100 \mathrm{ppm}$ in 20 Healy Quadrangle whole-coal samples and a geowetric mean content of $30 \mathrm{ppm}$. Rao and Wolff (1981) reported a boron concentration of $15 \mathrm{ppm}$ in an Ober Creek, Jarvis Creek fleld whole-coal sample, and a boron content of $45 \mathrm{ppr}$ in a subbituminous $C$ coal sample of the main seam, Little Tonzona River field.

Merritt (1985a) reported a general factor of enrichment of $55 \mathrm{X}$ for borou in Nenana basin coal-ash samples. Rao and Wolff (1981) found an average boron concentration of 467 ppm in ash samples of six Nenana basin subbituminous $C$ coals, including Seam Nos. 2, 4, and 6 ( 3 splita) and the Cartbou Seam. The mean content of boron in the ash of the Ober Creek, Jarvis Creek fleld subbituminous $C$ coal was $130 \mathrm{ppm}$. An ash sample of the main seam (sub C rank) Little Tonzona Rlver fleld, revealed a boron concentration of $330 \mathrm{ppm}$ (Rao and Wolff, 1981).

Alaska Peninsula province. Conwell and Triplehorn (1978) found an average boron concentration of $255 \mathrm{ppw}$ in eight ash samples of coals from the Herendeen Bay and Chignik flelds. 
Yukon-Koyukuk province. Rao and Wolff (1981) reported a boron content of 280 ppm In a whole-coal sample of the main seam (hvb rank), Tramway Bar field. An ash sample of the same coal had a boron content of $670 \mathrm{ppm}$. 


$$
\text { PROFILE } 8 \text { - BROMINE }
$$

Symbol: Br

Atomic weight: 79.909

\begin{tabular}{lll} 
& \multicolumn{1}{c}{ Coa 1} & Ash \\
Alaska & \multicolumn{1}{c}{ N.E. } & N.E. \\
U.S. & $0.5-60 \mathrm{ppm}$ & N.E. \\
World & $0.1-100 \mathrm{ppra}$ & N.E.
\end{tabular}

Bromine is a volatile nonmetallic element with 100 percent being lost during low-temperature ashing (Ruch and others, 1974). Tureklan and Wedepohl (1961) reported the following bromine concentrations in common sedinentary rocks: shales, 4 ppm; sandstones, 1 ppm; and carbonates, 6.2 ppm.

\section{World Coals}

Abemethy and Gibson (1963) reported an average bromine content in coal of $3.7 \mathrm{ppm}$.

\section{Uniced States Coals}

Sharkey and others (1975) found that bromine occurred in 100 percent of 13 U.S. raw coals analyzed, and that it ranged in concentration from 1 to $23 \mathrm{ppm}$. Others have cited a range in bromine content in U.S. coals from 4 to S2 ppm (Los Alamos Scleatific Laboratory, 1976). The U.S. average concentration of bromine in coal is 2.6 ppo according to the U.S. National Committee for Geochemistry (1980).

Appalachian region. Gluskoter and others (1977) reported a geometric mean bromine content of $8.9 \mathrm{ppm}$ In 23 Appalachian region whole-cosi samples.

Interior region. Gluskoter and others (1977) reported a geometric mean bromine content of $10 \mathrm{pPm}$ in 113 IIlinois basin whole-coal samples.

Western regton. Gluskoter and others (1977) reported a geometric mean bromine content of $2.1 \mathrm{ppm}$ in 29 western U.S. whole-coal samples.

\section{Alaska Coals}

Merrttt (1985b) reported a mean bromine content of 27 ppm in ash samples of 30 Mantanuska Valley coals. 


$\begin{array}{ll} & \frac{\text { Coal }}{-1 \text { ppm }} \\ \text { Alaska } & .05-5 . \\ \text { U.S. } & 0.01-65 \text { PPm } \\ \text { World } & \text { N.E. }\end{array}$

$$
\begin{aligned}
& <1-\frac{\text { Ash }}{30} \mathrm{ppm} \\
& \text { N.E. } \\
& 1-100 \text { ppm }
\end{aligned}
$$

Cadmium is a metallic element that occurs chiefly in ores of ziac, copper, and lead. It is most typlcally assoclated with the sulfide mineral group, espectally sphalerite-- $(\mathrm{Zn}, \mathrm{Cd}) \mathrm{S}$. Tureklan and Wedepohl (1961) reported the following average cadmium contents in common sedimentary rocks: shales, $0.3 \mathrm{ppt}$, sandstones, $0.0 \mathrm{Xpm}$, and carbonates, $0.035 \mathrm{ppm}$. Orheim (1979) reported the following clarke values for cadmium: earth's crust, $0.2 \mathrm{ppm}$; so11, $0.5 \mathrm{ppm}$; plant ash, $0.1 \mathrm{ppm}$, and water, $0.0001 \mathrm{ppm}$. Cadmium shows a moderate enrichment factor in coal ash of $6.5 \mathrm{X}$ compared to its average estimated composition in the earth's crust (U.S. National Committee for Geocheuistry, 1980).

Cadmium is one of the elements of chief environmental concern in coal; it is generally toxic to plant and animal life at relatively low concentratlons (Ruch and others, 1974). Cadmium can be enrlched in some coals such that upon Eurther concentration in ash or other products, it may become environmentally hazardous (Altschuler and Johnston, 1976).

Cadmium is generally inorganically combined in coal and 18 one of the elements showing least organic affinity (Ruch and others, 1974). It tends to be concentrated in the mineral matter or heavier spectflc gravity fraction of coal (Cavallaro and others, 1978).

Cadmium can be released from coal-combustion sources and enriched on the surfaces of fly-ash particles Erom coal-Eired plants (Mraw and others, 1983). It is generally retained in high-cemperature ash and over 90 percent is retained in low-temperature ash (Ruch and others, 1974).

\section{Whole Coals}

Abernethy and Gibson (1963) reported an average cadmium content in cos 1 of 0.47 ppm. Berkowitz (1979) cited a maximum concentration of cadmium in coal ash of $50 \mathrm{gm} /$ ton and an average concentration of $5 \mathrm{gm} / \mathrm{ton}$.

\section{Unfed States Coals}

Sharkey and others (1975) Eound that cadmlum occurred in 92 percent of 13 U.S, raw coals analyzed, and that 1t ranged in concentration from $<0.01$ to $0.7 \mathrm{ppm}$. Others have reported a range in cadmium content from 0.1 to 65 ppm in U.S. coeis (Los Alamos Scientiflc Laboratory, 1976; Wewerka and others, 1976). Swanson and others (1976) found a geometric mean cadmium content of 0.2 ppm 1n 601 U.S. whole-coal samples. The U.S. National Comittee for Gecchemistry (1980) cited a U.S. average cadmium concentracion of 1.3 ppm. 
Appalachian region. Swanson and others (1976) reported a geonetr1c mean content of 0.3 ppm cadmium in 331 Appalachian region whole-coal samples. Gluskoter and others (1977) reported a geometric mean content of 0.19 ppm cadmium in 23 Appalachian region coals.

Interior region. Swanson and others (1976) reported a geometric mean content of $0.12 \mathrm{ppm}$ cadmium in 194 Interior region whole-coal samples. Gluskoter and others (1977) reported a geometric mean content of 0.59 ppm cadmium in 93 Illinols basin whole-coal samples.

Western region. Swanson and others (1976) reported a geometric mean content of $0.2 \mathrm{ppm}$ cadmium in 93 Western U.S. region coals and a geometric mean content of 0.2 ppm cadmium in 34 Texas coals. Gluskoter and others (1977) reported a geomerric mean content of 0.15 ppm cadmium in 29 Western U.S. coals.

\section{Alaska Coals}

Northern Alaska province. Conwell and Triplehorn (1976) found an average concentration of $1.5 \mathrm{ppm}$ cadmium in a Kukpuk River coal-ash sample and $<1.0$ ppm cadmium in a Cape Thompson coal-ash sample.

Cook Inlet-Susitna province. Merritt (1985b) found a mean concentration of 1.9 ppm cadmium in 29 Matanuska Valley coal-ash samples. Merritt and others (1987) reported an average cadmium content of <10 ppm in 31 Kenal field coal-ash samples. Conwell (1977) reported a cadmium content of < 1 ppm in seven Beluga fleld coal-ash samples. Merritt (1987a) reported a range in cadrium content of <l to 27 ppm and an average content <7 ppm in 45 Susitna lowland coal-ash samples.

Nenana province. Affolter and others (1981) clted a range in cadmium concentration of $<0.06$ to $0.56 \mathrm{ppm}$ in 20 Healy Quadrangle whole-coal samples and a geometric mean content of $0.07 \mathrm{ppm}$. Affolter and Stricker (1987) found an average cadmium concentration of 0.010 ppa for two whole-coal samples of Seam No. 3, Usibelli Mine. Belowich (1987) reported an average cadmium content of < 1 ppm in 27 Jarvis Creek field whole-coal samples. Merritt (1985a) reported a general factor of enrichment of $5.5 \mathrm{X}$ for cadmium concentration in Nenana basin coal-ash samples.

Alaska Peninsula province. Conwell and Trlplehorn (1978) reported an average concentration of $<1$ ppm cadmium in elght Alaska Peninsula cozl-ash samples. 


\section{PROFILE 10 - CALCIUM}

Symbol: $\mathrm{Ca}$

Atomic number: 20

Atom1c welght: 40.08

$\begin{array}{lc}\text { Alaska } & \text { Coal } \\ \text { U.S. } & 100-\frac{27,000}{\mathrm{ppm}} \\ \text { World } & 100-38,000 \mathrm{ppm} \\ & 100-40,000 \mathrm{ppm}\end{array}$

Calclum is a metallic element composing approximately 3 percent of the earth's crust. It is mainly assoclated with the carbonate and sulfate mineral groups, and occurs naturally as calcite or limestone $\left(\mathrm{CaCO}_{3}\right)$, gypsum $\left(\mathrm{CaSO}_{4} \cdot 2 \mathrm{H}_{2} \mathrm{O}\right)$, and flourtte $\left(\mathrm{CaF}_{2}\right)$. Turekian and Wedepohl (1961) reported the following average calclum contents in common sedinentary rocks: shales, 22,100 ppm; sandstones, 39,100 ppm; and carbonates, 302,300 ppm. Calcium 1s a major inorganic element in the mineral constituents of coal, and calctum oxide forms a signiflcant part of coal ash. Calclum has an 1mportant effect on the use of coal in combustion and cokemaking.

\section{World Coals}

Abemethy and Gibson (1963) reported an average calcium content in coal of 4,340 ppm. The U.S. National Comitree for Geochemistry (1980) reported a worldwide average calcium concentration in coal of 1.0 percent.

\section{United States Coals}

Sharkey and others (1975) Eound that calcium occurred in 100 percent of 13 U.S. raw coals analyzed, and that 1 ranged in concentration from 800 to $6,100 \mathrm{ppm}$. Others have cited a range in calclum content from 0.05 to 2.67 percent in U.S. coals (Los Alamos Sclentific Laboratary, 1976; Wewerka and others, 1976). Swanson and others (1976) reported a geometric mean calclum content in 601 U.S. coals of 0.5 percent. The U.S. National Comittee for Geochemistry (1980) c1ted an average U.S. Calclum concentration In cosl of 0.54 percent. Calclum varles from 0.58 to 14 percent in ashes of U.S. coals (Los Alamos Sclentific Laboratory, 1976).

Appalachian region. Swanson and others (1976) reported a geometric mean content of 0.093 percent calcium in 331 Appalachlan region whole-coal samples. Gluskoter and others (1977) reported a geometric mean content of 0.34 percent calcium in 23 Appalachian whole-coal samples.

Interior region. Swanson and others (1976) reported a geometric mean content of 0.5 percent $c a 1 c t u m$ in 194 Interior region whole-coal samples. Gluskoter and others (1977) reported a geometric mean content of 0.51 percent calcium in 113 Illinois basin whole-coal samples.

Western region. Swanson and others (1976) reported a geometric mean content of 0.92 percent calclum 1 n 93 Western U.S. reglon coals and a geometric mean content of 0.6 percent calcium in 34 Texas coals. Gluskoter 
and others (1977) reported a geometric mean content of 1.5 percent calcium in 29 Western U.S. coals.

\section{Alaska Coals}

Affolter and others (1981) reported geonetric mean calcium concentrations of 1.3 percent, 0.70 percent, 1.2 percent, and 0.40 percent in wholecoal samples of the healy (20), Kenai (10), Seldovia (34), and Utukok River (24) Quadrangles, respectively. Compared to 410 Powder River region coal samples, the contents of calcium in coals of the Healy and Seldovia Quadrangles were significantly higher, the content of calcium in Kenai Quadrangle coals was significantly lower. Compared to 295 coal samples of the Rocky Mouncain province, the content of calctum in Utukok River Quadrangle coals was not significantly different. 


\section{PROFILE 11 - CARBON}

Symbol: C

Atomic number: 6

Atomic we1ght: 12.01115

$\begin{array}{lll} & \text { Coal } & \text { Ash } \\ \text { Alaska } & 350,000-\frac{730,000}{\mathrm{ppm}} & \\ \text { U.S. } & 380,000-800,000 \mathrm{ppm} & -- \\ \text { World } & 350,000-850,000 \mathrm{ppm} & --\end{array}$

Carbon is a naturally abundant nonmetallic element that occurs in a11 organlc and many 1norganlc compounds. It belongs to the organlc mineral group of elements (Wewerka and others, 1978). Carbon is one of the major elements composing the basic structure of coal, and it generally increases in content with rank.

Gluskoter and others (1977) reported a geometric mean carbon content of 70 percent for 110 Illinols basin whole-coal samples, 72 percent for 22 Appalachlan whole-coal samples, and 67 percent for 29 Wegtern U.S. whole-coal samples.

Alaskan coals are similar in carbon composition to other U.S. coals when considered by rank. For example, a high-volatile A bituminous coal from the Matanuska Valley contalns about 70 percent carbon, whereas Nenana and Beluga subbituminous coals contain 47 percent carbon (equilibrium bed molsture basis). 
PROEILE 12 - CERIUM

Symbol: $\mathrm{Ce}$

Atomic number: 58

$\begin{array}{lr} & \text { Coal } \\ \text { Alaska } & \text { N.E. } \\ \text { U.S. } & 1-50 \text { ppm } \\ \text { World } & \text { N.E. }\end{array}$

Atomic weight: 140.12

10-7 $\frac{\text { Ash }}{00 \text { ppo }}$
N.E.
N.E.

Cerfum is a metallic, rare-earth element that occurs chlefly in the mineral monazite $\{(\mathrm{Ce}, \mathrm{La}, \mathrm{Y}, \mathrm{Th}) \mathrm{PO}\}$ and used in varlous metallurglcal applications. It is an element generally associated with silicate minerals. Turekian and Wedepohl (1961) reported the following average cerium concentratlons in common sedimentary rocks: shales, 59 ppm; sandstones, $92 \mathrm{ppm}$; and carbonates, 11.5 ppu. Abernethy and Glbson (1963) found an average cerium content in coal of 8.2 ppm. The U.S. National Committee for Geochemistry (1980) cited a worldwide average cerium concentration in coal of $11.5 \mathrm{ppm}$.

Sharkey and others (1975) found that cerium occurred in 100 percent of 13 U.S. raw coals analyzed, and that it ranged in concentration from 1 to 30 PPm. U.S. coals contain an average cerlum content of $7.7 \mathrm{ppm}$; a typlcal U.S. subbituminous coal contains 5.5 ppm cerlum, and a cypical U.S. lignite contains 12.3 ppm cerium (U.S. National Committee for Geochemistry, 1980).

Gluskoter and others (1977) reported a geometric mean cerium content of 23 ppa for 14 Appalachtan region whole-coal samples, 12 ppm for 56 IIlinols bastn whole-coal samples, and 22 ppm cerium for 22 Western U.S. whole-coal samples.

Conwell and Triplehorn (1976) Eound 700 ppm cerium in an ash sample of a Rukpuk River, northern Alaska coal. Merritt (1985b) reported a mean cerium concentration of 29 ppm in ash samples of 31 Matanuska Valley coals. Affolter and Stricker (1987) cited an average cerlum content of 10 ppm for two whole-coal samples of Seam No. 3 , Usibelli Mine. 
PROFILE 13 - CESIUM

Symbal: Cs

Atomic number: 55

Atomlc welght:

132.905

$\begin{array}{lcc} & \frac{C o a 1}{N . E .} & \text { Ash } \\ \text { Alaska } & \frac{N}{N . E .} \\ \text { U.S. } & 0.02-10 \text { Ppm } & \text { N.E. } \\ \text { Worid } & \text { N.E. } & \text { N.E. }\end{array}$

Cesium is a highly electropositive and alkaline element capable of catalyzing the hydrogenation of some organic compounds. Average cesium concentrations in coumon sedimentary rocks are $5 \mathrm{ppm}$ in shales, $0 . X \mathrm{ppm}$ 1n sandstones, and $0 . X \mathrm{ppm}$ in carbonates (Turekian and Wedepohl, 1961). Abernethy and Glbson (1963) found an average ceslum content in coal of 1.1 ppm. U.S. coals contain an average ceslum content of 0.4 ppm (U.S. National Committee for Geochemistry, 1980).

Sharkey and others (1975) found that cesium occurred in 100 percent of 13 U.S. raw coals analyzed, and that it ranged in concentration from 0.2 to 9 ppm. Gluskoter and others (1977) reported a geometric mean cesium content of 1.6 ppm in 14 Appalachian region whole-coal samples, $1.2 \mathrm{ppm}$ cesium in 56 Illinots basin whole-coal samples, and $0.16 \mathrm{ppm}$ cestum in 22 Western U.S. whole-coal samples.

Merritt (1985b) found a mean cestum contedt of $4.0 \mathrm{ppm}$ in ash samples of 25 Matanuska Valley coals. 
PROFILE 14 - CHLORINE

Symbo1: $\mathrm{Cl}$

Arom1c number: 17

Atomic weight: 35.453

$\begin{array}{lcc} & \frac{\text { Coal }}{\mathrm{N} . \mathrm{E} .} & \frac{\text { Ash }}{2,000} \mathrm{pPm} \\ \text { Alaska } & 100-8,000 \mathrm{PPm} & \text { N.E. } \\ \text { U.S. } & \text { N.E. } & \text { N.E. } \\ \text { World } & & \end{array}$

Chlorine is a gaseous element, the most abundsnt halogen. It is capable of combining with nearly all other elements, although tt is classifled in the organic mfneral group of trace elements (Wewerka and others, 1978). It has important effects on the use of coal in combustion and cokemaking.

Chlorine is generally present in coal in concentrations significanty greater than 1ts clarke value (Gluskoter and others, 1977). Tureklan and Wedepohl (1961) reported the following average chlorine concentrations in common sedimentary rocks: shales, $180 \mathrm{ppm}$; sandstones, $10 \mathrm{ppm}$; and carbonates, $150 \mathrm{ppm}$.

Abernethy and Gibson (1963) found an average chlorine content of 914 ppm in coal. The U.S. National Comittee for Geochemistry (1980) reported an average worldwide concentration of 1,000 ppm chlorine in coal.

Sharkey and others (1975) found that chlorine occurred in 100 percent of 13 U.S. raw coals analyzed, and that it ranged in concentration from 10 to 1,500 ppa. Los Alamos Sclentific Laboratory (1976) cited a range in concentration of 0 to 0.56 percent chlorine in U.S. coals. The U.S. National Committee for Geochemistry (1980) gave an average chlorine concentration of 207 ppo in U.S. coal.

Glugkoter and others (1977) reported a geowetric mean chlorine content of 0.10 percent in 23 Appalachlan region whole-coal samples, 0.08 percent in 113 Illinols basin whole-coal samples, and 0.02 percent in 29 western U.S. whole-coal samples.

Conwell and Triplehorn (1976) Found an average $0.20 \mathrm{ppm}$ chlorine in two whole-coal samples from Rukpuk R1ver and Cape Thompson, northern Alaska. Conwell (1977) reported a mesn chlorine content of $2,000 \mathrm{ppm}$ in seven Beluga fleld coal-ash samples. Merritt (1985b) reported a mean chlorine concentration of $46 \mathrm{ppm}$ in 18 Matanuska Valley coal-ash samples. 


$\begin{array}{lc} & \frac{\text { Coal }}{\text { Alaska }} \\ \text { U.S. } & 1-100 \text { Ppm } \\ \text { World } & 0-700 \text { Ppm } \\ & \text { N.E. }\end{array}$

$$
\begin{aligned}
& \text { Ash } \\
& 80-4 \overline{00} \mathrm{ppm} \\
& 0-2,000 \mathrm{ppm} \\
& 15-1,500 \mathrm{ppm}
\end{aligned}
$$

Chromlum is a metalifc element found principally in chromite ( $\mathrm{FeCr}_{2} \mathrm{O}_{4}$ ) and associated with slificate minerals. It is used as a catalyst and Eo harden steel alloys. Turekion and Wedepohl (1961) reported the following average chromtum concentrations in common sedimentary rocks: shales, 90 ppm; sandstones, 35 ppm; and carbonates, 11 pPm. Orhe1m (1979) cited the followlng clarke values for chromlum: earth's crust, 100 ppm; so11, 200 ppm; plant ash, $9 \mathrm{ppm}$; and water, $0.00005 \mathrm{ppm}$.

Chromlum generally occurs in coal in lower concentration than 1 ts estimated average concentration in the earth's crust (Averttt, 1975). Chromium is associated with both the organic and inorganic fractions of coal; it tends to be more closely allied or concentrated in the heavier spectflc gravity, inorganlc fractions (Ruch and others, 1974; Cavallaro and others, 1978). Chronlum is generally retained in high-temperature ash, and over 95 percent 1s retained in low-temperature ash (Ruch and others, 1974). It can be enriched on the surfaces of fly-ash particles from coal-fired plants (Mraw and others, 1983).

\section{World Coals}

Abernethy and Gibson (1963) cited an average chromium content in coal of 18 ppm. The U.S. National Comittee for Geochemistry (1980) noted a worldwide average chromium content in coal of $10 \mathrm{ppm}$.

\section{United States Coals}

Sharkey and others (1975) found that chromium occurred in 100 percent of 13 U.S. raw coals analyzed, and that it ranged in concentration from 26 to $400 \mathrm{ppm}$. Others have c1ted a range in chromium content from 0 to $610 \mathrm{ppm}$ in U.S. coals (Los Alamos Sclentiflc Laboratory, 1976). Swanson and ochers (1976) Found a geometric mean chromium content of 10.7 ppm in $601 \mathrm{U} . S$. coals. The U.S. Natlonal Commltee for Geochemistry (1980) reported an average concentration in coal of 15 ppm.

Chromium concentration in ashes of U.S. coals ranges from $<1$ to $1,800 \mathrm{ppm}$ and averages $304 \mathrm{ppm}$. Average chromlum contents in ashes of various ranks of coal are as follows: anthracites, 304 ppor; low-volatile bltuminous coals, 221 ppm; medium-volatile bltuminous coals, 169 ppm; high-volatile bituminous coals, 193 Ppm; subbltuminous coals and lignites, 54 ppm (Los Alamos Scientific Laboratory, 1976). 
Appalachian region. Los Alamos Sclentiflc Laboratory (1976) reported an average concentration of $13 \mathrm{ppm}$ chromium in 73 Appalachian reglon whole-coal samples. Swanson and others (1976) reported a geometric mean content of 15 ppm chromium in 331 Appalachian region whole-coal samples. Cluskoter and others (1977) reported a geometrlc mean content of 18 ppo chromiun in 23 Appalachtan region whole-coal samples.

Interior region. Los Alamos Scientific Laboratory (1976) reported an average concentration of $20 \mathrm{pPm}$ chromium in 53 Incerior region whole-coal samples. Swanson and others (1976) reported a geometric mean content of $10 \mathrm{ppm}$ chromium in 194 Interior region whole-coal samples. Gluskoter and others (1977) reported a geometric mean content of 16 ppw chromium in 113 Illtnois basin coals.

Western region. Los Alamos Sclentifle Laboratory (1976) reported an average concentration of $13 \mathrm{ppm}$ chromlum in 48 Western and Southwestern Interior reglon whole-coal samples, and an average content of 7 ppm chromium in 51 Northern Great Plalns coals. Swanson and others (1976) reported a geometric mean content of 3 ppm in 93 Western region coals and a geometric mean content of IS ppm chromium in 34 Texas coals. Gluskoter and others (1977) reported a geometric mean content of 8.1 ppm chromium in 29 Wegtern U.S. whole-coal samples.

\section{Alaska Coals}

Thexe exists an abundant amount of data relating to chromlum concentratlons in Alaskan coals and coal ashes. In general, compared to other U.S. coals, the content of chromium in Alaska coals tends to be higher.

Northern Alaska province. Rao (1968) reported an average concentration of 4.0 ppm chromium in 12 Northern Alaska whole-coal samples; ash samples of the same coals contalned an average $43 \mathrm{ppm}$ chromium. Conwell and Triplehorn (1976) Found an average content of 500 ppm chromlum in a Kukpuk River coalash sample and 300 ppm chromium in a Cape Thompson coal-ash sample. Rao (1980) analyzed and reported on chromium concentrations in some 38 Cape Beaufort region whole-coal and coal-ash samples. Although certain of the Cape Beaufort region samples showed a high concentration of chromium, 1ts average concentration was quite low compared to other U.S. coals. In raw coals, chromium ranged from 4 to $79 \mathrm{ppm}$ and had a mean content < 15 ppm; in coal-ash samples, chromlum ranged from $<30$ ppm to 157 ppm and had a mean content <54 ppm (Rao, 1980). Rao and Wolff (1981) found $3.5 \mathrm{ppm}$ chromium in a whole-coal sample of a subbituminous B seam from Meade River, northern Alaska; ash of the same sample contalned 81 ppm chromium. They reported a whole-coal chromium content of $95 \mathrm{ppm}$ in a high-volatile bituminous seam from Sagwon Bluffs, northern Alaska; ash of the same sample contalned 150 ppo chromium. Affolter and others (1981) reported a range in chromium concentration of I to 100 ppm for 54 Utukok Rlver Quadrangle whole-coal samples and a geometric mean content of $7 \mathrm{ppm}$.

Cook Inlet-Susitna province. Rao (1968) reported an average chromium content of $13.8 \mathrm{ppm}$ in 22 Matanuska Valley whole-coal samples and an average content of 80 ppri in ash samples of the same coals. Rao and Wolff (1981) 
found a chromium content of $20 \mathrm{ppm}$ in a whole-coal sample of the highvolatile bituminous lower seam, Castle Mountain mine, Matanuska field; an ash sample of the same coal contained $110 \mathrm{ppm}$ chromfum. They also reported a chromium content of 28 ppo in a whole-coal sample of a high-volatile bituminous seam from the Premier Mine, Matanuska fleld; an ash sample of this coal contalned $180 \mathrm{ppm}$ chromium. Merritt (1985b) found a mean chromium concentration of $13 \mathrm{ppm}$ in ash samples of 31 Matanuska Vailey coals.

Rao (1968) reported an average chromlum content of $7.5 \mathrm{ppm}$ in eight Kenal field whole-coal samples; ash samples of the same coals contained an average 73 ppm chromium, Rao and Wolff (1981) found a chromium content of 19 ppm in a whole-coal sample of the subbituminous C-ranked Cabin bed, Kenal fleld; an ash sample of the coal showed 170 ppr chromium. Affolter and others (1981) reported a range in chromium content from 7 to 50 ppm in 20 Healy Quadrangle whole-coal samples, and a geometric mean chromtum content of 20 ppm. In 34 Seldovia Quadrangle samples, they reported a range in chromium content of 2 to 70 ppm on a whole-coal basis and a geometric mean content $15 \mathrm{ppm}$. Merritt and others (1987) clted a mean chromium concentration of $416 \mathrm{ppm}$ in ash samples of 31 Kenai field cools.

Conwell (1977) reported a range in chromlum content from 100 to 300 ppm and a mean content of $214 \mathrm{ppm}$ in seven Beluga fleld coal-ash samples. Rao and Wolff (1981) reported a chromium content of $24 \mathrm{ppm}$ in a whole-coal sample of the subbituminous C-ranked Waterfall seam, Beluga fleld; an ash sample of the same coal contalned $230 \mathrm{ppm}$ chromium. They also reported a chromium content of 6.7 ppm (whole-coal bas19) in a Sunflower Creek ilgnite, Yeatna fleld; an ash sample of the same coal contalned 165 ppm chromlum. Based on samples of six coal beds from the Tyonek Formation, Beluga fleld, Affolter and Stricker (1984) found that the concentration of chromfum varied directly with the ash content of the coals. Rao and Smith (1987) found that the average chromium content of ash samples of five coal seams from the Chultna district, Beluga fleld, generally increased downsection. The chromium concentrations of the respective seams, as reported, were: Blue Seam (15 samples), 123 ppm; Red 3 Seam (13 samples), 159 ppm; Red 2 Seam (26 samples), 172 ppm; Red I Seam (16 samples), 167 ppm; and Purple Seam (5 samples), 198 ppm. Merrite (1987a) found a range in chromium content from <10 to $1,450 \mathrm{ppm}$ and an average content of <213 ppm for ash samples of 45 Sugltna lowland coals.

Rao and Wolff (1981) anslyzed a lignite seam from Coal Creek, Broad Pass Eleld. A raw coal sample had a chromium content of 75 ppm, and a coal-ash sample had $380 \mathrm{ppm}$.

Nenana province. Rao (1968) reported an average chromium concentration of 11.1 ppun in 25 Nenana bastn whole-coal samples; ast samples of the coals contalned an average $81 \mathrm{ppm}$ chromlum. Rao and Wolff (1981) analyzed seven samples of five Nenana basin subbituminous C-ranked coals, including the No. 2, No. 4, No. 6 (3 splits), Moose, and Cartbou seams. The whole-coal samples contained an average chromium content of $19 \mathrm{ppm}$ and the coal-ash samples contained an average chromtum content of $144 \mathrm{ppm}$. Affolter and others (1981) clted a range of 7 to $70 \mathrm{ppm}$ chromium in 20 Healy Quadrangle whole-coal samples and a geometrlc wean chromium content of 15 ppo. Affolter 
and Strlcker (1987) found an average $6.5 \mathrm{ppm}$ chromium in two whole-coal samples of Seam No. 3, Ustbell1 Mine.

Rao (1968) reported an average chromium concentration of 4.2 ppm in three Jaruis Creek field whole-coal samples; ash samples of the same coals revealed an average chromium content of 41 ppr. Belowich (1987) found an average $17 \mathrm{ppm}$ chromium in 27 Jarvis Creek field whole-coal samples. Rao and Wolff (1981) reported a chrouium content of $16 \mathrm{ppm}$ in an Ober Creek, Jarvis Creek field subbltuminous C-ranked whole-coal sample; ash of the same coal contained 140 ppm chromium.

Rao and Wolff (1981) also analyzed the maln seam, a subbltumlnous C-ranked coal, from the Little Tonzona River fleld. A whole-coal sample showed 28 ppm chromium in a whole-coal sample and an ash sample contained 200 Ppm chromium.

Alaska Penlnsula province. Conwell and Trlplehora (1978) cited an average chromium concentration of 162 ppm in eight Alaska Peninsula coal-ash samples.

Gulf of Alaska province. Rao (1969) reported an average chromium content of $1.6 \mathrm{ppm}$ in five Bering River field whole-coal samples and an average 63 ppm chromlum in ash samples of the same coals. Smith and Rao (1987) found an average chromlum concentration of $246 \mathrm{ppm}$ in 20 Bering River field coal-ash samples.

Yukon-Koyukuk province. Rao and Wolff (1981) reported the chromium content of whole-coal and ash samples of the high-volatile bituminous ranked main seaw from the Tramway Bar fleld. The former contalned $61 \mathrm{ppm}$ chromtum and the latter showed 160 ppo chromium. 


$$
\text { PROFILE } 16 \text { - COBALT }
$$

Symbol: Co

Atomic numoer: 27

Atom1c welght: 58.9332

\begin{tabular}{lcl} 
& $\frac{\text { Coal }}{70 \mathrm{ppm}}$ & \multicolumn{1}{c}{ Ash } \\
Alaska & $1-70-300 \mathrm{ppm}$ \\
U.S. & $0-90 \mathrm{ppm}$ & $0-600 \mathrm{ppm}$ \\
World & N.E. & $10-1,500 \mathrm{ppm}$
\end{tabular}

Cobalt is a metallec element found in linnaeite $\left(\mathrm{Co}_{3} \mathrm{~S}_{4}\right)$ and with arsen 1c in minerals. It is typically associated with ores of copper, 1ron, lead, nickel, and silver. The element cobalt has affinlties with both organlc and inorganic matter, but is more closely allied with inorganic fractions (Ruch and otherg, 1974\}.

Tureklan and Wedepohl (1961) reported the following average cobalt concentrations in common sedimentary rocks: shales, 19 ppw; sandstones, $0.3 \mathrm{ppm}$; and carbonates, $0.1 \mathrm{ppm}$. Orhe1m (1979) c1ted the following clarke values for cobalt: earth's crust, 25 ppm; soll, $10 \mathrm{ppm}$; plant ash, 9 ppm; and water, $0.0005 \mathrm{ppm}$.

Cobalt generally occurs in coal in appreciably greater concentrations than 1ts estimated average concentration in the earth's crugt. It is generally retalned in high-temperature ash, and over 95 percent is retalned in low-temperature ash (Ruch and others, 1974).

\section{World Coals}

Abernethy and Gibson (1963) reported an average cobalt concentration in coal of $2.9 \mathrm{ppm}$. Berkowitz (1979) reported a maximum cobalt content in coal $a \mathrm{sh}$ of $1,500 \mathrm{gm} / \mathrm{ton}$, and an average cobalt content of $300 \mathrm{gm} / \mathrm{ton}$. The U.S. National Comittee for Geochemistry (1980) clted a worldwide average cobalt content in coal of 5 ppm.

\section{United States Coals}

Sharkey and others (1975) found that cobalt occurred in 100 percent of 13 U.S. raw coals analyzed, and that it ranged in concentration from 1 to $90 \mathrm{ppm}$. Swanson and others (1976) reported an average U.S. cobalt concent of 4.6 pPm in 601 U.S. coals. The U.S. National Committee for Geochemistry (1980) reported an average cobalt concentration in U.S. coals of $7 \mathrm{pPm}$. Los Alamos Scientific Laboracory (I976) reported a range in cobalt concentration for U.S. coals of 0 to $43 \mathrm{ppm}$. They also clted a range in cobalt content in ashes of U.S. coals of 0 to $600 \mathrm{ppm}$ and average cobalt contents in asheg of U.S. coalg by rank as follows: anthracite, 81 ppm; low-volatile bituminous, 172 ppm; medium-volatile bituminous, 105 ppm; high-volatile bituminous, $64 \mathrm{ppm}$; and subbituminous and lignite, $45 \mathrm{ppm}$.

Appalachian region. Swanson and others (1976) found a geometric mean cobalt content of 5 ppm in 331 Appalachian region whole-coal samples. Los Alamos Sclentific Laboratory (1976) reported an average cobalt concentration 
of 5.1 ppm in 73 Appalachian region coals. Gluskoter and others (1977) reported a geometrlc mean cobalt content of $7.6 \mathrm{ppm}$ in 23 Appalachian region whole-coal samples.

Interior region. Swanson and others (1976) found a geometric mean cobalt content of 7 ppm in 194 Intertor region whole-coal samples. Los Alamos Sclentiflc Laboratory (1976) reported an average cobalt concentration of $3.8 \mathrm{ppm}$ in 53 Intertor region coals. Gluskoter and others (1977) reported a geometric mean cobalt content of $6.0 \mathrm{ppm}$ in 113 Illinols basin whole-coal samples.

Western region. Swanson and others (1976) reported a geometrfc mean cobalt content of $1.5 \mathrm{ppm}$ in 93 Western region coals and 5 ppm in 34 Texas coals. Los Alamos Scientific Laboratory (1976) found an average cobalt concentration of $4.6 \mathrm{ppm}$ in 48 Western and Southwestern Interior region coals and an average of $2.7 \mathrm{ppm}$ cobalt in 51 Northern Great Plains reglon coals. Gluskoter and athers (1977) cited a geometric mean cobalt concentration of $1.5 \mathrm{ppm}$ in 29 Western U.S. whole-coal samples.

\section{Alaska Coals}

Abundant data exists on cobalt concentrations in Alaska coals and coal ashes. Compared to other U.S. coals, the content of cobalt is higher in Alaskan coals.

Northern Alaska province. Rao (1968) reported an average cobalt concentration of $<3.6 \mathrm{ppm}$ in 12 Northern Alaska whole-coal samples; ash samples of the same coals revealed an average cobalt content of $<35$ pPI. Conwell and Triplehorn (1976) reported a cobalt content of 300 ppm in a Kukpuk River coal-ash sample and <10 ppm ta a Cape Thompson coal-ash sample. Rao (1980) reported a range in cobalt content from $<2$ to 51 ppm and a mean content < 8 ppm in 38 Cape Beaufort region whole-coal samples. Ash samples of the same coals showed a range in cobalt content from $<10$ to $417+$ ppm and a mean cobalt content of <41 ppm. Rao (1980) concluded that although certain of the Cape Beaufort region samples showed high concentrations of cobalt, its average concentration was low compared to other U.S. coals. Rao and Wolff (1981) analyzed subbttuminous B-ranked seams from Walnwright and Meade River, Northern Alaska. A whole-coal sample of the Walnwright seam had 3.7 ppm cobalt; an ash sample of the same coal revealed a cobalt content of 61 ppm. A whole-coal sample of the Meade River seam had 8.8 ppm cobalt; an ash sample of this coal showed a cobalt content of 200 ppm. Affolter and others (1981) reported a range in cobalt content from 1 to $70 \mathrm{ppm}$ in 54 Utukok River whole-coal samples and a geomerric mean content of 3 ppin cobalt.

Cook Inlet-Sug1tna province. Rao (1968) found an average cobalt concentration of $10.5 \mathrm{ppm}$ in 22 Matanuska Valley whole-coal samples and 100 ppm cobalt in ash samples of the same coals. Rao and Wolff (1981) reported cobalt concentrations in two high-volatile bltuminous seams from the Matanuska Valley-a seam from the Premier Mine and the lower seam from the Castle Mountain Mine. The former seam showed 40 ppm cobalt on a whole-coal basis and $260 \mathrm{ppm}$ cobalt on an ashed-basis. The latter seam revealed $7.2 \mathrm{ppm}$ cobalt on whole-coal basis and 40 ppm cobalt on an ashed-basis. Merritt 
(1985b) reported a mean cobalt content of 9 ppm in 31 Matanuska Valley coalash samples.

Rao (1968) reported an average cobalt concentration of 3.9 ppm in elght Kenai field whole-coal samples; ash samples of the same coals had 39 ppm cobalt. Rao and Wolfe (1981) found 3.1 ppa cobalt in a whole-coal sample of the subbituminous C-ranked Cabin bed, and 28 ppm cobalt in an ash sample of the same coal. Affolter and others (1981) reported a range in cobalt content from 5 to $10 \mathrm{ppm}$ and a geometric mean content of 7 ppm in 10 Kenst Quadrangle whole-coal samples. They found a range in cobalt content from 2 to 15 ppm and a geometric mean content of 5 ppm in 34 Seldovia quadrangle whole-coal samples. Merritt and otherg (1987) reported an average cobalt content of 94 ppm in 31 Kenai field coal-ash samples.

Conwell (1977) reported a range in cabalt content of 30 to $70 \mathrm{ppm}$ in seven Beluga fleld coal-ash samples and a mean of 47 ppm cobalt. Rao and Wolff (1981) found $9.0 \mathrm{ppm}$ cobalt in che subbltuminous C-ranked Waterfall bed, Beluga field on a whole-coal basis; an ash sample of the same coal had 88 ppm cobalt. An average of two whole-coal samples of the Sunflower Creek seam, a Yentna fleld lignite, showed 2.6 ppm cobalt; ash samples of the coal contained 66 ppm cobalt (Rao and Wolff, 1981). Rao and Stoith (1987) analyzed the average cobalt contents of coal-ash samples from flue seams of the Chuitna district, Beluga fleld. Results reported were: Blue Seam (15 samples), 87 ppm; Red 3 Seam ( 13 samples), 43 ppin; Red 2 Seam (26 samples), 73 ppm; Red 1 Seam (32 samples). 32 ppm; and Purple Seam (5 samples), 42 ppm. Merrltt (1987a) cited a range of <10 to 213 ppm cobalt in 45 susitna lowland coal-ash samples and an average of $<38$ ppI cobalt.

Rao and Wolff (i981) also analyzed a lignite sample from Coal Creek, Broad Pass fleld. They reported 14 ppo cobalt in a whole-coal sample and 7 I ppm cobalt in a coal-ash sample.

Nenana province. Rao (1968) found an average cobalt concentration of $<1.7$ ppm cobale 1n 25 Nenana basin whole-coal samples; ash samples of the coals contained an average of $<16 \mathrm{ppm}$ cobalt. Rao and Wolff (1981) reported an average cobalt content of 7.2 ppo in three whole-coal samples of the Nenana basin; the subbituminous C-ranked seams analyzed were the No. 4, Moose, and Carfbou seams. Coal-ash samples of the seams showed an average cobalt content of $60 \mathrm{ppm}$. Affolter and Stricker (1981) reported a range of from 1.5-10 ppm cobalt and a geometric mean of 3 ppm cobalt in 20 Healy Quadrangle whole-coal samples. Merritt (1985a) cited a general factor of enrichment for cobalt of $2.1 \mathrm{X}$ based on Nenana coal-ash samples. Affolter and Stricker (1987) reported an average cobalt content of $1.6 \mathrm{ppm}$ in two whole-coal samples of Seam No. 3, Ustbelli Mine.

Rao (1968) found an average cobalt concentration of < 1.0 ppm in three Jarvis Creek fleld whole-coal semples; ash samples of the same coals showed an average cobalt content of $<11$ ppm. Rao and Wolff (1981) reported that the cobalt content of an Ober Creek, Jarvis Creek field, subbituminous C-ranked coal was $6.8 \mathrm{ppm}$ on a whole-basis and $60 \mathrm{ppm}$ on an ash-basts. Belowich (1987) reported an average cobalt content of 12 ppo in 27 Jarvis Creek fleld whole-coal samples. 
Rao and Wolff (1981) analyzed the subbituminous C-ranked main seam from the Little Tonzans Rtver fleld. They reported a cobalt content of $10 \mathrm{ppm}$ in a whole-coal sample and 73 ppm in a coal-ash sample.

Alaska Peninsula province. Conwell and Iriplehorn (1978) reported an average cobalt concentration of 180 ppm in elght Alaska Peninsula coal-ash samples.

Gulf of Alaska province. Rao (1968) cited an average cobalt content of 1.1 ppm in five Berlug River fleld whole-coal samples. Ash samples of the same coals contalned an average cobalt content of 46 ppm. Smith and Rao (1987) reported an average cobalt concentration of $86 \mathrm{ppm}$ in 20 Bering River fleld coal-ash samples.

Yukon-Koyukuk province. Rao and Wolff (1981) reported cobalt concentrations for the high-volatile bituminous main seam of the Tramway Bar field. A whole-coal sample contalned $8.8 \mathrm{ppm}$ cobalt, and a coal-ash sample contalned 23 ppm cobalt. 


\section{PROFILE 17 - COPPER}

Symbol: $\mathrm{Cu}$

Atomic number: 29

Atomic we1ght: 63.54

$\begin{array}{lcc} & \frac{\text { Coal }}{0 \mathrm{ppm}} & 40-45 \frac{\text { Ash }}{0 \mathrm{ppm}} \\ \text { Alaska } & 2-90.5 . & 10-500 \mathrm{ppm} \\ \text { U.S. } & 1-200 \mathrm{ppm} & 10-600 \mathrm{ppm} \\ \text { World } & \text { N.E. } & \end{array}$

Copper is a metallic element of wide application. It is intimately associated with pyrice $\left(\mathrm{FeS}_{2}\right.$ ) and chalcopyrite ( $\mathrm{CuFeS}_{2}$ ), and 1 s one of the elements of environmental concern in coal. Anomalously high copper may result from core-hole samples contaminated by drilling flulds and drill plpe. Turekian and Wedepohl (1961) reported the following average copper concentrations in common sedimentary rocks: shales, $45 \mathrm{pPm}$; sandstones, $\mathrm{X}$ PPM; and carbonates, $4 \mathrm{ppm}$. Orhelm (1979) c1ted the following clarke values for copper: earth's crust, $55 \mathrm{ppm}$; so11, $20 \mathrm{ppm}$; plant ash, $180 \mathrm{ppm}$; and water, 0.003 Ppm.

Copper generally occurs in coal in appreclably greater concentration than 1 ts estimated average concentration in the earth's crust (Averlte, 1975). Copper has affinity with both organic and inorganic matter, but is more closely allied with the heavier speciflc gravity, inorganic fractions of cosl (Ruch and others, 1974; Cavallaro and others, 1978). On coal combustion, copper is generally retalned in high temperature ash and over 95 percent is retalned in low-temperature ash.

\section{World Coals}

Abernethy and Gibson (1963) reported an average copper content in coal of $8.3 \mathrm{ppm}$. The U.S. National Comittee for Geochemistry reported a worldwide average copper content in coal of $15 \mathrm{ppm}$.

\section{Untted States Coals}

Sharkey and others (1975) found that copper occurred in 100 percent of 13 U.S. raw coals analyzed, and that it ranged in concentration from 3 to 180 ppm. Others have cited a range in copper content in U.S. coals from 1.8 to $185 \mathrm{ppm}$ (Los Alamos Scientific Laboratory, 1976; Wewerka and others, 1976). Swanson and others (1976) found a geometric mean copper content in 601 U.S. coals of $14.9 \mathrm{ppm}$. The U.S. National Committee for Geochemistry (1980) reported a U.S. average copper concentration 1n coal of 19 ppm. Copper concentration in ashes of U.S. coals ranges from 10 to $100 \mathrm{ppm}$, and averages as follows in coals of varlous rank: anthracite. 405 ppm; lowvolatile bituninous, $379 \mathrm{ppm}$; medium-volatile bituminous, $313 \mathrm{ppm}$; highvolatile bituminous, $293 \mathrm{ppm}$; and subbituminous and lignite, $655 \mathrm{ppm}$ (Los Alamos Sclentific Laboracory, 1976). 
Appalachlan region. Swanson and others (1976) found a geometric mean copper content of $16 \mathrm{ppm}$ in $33 \mathrm{l}$ Appalachlan reglon whole-coal samples. Los Alamos Sclentific Laboratory (1976) reported an average copper concentration of 15 ppm in 73 Appalachian region coals. Gluskoter and others (1977) reported a geometric mean copper content of 16 ppm in 23 Appalachian region whole-coal samples.

Interior region. Swanson and ochers (1976) found a geometric mean copper content of $16.3 \mathrm{ppm}$ in 194 Intertor region whole-coal samples. Los Alamos Sctentific Laboratory (1976) reported an average copper concentration of 11 ppw in 53 Interior region coals. Gluskoter and others (1977) reported a geometric mean copper content of $13 \mathrm{ppm}$ in 113 Illinots basin whole-coal samples.

Western region. Swanson and others (1976) reported a geometric mean copper content of $7.4 \mathrm{ppm}$ in 93 Western region coals and $20 \mathrm{ppm}$ in 34 Texas coals. Los Alamos Sclentific Laboratory (1976) found an average copper concentration of 11 ppm in 48 Western and Southwestern Interior region coals and an average of 15 ppm copper in 51 Northern Great Plalns region coals. Gluskoter and others (1977) cited a geometrle mean copper concentration of $8.5 \mathrm{ppm}$ in 29 Western U.S. whole-coal samples.

\section{Alaska Coals}

Abundant data exist on copper concentrations in Alaska coals and coal ashes. Compared to other U.S. coals, the content of copper in Alaskan coals Is higher.

Northern Alaska province. Rao (1968) reported an average copper concentration of 12.2 ppm in 12 Northern Alaska whole-coal samples; ash samples of the same coals revealed an average copper content of 155 ppm. Conwe11 and Triplehorn (1976) reported a copper content of 312 ppm in a Kukpuk River coal-ash sample and 162 ppm in a Cape Thompson coal-ash sample. Rao (1980) reported a range in copper content from 2.9 to $18 \mathrm{ppm}$ and a mean content of 8.9 ppu in 38 Cape Beaufort region whole-coal samples. Ash samples of the same coals showed a range in copper content from 18 to $98 \mathrm{ppm}$ and a wean copper content of $42 \mathrm{ppm}$. Rao (1980) concluded that although certain Cape Beaufort region samples showed high concentrations of copper, its average concentration was quite low compared to other U.S. coals. Rao and Wolff (1981) analyzed subbituminous B ranked seams from Wainwright and Meade RIver, northern Alaska and a high-volatfle bltuminous seam from Sagwon Bluffs. A whole-coal sample of the Wainwrlght sean had 2.8 ppm copper; an ash sample of the same coal revealed a copper content of $46 \mathrm{ppm}$. A wholecoal sample of the Meade River seam had $4.5 \mathrm{ppm}$ copper; an ash gample of this coal showed a copper content of 103 ppm. The Sagwon Bluffs coal had 45 Ppm copper, and an ash sample of the coal had 72 ppm copper. Affolter and others (1981) reported a range in copper content from 1 to $32 \mathrm{ppm}$ in 54 Utukok River whole-coal samples and a geometric mean content of 4.8 ppo copper.

Cook Inlet-Susitna province. Rao (1968) found an average copper concentration of $22 \mathrm{ppm}$ in 22 Macanuska valley whole-coal samples and $140 \mathrm{ppm}$ copper in ash samples of the same coals. Rao and Wolff (1981) reported 
copper concentrations in two high-volatile bituminous seams from the Matanuska Valley--a seam from the Premier Mine and the lower seam from the Castle Mountain Mine. The former seam showed 13 ppm copper on a whole-coal basis and $86 \mathrm{ppm}$ copper on an ashed-bas1s. The latter seam revealed $17 \mathrm{ppm}$ copper on a whole-coal basts and 92 ppm copper on an ashed-basis. Merritt (1985b) reported a mean copper content of 30 ppia ln 31 Matanuska Valley coal-ash samples.

Rao (1968) reported an average copper concentration of $10.6 \mathrm{ppm}$ in elght Kenal field whole-coal samples; ash samples of the same coals had 104 ppm copper. Rao and Wolff (1981) found 26 ppm copper 1n a whole-coal sample of the subbituminous C-ranked Cabin bed, and 235 ppm copper in an ash sample of the same coal. Affolter and others (1981) reported a range in copper content from 7.4 to 35 ppm and a geometric mean content of $17 \mathrm{ppm}$ in 10 Kenat Quadrangle whole-coal samples. They found a range in copper content from 7.1 to $86 \mathrm{Ppm}$ and a geometric mean content of $18 \mathrm{ppm}$ in 34 Seldovia Quadrangle whole-coal samples. Merritt and others (1987) reported an average copper content of $204 \mathrm{ppm}$ in 31 Kenal fleld coal-ash samples.

Conwell (1977) reported a range in copper content of 104 to $239 \mathrm{ppm}$ in seven Beluga fleld coal-ash samples and a mean of 144 ppm copper. Rao and Wolff (1981) found $17 \mathrm{ppm}$ copper in the subbltuminous C-ranked Waterfall bed, Beluga field on a whole-coal basis; an ash sample of the same coal had 164 ppm copper. An average of two whole-coal samples of the Sunflower Creek seam, a Yentra fleld lignite, showed $9.8 \mathrm{ppm}$ copper; ash samples of the coa1 contained 240 ppm copper (Rao and Wolff, 1981). Rao and Smith (1987) analyzed the average copper contents of coal-ash samples from flve seams of the Chuitna district, Beluga fleld. Results reported were: Blue Seam (15 samples), 159 ppm; Red 3 Seam (13 samples), 370 ppm; Red 2 Seam (26 samples), 184 ppm; Red I Seam (16 samples), 142 ppm; and Purple Seam (5 samples), $150 \mathrm{ppm}$. Based on samples of $\mathrm{s} 1 \mathrm{x}$ coal beds from the Tyonek Formation, Beluga fleld, Affolter and Stricker (1984) found that the concentration of copper varled directly with the ash content of the coals. Merritt (1987a) cited a range of 25 to $390 \mathrm{ppm}$ copper and an average of 120 ppm copper in 45 Susitna lowland coal-ash semples.

Rão and Wolff (1981) also analyzed a lignite sample from Coal Creek, Broad Pass fleld. They reported 31 ppm copper In a whole-coal sample and 157 pPE copper in a coal-ash sample.

Nenana province. Rao (1968) found an average copper concentration of $10.2 \mathrm{ppm}$ in 25 Nenana basin whole-coal samples; ash samples of the coals contained an average of $89 \mathrm{ppm}$ copper. Rao and Wolff (1981) reported an average copper content of 24 ppo in seven samples of five subbituminous seams from the Nenana basin, including No. 2, No. 4, No. 6 (three splits, top, middle, and lower), Moose, and Carlbou seams. Coal-ash samples of the seams showed an average copper content of $183 \mathrm{ppm}$. Affolter and Stricker (1981) reported a range of from 8.2 to 58 ppm copper and a geometric mean of 17 ppon copper in 20 Healy Quadrangle whole-coal samples. Affolter and Stricker (1987) reported an average copper content of $7.0 \mathrm{ppm}$ in two whole-coal amples of Seam No. 3, Usibelli Mine. 
Rao (1968) found an average copper concentration of 5.2 ppm in three Jarvis Creek field whole-coal samples; ash samples of the same coals showed an average copper content of $52 \mathrm{ppm}$. Rao and Wolff (1981) reported that the copper content of an Ober Creek, Jarvis Creek fleld, subbituminous C-ranked coal was $21 \mathrm{ppm}$ on a whole-basis and $180 \mathrm{ppm}$ on an ash-basis. Belowich (1987) reported an average copper content of 51 ppm in 27 Jarvis Creek field whole-coal samples.

Rao and holff (1981) analyzed the subbituminous C-ranked main seam from the Little Tonzona River fleld. They reported a copper content of $60 \mathrm{ppm}$ in a whole-coal sample and $434 \mathrm{ppm}$ in a coal-ash sample.

Alaska Peninsula province. Conwell and Triplehorn (1978) reported an average copper concentration of 80 ppm in eight Alaska Peninsula coal-ash samples.

Gulf of Alaska province. Rao (1968) cited an average copper content of $6.0 \mathrm{ppm}$ in five Bering River field whole-coal samples. Ash samples of the same coals contained an average copper content of $260 \mathrm{ppm}$. Smith and Rao (1987) reported an average copper concentration of $166 \mathrm{ppm}$ in 20 Bering River field coal-ash samples.

Yukon-Koyukuk province. Rao and Wolff (1981) reported copper concentrations for the high-volatile bituminous main seam of the Tramway Bar field. A whole-coal sample contained 29 ppm copper, and a coal-ash sample contained 76 ppm copper. 


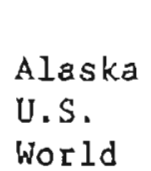

$$
\text { Coal }
$$$$
\text { N.E. }
$$

Ash

$\overline{\mathrm{N} . \mathrm{E}}$.

$<0.1-5 \mathrm{ppm}$

N.E.

N.E.

Dysprostum is a rare-earth metallic element found in assoclation with sillcate minerals. Tureklan and Wedepohl (1961) reported the following average dysprosium concentrations in common sedimentary rocks: shales, $4.6 \mathrm{ppm}$; sandstones, $7.2 \mathrm{ppm}$; and carbonates, $0.9 \mathrm{ppm}$.

Sharkey and others (1975) found that dysprosium occurred in 85 percent of 13 U.S. raw coals analyzed, and that 1t ranged in concentration from $<0.1$ to 5 ppm. The U.S. National Committee for Geochemistry (1980) reported an average dysprosium concentracion in U.S, coals of 2.2 ppm; for U.S. subbltuminous coals, they found an average $2.7 \mathrm{ppm}$ dysprosium, and for U.S. lignites, they found an average $1.4 \mathrm{ppm}$ dysprosium.

Gluskoter and others (1977) reported a geometric mean dysprosium content of 2.0 ppm in 14 Appalachian whole-coal samples, 1.0 ppm dysprosium in 56 IIlinols basin whole-coal samples, and $0.57 \mathrm{ppm}$ dysprosium in 22 Western U.S. whole-coal samples.

There is no avallable data for dysprosium concentrations in Alaska coal. 


\begin{tabular}{lll} 
& \multicolumn{1}{c}{$\operatorname{Coal}$} & Ash \\
Alaska & \multicolumn{1}{c}{ N.E. } & N.E. \\
U.S. & $<0.1-0.5 \mathrm{ppm}$ & N.E. \\
World & $0-1$ ppw & N.E.
\end{tabular}

Erbium 1s one of the rare-earth elements. Tureklan and Wedepoh1 (1961) reported the following average erblum concentrations in comon sedimentary rocks: shales, $2.5 \mathrm{ppm}$; sandstones, $4.0 \mathrm{ppm}$; and carbonates, $0.5 \mathrm{ppm}$. The average worldwide erblum content in coal is $0.6 \mathrm{ppm}$ (U.S. National Comittee for Geochemistry, 1980). Sharkey and others (1975) found that erbium occurred in 77 percent of 13 U.S. raw coals analyzed, and that it ranged in concentration from $<0.1$ to $0.4 \mathrm{ppm}$. The average U.S. erbium content is $0.34 \mathrm{ppm}$; for U.S. subbituminous coals, it is $0.46 \mathrm{ppm}$, and for U.S. IIgnites, it is $0.16 \mathrm{ppm}$ (U.S. National Comnittee for Geochemistry, 1980).

There is no avallable data on erbium concentrations in Alaska coals. 


\begin{tabular}{|c|c|c|}
\hline & Coal & Ash \\
\hline Alaska & N.E. & $\overline{N . E}$. \\
\hline U.S. & $<0.1-1 \mathrm{ppm}$ & N.E. \\
\hline World & $0-1$ ррп & N.E. \\
\hline
\end{tabular}

Europium is a rare-earth element assoclated with silicate minerals. Turekian and Wedepohl (1961) reported the following average europlum concentrations in common sedimentary rocks: shales, $1.0 \mathrm{ppm;}$ sandstones, $1.6 \mathrm{ppm}$; and carbonates, $0.2 \mathrm{ppm}$. Abernethy and Gibson (1963) found an average europium content in coal of $0.1 \mathrm{ppm}$. The U.S. Nationa 1 Comittee for Geochemistry (1980) reported an average worldwide concentration of 0.7 ppm europium in coal.

Sharkey and others (1975) found that europium occurred in 100 percent of 13 U.S. raw coals and that it ranged in concentration Erom $<0.1$ to 0.4 ppm. U.S. coals contain an average europium content of $0.45 \mathrm{ppm}$; a typical U.S. subbituminous coal contalns $0.61 \mathrm{ppm}$ europlum, and a typical U.S. 11gnite contains 0.13 ppm europium (U.S. National Committee for Geochemistry, 1980).

Gluskoter and others (1977) reported a geometric mean europium content of 0.47 ppu for 14 Appalachian region whole-coal samples, 0.25 ppm europium for 56 Illinols basin whole-coal samples, and $0.16 \mathrm{ppm}$ europlum for 22 Western U.S, whole-coal samples.

Merritt (1985b) reported a mean europlum concentration of $0.70 \mathrm{ppm}$ in ash samples of 24 Matanuska Valley coals. 
PROFILE $21-$ FLUORINE

Symbol: F Aromic number: 9

Atomic weight: 18.9984

\begin{tabular}{|c|c|c|}
\hline Alaska & $20-\frac{\operatorname{Con} 1}{350} \mathrm{ppm}$ & $\frac{\text { Ash }}{\text { N.E. }}$ \\
\hline $\begin{array}{l}\text { U.S. } \\
\text { World }\end{array}$ & $\begin{array}{c}1-1,900 \text { Ppm } \\
\text { N.E. }\end{array}$ & $\begin{array}{l}\text { N.E. } \\
\text { N.E. }\end{array}$ \\
\hline
\end{tabular}

Fluorine is a gaseous halogen element, the most electronegative and highly reactive of the elements. It is found in the minerals apattee, $\mathrm{Ca}_{5}\left(\mathrm{PO}_{4}\right)_{3}\left(\mathrm{~F}, \mathrm{CO}_{3}\right)$ and fluorapatite, $\mathrm{Ca}_{5}\left(\mathrm{PO}_{4}\right)_{3}(\mathrm{~F}, \mathrm{OH})$. Turekian and Wedepoh $(1961)$ reported the following average fluorine concentrations in common sedimentary rocks: shales, $740 \mathrm{ppm}$; sandstones, $270 \mathrm{ppm}$; and carbonates, $330 \mathrm{ppm}$. Orhe1m (1979) reported a clarke of 625 ppm fluorine in the earth's crust and a clarke of $1.3 \mathrm{ppm}$ fluorlne in water. Fluortne tends to be concentrated in the heavier specific gravity fraction of coal (Cavallaro and others, 1978). Fluorine is pregumed lost in low-temperature ash (Ruch and others, 1974).

United States Coals

Sharkey and others (1975) found that fluorine occurred in 100 percent of 13 U.S. raw coals analyzed, and that it ranged in concentration from 1 to $110 \mathrm{ppm}$. Los Alamos Sclentific Laboratory (1976) cited a range in fluorine concent in U.S. coals of from 10 to 295 ppm. Swanson and others (1976) cited an average fluorine content in 601 U.S. cosls of 61.5 ppm. Zubovic and others (1979) Indicated a range in fluorine content in U.S. coals of 0.45 to $1,900 \mathrm{ppm}$, a geometric mean of $64 \mathrm{ppm}$, and an artihmetic mean of $86 \mathrm{ppm}$. The U.S. National Committee for Geochemistry (1980) reported an average fluorine concentration in U.S. coals of $74 \mathrm{ppm}$.

Appalachtan region. Swanson and others (1976) found a geometric mean fluorine content of 60 ppro in 331 Appalachian region whole-coal samples. Gluskoter and others (1977) reported a geometric mean fluorine content of 84 ppm In 23 Appalachian region coals.

Interior region. Swanson and others (1976) found a geometric mean fluorine content of $58 \mathrm{ppm}$ in 194 Interior region whole-coal samples. Gluskoter and others (1977) reported a geometric mean fluorine content of $63 \mathrm{ppm}$ in 113 Illinols basin whole-coal samples.

Westexn region. Swanson and others (1976) found a geometric mean fluorine content of $37 \mathrm{ppm}$ in 93 Weacem U.S. coals and 91 ppm in 34 Texas coals. Gluskoter and others (1977) reported a geometrlc mean fluorine content of 57 ppm in 29 weatem U.S. whole-coal samples.

\section{Alaska Coals}

Northern Alaska province. Conwell and Triplehorn (1976) found a Eluorine concentration of $40 \mathrm{ppr}$ in a Kukpuk River whole-coal sample and 120 ppm In a Cape Thompson whole-coal sample. Affolter and others (1981) 
cited a range in fluorine content of 20 to 310 ppm in 54 Utukok Rlver Quadrangle whole-coal samples and a geometric mean fluorine content of $48 \mathrm{ppm}$.

Cook Inlet-Susitna province. Merritt (1985b) reported a mean fluorine content of 374 ppw in 24 Matanuska Valley coal-ash samples. Conwe1I (1977) clted a range of 20 to 145 ppm fluorine and a mean content of 67 ppm fluorine in seven Beluga field whole-coal samples. Based on samples of six coal beds from the Tyonek Formation, Beluga fleld, Affolter and Stricker (1984) found that the concentration of fluorine varled directly with the ash content of the coals.

Affolter and others (1981) reported a range of $<20$ to 75 ppu fluorine and a geometric mean of 31 ppm fluorine in 10 Kenai Quadrangle whole-coal samples. They also found a range of 20 to 290 ppm fluorine and a geometric mean of 55 ppm fluortne in 34 Seldovia Quadrangle whole-coal samples.

Nenana province. Affolter and others (1981) reported a range of 35 to $340 \mathrm{ppm}$ fluorine and a geometric mean of 82 ppm fluorine in 20 Healy Quadrangle whole-coal samples. Affolter and Strlcker (1987) found an average fluorine content of $88 \mathrm{ppm}$ in two whole-coal samples of Seam No. 3, Usibeli1 Mine.

Alaska Peninsula province. Conwell and Triplehorn (1978) reported an average concentration of 114 ppm fluorine in elght Alaska Peninsula whole-coal samples. 


$$
\begin{aligned}
& \text { Alaska } \\
& \text { U.S. } \\
& \text { World }
\end{aligned}
$$

\section{Coal}

N.E.

$<0.1-3 \mathrm{ppm}$

$0-5 \mathrm{ppm}$
$\underline{\mathrm{Ash}}$

$\overline{N . E}$.

N.E.

N.E.

Gadolinium is a metallic rare-earth element. Turekian and hedepohl (1961) reported the following average gadolintum concentrations in common sedimentary rocks: shales, $6.4 \mathrm{ppm}$; saudstones, $10 \mathrm{ppm}$; and carbonates, $1.3 \mathrm{ppm}$. The average worldwide gadolinium content in coal is $1.6 \mathrm{ppm}$ (U.S. Nationa1 Comittee for Geochewistry, 1980).

Sharkey and others (1975) found that gadolinfum occurred in 85 percent of 13 U.S. raw coals analyzed, and that it ranged in concentration from $<0.1$ to 3 ppr. The average U.S. gadolinlum content in coal 1s $0.17 \mathrm{ppm}$; for U.S. subbituminous coals, it averages $0.13 \mathrm{ppm}$, and for U.S. 11gnites, it averages $0.21 \mathrm{ppm}$ (U.S. National Comnittee for Geochemistry, 1980).

Merrite (1985b) reported a mean gadolinium concentration of <3 ppm in ash samples of six Matanuska Valley coals. 


Alaska
U.S.
World

$$
\begin{aligned}
& 0.3 \frac{\operatorname{Cog} 1}{-25} \text { ppm } \\
& 0-70 \text { ppm } \\
& 0-100 \text { ppal }
\end{aligned}
$$

$$
\begin{aligned}
& 10-10 \overline{\text { Ash }} \\
& 0-600 . \mathrm{ppm} \\
& 0-400 \mathrm{PPm}
\end{aligned}
$$

Gallium is a rare metaliic element that forms small highly charged ions (hfgh ion1c potentlal). It tends to be concentrated near the source areas of a coal basta (Zubovic and others, 1966a,b). Turekian and Wedepohl (1961) reported the following gallium concentrations in comon sedimentary rocks: shales, $19 \mathrm{ppm}$; sandstones, $12 \mathrm{ppm}$; and carbonates, $4 \mathrm{ppt}$. Orheim (1979) clted the following clarke values for gallium: earth's crust, 15 ppm; soll, $20 \mathrm{ppm} ;$ plant ash, $1 \mathrm{ppm} ;$ and water $0.00009 \mathrm{ppm}$.

Gallium generally occurs in coal in appreclably greater concentration that 1 ts estimated average concentration in the earth's crust (Averitt, 1975). It is an element that is assoclated with both the organic and inorganic fractions of coal, but it $1 \mathrm{~s}$ more closely allied with the organlc Eractions. On coal combustion, over 95 percent of gallium's content is retained in low-temperature ash (Ruch and others, 1974).

\section{World Coals}

Abernethy and Gibson (1963) cited an average gallium concentration in coal of $4.5 \mathrm{ppm}$. The U.S. National Comittee for Geochemistry (1980) 1ndicated a worldwide average gallium concentration in coal of $7 \mathrm{ppm}$. Berkowitz (1979) reported a maximum gallium content in coal ash of 400 gin/ton and an average gallium content of $100 \mathrm{gm} / \mathrm{ton}$.

\section{United States Coals}

Sharkey and others (1975) found that gallium occurred in 100 percent of 13 U.S. raw coals analyzed, and that it ranged in concentration from 0.3 to

$10 \mathrm{ppm}$. Los Alamos Sclentific Laboratory (1976) reported a range in gallium content of U.S. coals of 0 to $6 \mathrm{~L}$ ppm. Swanson and others (1976) found a geometric mean gallium content in $601 \mathrm{U} . \mathrm{S}$. coals of $4.7 \mathrm{ppm}$. The U.S. National Committee for Geochemistry (1980) reported a U.S. average gallium concentration in coal of $7 \mathrm{ppm}$. Gallium content in ashes of U.S. coals ranges from 0 to $540 \mathrm{ppm}$, and shows the following averages in coals of varlous rank: anthracite, $42 \mathrm{ppm}$; low volat1le bituminous, $41 \mathrm{ppm}$; highvolatile bituminous, $40 \mathrm{ppm}$; and subbltuminous and 11gnite, 23 ppm (Los Alamos Sclentific Laboratory, (976).

Appalachlan region. Swanson and others (1976) found a geometric mean gallium content of 7 pp⿴囗十 1 n 331 Appalachian reglon whole-coal samples. Los Alamos Sclentiflc Laboratory (1976) reported an average gallium concentration of 4.9 ppr in 73 Appalachian region coals. Gluskoter and others (1977) reported a geometric mean gallium content of 5.2 ppm in 23 Appalachian whole-coal samples. 
Interior region, Swanson and othera (1976) found a geometric mean gallium content of 2 ppm in 194 Intertor region whole-coal samples. Los Alamos Sclentific Laboratory (1976) reported an average gallium concentration of 4.1 ppm in 53 Interior region coals. Gluskoter and others (1977) reported a geometric mean gallium content of $3.0 \mathrm{ppm}$ in 113 Illinols basin whole-coal samples.

Western region. Swanson and others (1976) found a geometric mean gallium content of $3 \mathrm{ppm}$ in 93 Western reglon coals and $7 \mathrm{ppm}$ in 34 Texas coals. Los Alamos Sclentific Laboratory (1976) found an average gallium concentration of $2.0 \mathrm{ppm}$ in 48 Western and Southwestern Intertor region coals and an average of 5.5 ppm gallium in 51 Northern Great Plains region coals. Gluskoter and others (1977) cited a geometric mean galliun concentration of 2.1 ppm in 29 Western U.S. whole-coal samples.

\section{Alaska Coals}

Abundant data exist on gallium concentrations in Alaska coals and coal ashes. Compared to other U.S. coals, the content of gallium is higher in Alaska coala.

Northern Alaska province. Rao (1968) reported an average gallium conceatration of $3.9 \mathrm{ppm}$ in 12 Northern Alaska whole-coal samples; ash samples of the same coals revealed an average gallium content of $31 \mathrm{ppm}$. Conwell and Triplehorn (1976) reported a gallium content of 150 ppm in a Kukpuk Rlver coal-agh sample and 100 ppm In a Cape Thompson coal-ash sample. Rao (1980) reported a range in gallium content from 1.2 to $11.4 \mathrm{ppm}$ and a mean content of $6.1 \mathrm{ppm}$ in 38 Cape Beaufort reglon whole-coal samples. Ash samples of the same coals showed a range in gallium content from 16 to 53 ppm and a mean gallium content of $31 \mathrm{ppm}$. Rao (1980) concluded that the concentration of gallium in the Cape Beaufort region samples was quite low compared to other U.S. coals. Rao and Wolff (1981) analyzed subbltuminous B-ranked seams from Wainwright and Meade River, northern Alaska and a high-volatile bituminous seam from Sagwon Bluffs. A whole-coal sample of the Walowright seam had $0.84 \mathrm{ppm}$ gallium; an ash sample of the same coal revealed a gallium content of $14 \mathrm{ppm}$. A whole-coal sample of the Meade RIver seam had 4.4 ppm gallium; an ash sample of this caal showed a gallium content of 100 ppm. The Sagwon Bluffs coal had 20 ppm gallium, and an ash sample of the coal had $32 \mathrm{ppm}$ gallium. Affolter and others (1981) reported a range in gallium content from 0.3 to $20 \mathrm{ppm}$ in 54 Utukok River Quadrangle whole-coal samples and a geometrlc mean content of $3 \mathrm{ppm}$.

Cook Inlet-Sustena province. Rao (1968) found an average gallium concentration of 7.0 ppo in 22 Matanuska Valley whole-coal samples and 45 ppm gallium In ash samples of the same coals. Rao and Wolff (1981) reported gallium concentrations in two high-volatile bltumloous seams from the Matanuska Valley--a seam from the Premler Mine and the lower seam from the Castle Mountain Mine. The former seam showed 9.7 ppm gallium on a whole-coal basis and 63 ppm gallium on an ashed-bas1s. The latter seam revealed 9.4 ppw gallium on a whole-coal basis and $52 \mathrm{ppm}$ gallium on an ashed-basts. Merritt (1985b) reported a mean gallium conteot of 18 ppm in 31 Matanuska Valley coa1-ash samples. 
Rao (1968) reported an average galifum concentration of 2.1 ppm ln eight Kenal fleld whole-coal samples; ash samples of the same coals had 19 ppm gallium. Rao and Wolff (1981) found $3.0 \mathrm{ppm}$ gallium 1n a whole-coal sample of the subbltuminous C-ranked Cabin bed, and $27 \mathrm{ppm}$ gallium in an ash sample of the same coal. Affolter and others (1981) reported a range in gallium content from 1.5 to $10 \mathrm{ppm}$ and a geometric mean content of 3 ppm in 10 kenal Quadrangle whole-coal samples. They found a range in gallium content from 1 to $15 \mathrm{ppm}$ and a geometric mean concent of 3 ppm in 34 Seldovia quadrangle whole-coal samples.

Conwel1 (1977) reported a range in gallium content of 30 to $70 \mathrm{gpm}$ in seven Beluga fleld coal-ash samples and a mean of $61 \mathrm{ppm}$ gallium. Rao and Wolff (1981) found $5.3 \mathrm{ppm}$ gallium in the subbituminous C-ranked Waterfall bed. Beluga fleld on a whole-coal basis; an ash sample of the same coal had $52 \mathrm{ppm}$ gallium. An average of two whole-coal samples of the Sunflower Creek seam, a Yentna fleld 11gnite, showed 1.6 ppm gallium; ash samples of the coal contained 39 PPR gallium (Rao and Wolff, 1981). Based on samples of gix coal beds from the Tyonek Formation, Beluga fleld, Affolter and Stricker (1984) found that the concentration of gallium varied directly with the ash content of the coals.

Rao and Wolff (1981) also analyzed a lignite sample from Coal Creek, Broad Pass field. They reported 11 ppm gallium In a whole-coal sample and 57 ppm gallium in a coal-ash sample.

Nenana province. Rao (1968) found an average gallium concentration of $4.5 \mathrm{ppm}$ In 25 Nenana basin whole-coal samples; ash sample of the coals contalned an average of 36 ppm gallium. Rao and Wolff (1981) reported an average gallium content of 4.1 ppm in seven samples of five subbituminous $C$ seams from the Neaana basin, Including No. 2, No. 4, No. 6 (three splits, top, middle, and lower), Moose and Caribou seams. Coel-ash samples of the seams showed an average gallium content of $30 \mathrm{ppm}$. Affolter and Stricker (1981) reported a range of from 1.5 to 10 ppm gallium and a geometric mean of 3 ppo gailium in 20 healy Quadrangle whole-coal samples. Affolter and Stricker (1987) reported an average gallium content of $0.44 \mathrm{ppm}$ in two whole-cosl samples of Seam No. 3, Ustbell1 Mine. Merritt (1985a) reported a general factor of enrichment of $1.8 \mathrm{X}$ for gallium based on tis occurrence in Nenana basin coal-ash samples.

Rao (1968) found an average ga11fum concentration of 2.9 ppm in three Jarvis Creek fleld whole-coal samples; ash samples of the same coals showed an average gallium content of $29 \mathrm{ppm}$. Rao and Wolff (1981) reported that the galllum content of an Ober Creek, Jarvis Creek fleld, sublcuminous C-ranked coal was $2.5 \mathrm{ppm}$ on a whole-basis and $22 \mathrm{ppm}$ on an ash-basis.

Rao and Wolff (1981) also analyzed the subbltumlnous C-raaked ma1n seam Erom the Little Tonzona River fleld. They reported a gallium content of 3 ppm in a whole-coal sample and 22 ppm in a coal-ash sample.

Alaska Peninsula province. Conwell and Triplehorn (1978) reported an average gallium concentration of $28 \mathrm{ppm}$ in eight Aiaska Peninsula coal-ash samples. 
Gulf of Alaska province. Rao (1968) cited an average gallium content of 1.2 ppm in five Bering River fleld whole-coal samples. Ash samples of the same coals contained an average gallium content of 48 ppm.

Yukon-Koyukuk province. Rao and Wolff (1981) reported gallium concentrations for the high-volatile bituminous main seam of the Tramway Bar fleld. A whole-coal sample contalned $18 \mathrm{ppm}$ gallium, and a coal-ash sample contained 46 ppm gallium. 


\begin{tabular}{|c|c|c|}
\hline & Coal & Ash \\
\hline Alask & $u-1 \overline{0 p p m}$ & $0-100 \overline{\mathrm{ppm}}$ \\
\hline $\begin{array}{l}\text { U.S. } \\
\text { Wori }\end{array}$ & $\begin{array}{l}0-850 \mathrm{ppm} \\
0-1.800 \mathrm{pom}\end{array}$ & $0-1$, 500 ppm \\
\hline
\end{tabular}

Germanium is a metallold element that forms small highly charged fons (high lonic potential). It is used as a catalyst and alloying agent. Tureklan and Wedepohl (1961) reported the following average germanium concentrations in common sedimentary rocks: shales, 1.6 ppm; sandstones, $0.8 \mathrm{ppm}$; and carbonates, $0.2 \mathrm{ppm}$. Orheim (1979) cited the following clarke values for gallium: earth's crust, $1.5 \mathrm{ppm}$; so1l, 5 ppm; plant ash, 5 ppm; and water, $0.00007 \mathrm{ppm}$.

Germaniut occurs in coal in vastly greater concentration than its estimated average concentracton in the earth's crust (Avertte, 1971; 1975). It tends to be concentrated near the source areas of a coal basin (Zubovic and others, 1966a,b) and more often in the top and bottom layers of a coal bed or immedlately above a thick parting. Gemanium has been found to be more abundant in bright coal bands than in dull bands (Averite, 1961).

Much consideration and research has been directed to recovering commercial quantities of germanium from coal (Stach and others, 1982). Germantum is one of the elements showing greatest organlc affinity; it is concentrated in clean-coal fractions. Germanium is retained in hightemperature ash (Ruch and others, 1974).

\section{World Coals}

Berkowitz (1979) reported a maximum gernanfum concentration in coal ash of $11,000 \mathrm{gm} / \mathrm{ton}$ and an average content of $500 \mathrm{gro} / \mathrm{ton}$. The U.S. National Committee for Geochemistry (1980) indicated a worldwide average german1um concentration in coal of 5 ppm.

\section{U.S. $\operatorname{Cos} 1 \mathrm{~s}$}

Sharkey and others (1975) found that germanium occurred in 100 percent of 13 U.S. raw coals analyzed, and that te ranged in concentration from 0.03 to $1 \mathrm{ppm}$. The U.S. National Commttee of Geochemistry (1980) reported a U.S. average germanium content in coal of 0.71 ppm. Los Alamos Scientific Laboratory (1976) reported a range in germanium content of U.S. coals of 0 to $819 \mathrm{pPm}$, and 0 to $1,500 \mathrm{ppm}$ in ashes of U.S. coals. They found that germanium showed an average concentration of $<20$ ppw in the ashes of both U.S. anthracites and low-volatile bituminous coals.

Appalachlan region. Los Alamos Sclentific Laboratory (1976) reported an average germanium concentration of $5.8 \mathrm{ppm}$ in 73 Appalachlan region whclecoal samples. Gluskoter and others (1977) reported a geometric mean germantum concent of $0.87 \mathrm{ppm}$ in 23 Appalachian region coals. 
Interior region. Los Alamos Scientific Laboratory (1976) reported an average germanium concentration of $13 \mathrm{ppm}$ in 53 Interlor region whole-coal samples. Gluskocer and others (1977) reported a geometric mean germanium content of $4.8 \mathrm{ppm}$ in 113 Illinols basin coals.

$$
\text { Western region. Los Alamos Scientiflc Laboratory (1976) found an }
$$
average germanium concentration of $5.9 \mathrm{ppm}$ in 48 Western and Southwestern Interior region coals and an average of 1.6 ppm germanium in 51 Northern Great Plains region whole-coal samples. Gluskoter and others (1977) cited a geometric mean germantum concentration of $0.50 \mathrm{pPm}$ in 29 Western U.S. coals.

\section{Alaska Coals}

There exists very little data on germanium concentrations in Alaska coals and coal ashes.

Northern Alaska province. Conwell and Triplehorn (1976) reported a germanium content of $30 \mathrm{ppm}$ in a Kukpuk River coal-ash sample and $70 \mathrm{ppm}$ in a Cape Thompson coal-ash sample. Rao (1980) found the content of germanium in Cape Beaufort region samples to be quite low compared to other U.S. coals.

Cook Inlet-Susitns province. Merritt (1985b) reported a mean germantum content of 1.4 ppm in 29 Matanuska Valley coal-ash samples. Rao (1968) reported an average germanium concentration of 1.2 ppm in eight Kenal field whole-coal samples; ash samples of the same coals had $12.5 \mathrm{ppm}$ germanium.

Nenana province. Rao (1968) found an average germanium concentration of $<1.2$ ppm in 25 Nenana basin whole-coal samples; ash samples of the coals concalned an average of $<10.6 \mathrm{ppm}$ germanium. He also reported an average germanium concentration of 2.1 ppm in three Jarvis Creek field whole-coal samples; ash samples of the same coals showed an average germanium content of 20.1 ppm. 
PROFILE 25 - GOLD

Symbol: Au

Atomic number: 19

Aton1c weight: 196.967

$\begin{array}{lcc} & \frac{\text { Coal }}{\text { N.E. }} & \text { Ash } \\ \text { Alaska } & <0.1 \text { ppm } & \text { N.E. } \\ \text { U.S. } & \text { N.E. } & <0.1 \text { Ppm } \\ \text { World } & & \end{array}$

Gold is a highly malleable and ductile element that occurs in veins and alluvial deposits. It is a precious metal that can be recovered by panning, sluicing, or mining. Turekian and wedepoh1 (1961) reported the following average gold concentrations in common sedimentary rocks: shales, 0.00X ppm; sandstones, $0.00 \mathrm{Xpm}$; and carbonates $0.00 \mathrm{X} \mathrm{ppm}$. Orheim (1979) reported the following clarke values for gold: earth's crust, $0.004 \mathrm{ppm}$; solls, $0.002 \mathrm{ppm}$, plant ash, $0.005 \mathrm{ppm}$; and water, $0.000004 \mathrm{ppm}$. Avertet (1975) stated that gold caa be concentrated locally in some coal beds, although there is little evidence avallable to support this clalm. Gold is generally reported to be below the detection limit in coals. Berkowitz (1979) clted a maximum concentration of gold in coal ash of $0.1 \mathrm{gm} / \mathrm{ton}$. Sharkey and others (1975) found that the concentration of gold in 13 U.S. raw coal samples was $<0.1 \mathrm{ppm}$.

Gold was reported to be below the detection limit in two coal-ash samples from northern Alaska---Kukpuk R1ver and Cape Thompson---analyzed by Conwell and Triplehorn (1976). 


$$
\text { PROFILE } 26 \text { - HAFNIUM }
$$

Symbol: HE

Atomlc weight: 178.49

$\begin{array}{lcr} & \frac{\text { Coal }}{N . E .} & \frac{\text { Ash }}{\text { Alaska }} \\ \text { U.S. } & 0.1-5 \text { ppm } & \text { N.E. } \\ \text { World } & \text { N.E. } & \text { N.E. }\end{array}$

Hafnium is a metallic element generally assoclated with silfcate minerals, and that can be separated from ores of zirconfum. Turektan and Wedepoh1 (196l) reported the followlng average hafnlum concentrations in common sedimentary rocks: shales, 2.8 ppm; sandstones, 3.9 ppm; and carbonates, $0.3 \mathrm{ppm}$. Abernechy and Gibson (1963) reported an average hafnium concentration in coal of $0.4 \mathrm{ppm}$.

Sharkey and others (1975) found that hafnium occurred in 46 percent of 13 U.S. raw coals analyzed, and that it ranged in concentration from $<0.3$ to $4 \mathrm{ppm}$. The U.S. average hafnium content in coal ts $0.60 \mathrm{ppm}$ (U.S. National Commltee for Geochemistry, 1980). Gluskoter and others (1977) reported a geometric mean hafnium concent of 1.1 ppm in 14 Appalachian region whole-cosi samples, 0.49 ppm hafnium in 56 Illinols basin whole-coal samples, and $0.70 \mathrm{ppm}$ hafnlum in 22 Western U.S. whole-coal samples. Wewerka and others (1979) clted a range in hafnium concencration in ashes of Illinois basin coals of 1.3 to $2.9 \mathrm{ppm}$ and a mean hafnium concentration of $1.8 \mathrm{ppm}$.

Merr1tt (1985b) reported a mean hafnium content of <3 ppm in ash samples of three Matanusta Valley coals. 
PROFILE 27 - HOLMIUM

Symbol: Ho

Acomic number: 67

Atomic weight: 164.930

\begin{tabular}{ll} 
& \multicolumn{1}{c}{$\frac{C o a l}{N . E .}$} \\
Alaska & $<0.1-0.5 \mathrm{ppm}$ \\
U.S. & $0-1 \mathrm{ppm}$
\end{tabular}

Ash

$\overline{N . E}$.

N.E.

N.E.

Holmlum is a stable rare-earth element. Turekian and Wedepohl (1961) reported the following average holmium concentrations in common sedimentary rocks: shales, $1.2 \mathrm{ppm}$; sandstones, $2.0 \mathrm{ppm}$; and carbonates, $0.3 \mathrm{ppm}$.

Sharkey and others (1975) found that holmlum occurred in 77 percent of 13 U.S. raw coals analyzed, and that it ranged in concentration from $<0.1$ to $0.4 \mathrm{ppm}$. The average worldwide holmium content in coal $1 \mathrm{~s} 0.3 \mathrm{ppm}$. The average U.S. holmium content in coal is $0.11 \mathrm{ppm}$; for U.S. subbituminous coals, it $1 \mathrm{~s} 0.13 \mathrm{ppm}$, and for U.S. 11gnites it is $0.06 \mathrm{ppm}$ (U.S. National Comititee for Geochemistry, 1980).

There is no avallable data on holmiun concentrations in Alaska coals. 


\section{PROFILE 28 - KYOROGEN}

Symbol: $\quad \mathrm{H}$

Atomic number: 1

Atomic weight: 1.00797

$\begin{array}{lll} & \text { Coa1 } & \underline{\text { Ash }} \\ \text { Alaska } & 40,00 \overline{0-70}, 000 \mathrm{ppm} & - \\ \text { U.S. } & 38,000-60,000 \mathrm{ppm} & - \\ \text { World } & 15,000-75,000 \mathrm{ppm} & -\end{array}$

Hydrogen 1s a gaseous element, the lightest of all gases, and the most abundant element in the universe. It belongs to the organic mineral group of elements (Wewerka and others, 1978). Among hydrogen's many uses are in wethanol production, petroleum refining, and hydrogenation of organic materials.

Gluskoter and others (1977) reported a geometrlc mean hydrogen content of 4.9 percent for 22 Appalachian reglon whole-coal samples, 5.0 percent for 110 Illinols basin whole-cosl samples, and 4.6 percent for 29 Western U.S. whole-coal samples.

Alaskan coals are simllar in hydrogen composition to other U.S. coals when considered by rank. For example, a high-volatile A bituminous coal from the Matanuska Valley contalns about 4.7 percent hydrogen, whereas Nenana and Beluga subbituminous coals contain about 6.2 percent hydrogen (equilibrium bed moisture basis). 
PROFILE $29-$ INDIUM

Symbo1: In

Atomic number: 49

Atomic weight: 114.82

$\begin{array}{lcc} & \text { Coal } & \text { Ash } \\ \text { Alaska } & \text { N.E. } & \text { N.E. } \\ \text { U.S. } & 0.01-0.7 \text { Ppm } & \text { N.E. } \\ \text { World } & \text { N.E. } & \text { N.E. }\end{array}$

Indium is a metallic element found principally in ores of tin and zinc. Tureklan and Wedepohl (1961) reported the following average lndium concentrations in common sedimentary rocks: shales, $0.1 \mathrm{ppm}$; sandstones, $0.0 \mathrm{Xpp}$; and carbonates, $0.0 \mathrm{X} \mathrm{pm}$. Orheim (1979) reported a clarke value for indium in the earth's crust of $0.1 \mathrm{ppm}$.

Indium ts one of the elements of chief euvironmental concern in coal. Berkowtiz (1979) clted a maximum concentration of 1nd1um in coal ash of $2 \mathrm{gm} / \mathrm{con}$.

Gluskoter and others (1977) reported a geometrlc mean indium content of 0.22 pom for 14 Appalachian region whole-coal samples, 0.13 ppm for 56 Illinols basin whole-coal samples, and 0.07 ppm for 22 Western U.S. wholecoa1 samples.

There is no avallable data on Indium concentrations in Alaska coals. 
PROFILE 30 - IODINE

Symbol: I

Atomic number: 53

Atomic weight: 126.9044
Alaska
Coal
U.S.
N.E.
Ash
$<0.1-15 \mathrm{ppm}$
$\overline{N .2 .}$
N.E.
N.E.
N. $E$.

Iodine is a poisonous halogen element having radioactive isotopes, especially I 131. Turektan and Wedepoh1 (1961) reported the following average lodine concentrations in common sedimentary rocks: shales, 2.2 ppm; sandstones, 1.7 pPm; and carbonates, 1.2 ppm. Orhe1m (1979) reported the following clarke values for lodine: earth's crust, $0.5 \mathrm{ppm}$, and water, $0.06 \mathrm{pPm}$.

Sharkey and others (1979) found that lodine occurred in 95 percent of 13 U.S. raw coals analyzed, and that it ranged in concentration from $<0.1$ to $4 \mathrm{ppm}$. The U.S. average lodine content in coal is $1.10 \mathrm{ppm}$ (U.S. National Committee for Geochemistry, 1980). Gluskoter and others (1977) reported a geometric mean lodine content of 1.4 ppm in 14 Appalachlan region whole-coal samples, $1.2 \mathrm{ppm}$ iodine in 56 Illinois basin whole-coal samples, and $0.46 \mathrm{ppm}$ lodine in 22 Western U.S. whole-coal samples.

Merritt (1985b) reported a mean lodine content of 3.7 ppm in ash samples of 30 Matanuska Valley coals. 


\section{PROFILE 31 - IRIDIUM}

Symbol: Ir

Atomic number: 77

Atomic welght: 192.2

Alaska
U.S.
World

Coa 1

N.E.

Ash

$<0.2 \mathrm{ppm}$

N.E.

$N, E$.

N.E.

N.E.

Iridium is a metallic element found in platinum ores. Sharkey and others (1975) found that Iridium content was <0.2 ppm in 13 U.S. raw coals analyzed. Somerville and Elder (1977) reported that irfdium content was below the 0.1 ppm detection limit in North Dakota Iignite samples. There is no avallable data on iridium concentrations in Alaska coals. 
PROFILE $32-\underline{\text { IRON }}$

Symbol: $\mathrm{Fe} \quad$ Atomic number: 26

Atomlc welght: 55.847

$\begin{array}{lcc} & \text { Coa } 1 & \frac{\text { Ash }}{N . E} \\ \text { Alaska } & 1,000-24,000 \mathrm{ppm} & 20,000-250,000 \mathrm{ppm} \\ \text { U.S. } & 1,000-50,000 \mathrm{pPm} & \text { N.E. } \\ \text { World } & \text { N.E. } & \end{array}$

Iron is a metallic element used as an alloy in a wide variety of important structural materials. It is contalned in sulfide and carbonate minerals, lacluding pyrite $\left(\mathrm{FeS}_{2}\right)$, marcasite $\left(\mathrm{FeS}_{2}\right)$, hematite $\left(\mathrm{Fe}_{2} \mathrm{O}_{3}\right)$, siderite $\left(\mathrm{FeCO}_{3}\right)$, limonite $\left[\mathrm{FeO}(\mathrm{OH}) \cdot \mathrm{nH}_{2} \mathrm{O}\right]$, magnetite $\left(\mathrm{Fe}_{3} \mathrm{O}_{4}\right)$, and tacontte. The latter is a sedimentary rock and low-grade lron ore consisting of magnetite, hematite, and quartz. Iron has an important effect on the use of coal in combustion and cokemaking.

Tureklan and Wedepohl (1961) reported the following average iron concentrations in common sedimentary rocks: shales, 47,200 ppm; sandstones, 9,800 ppm; and carbonates, $3,800 \mathrm{ppm}$. Orheim (1979) cleed the following clarke values for 1ron: earth's crust, 64,500 ppm; so1l, 30,000 ppm; plant ash, 6,700 ppm; and water $0.01 \mathrm{ppo}$.

\section{Wor ld Coals}

Iron is an important inorganic element of coal. Abernethy and Gibson (1963) reported an suerage tron concentration in coal of 10,850 ppm. The U.S. National Committee for Geochemistry reported a mean worldwide iron content in coal of 1.0 percent.

\section{United States Coals}

Sharkey and others (1975) found that tron occurred in 100 percent of 13 U.S. raw coals analyzed, and that it ranged in concentration from 1,400 to $12,000 \mathrm{ppm}$. Others have reported that iron content in U.S. coals ranges from 0.32 to 4.32 percent (Los Alamos Sclentific Laboratory, 1976; Wewerka and others, 1976). Swanson and others (1976) reported an average iron content of 1.3 percent in 601 U.S. coals, and the U.S. National Comittee for Geochemistry (1980) cited an average iron concentration in U.S. coals of 1.6 percent.

Iron oxide 15 one of the major constituents of coal ash. In ashes of U.S. coals, Iron ranges in content from 2.09 to 24.4 percent (Los Alamos Sclentific Laboratory, 1976).

Appalachian region. Swanson and others (1976) found a geometric mean of 1.0 percent iron in 331 Appalachlan region whole-coal samples. Gluskoter and others (1977) reported a geometric mean tron content of 1.3 percent in 23 Appalachian region coals. 
Interfor region. Swanson and others (1976) found a geometric mean iron content of 2.3 percent in 194 Interlor region whole-coal samples. GIuskoter and others (1977) reported a geometric mean-iron concent of 1.9 percent in 113 Illinols basin coals.

Western region. Swanson and others (1976) found a geometric mean iron content of 0.45 percent in 93 hestern region whole-coal samples, and 1.6 percent $1 n 34$ Texas coals. Gluskoter and others (1977) reported a geometrlc mean iron content of 0.49 percent in 29 Western U.S. coals.

\section{Alaska Coals}

Affolter and others (1981) reported geometric mean lron concentrations of 0.32 percent, 0.41 percent, 0.54 percent, and 0.32 percent in whole-coal samples of the Healy (20), Kenai (10), Seldovla (34), and Utukok RIver (54) Quadrangles, respectively. Compared to 410 Powder River region and 295 Rocky Mountain province coal samples, the contents of tron in these Alaskan coals is not significautly different. 
PROFILE 33 - LANTHANUM

Symbol: La

Atomic number: 57

Atomic weight: 138.91

$\begin{array}{ll} & \text { Coal } \\ \text { Alaska } & 5-30 \mathrm{ppm} \\ \text { U.S. } & 0-100 \mathrm{ppm} \\ \text { World } & 0-100 \mathrm{ppm}\end{array}$

Laathanum is a metalifc rare-earth element that is obtained chfefly from monazite $\left[(\mathrm{Ce}, \mathrm{La}, \mathrm{Y}, \mathrm{Th}) \mathrm{PO}_{4}\right]$. It is comonly found in assoclation with sllicate minerals. Turekian and Wedepohl (1961) reported the following average lanthaaum concentrations in common sedimentary rocks: shales, 92 ppm; sandstones, $30 \mathrm{ppr}$; and carbonates, X ppm.

\section{World Coals}

Lanthanum generally occurs in coal in appreciably greater concentration than its estimated average concentration in the earth's crust (Averitt, 1975). Abernethy and Glbson (1963) reported a general average lanthanum concentration in coal of $3.8 \mathrm{ppm}$. The U.S. National Committee for Geochemistry (1980) cited a worldwide average lanthanum concentration in coal of $10 \mathrm{pPm}$.

\section{United States Coa1}

Sharkey and others (1975) found that lanthanum occurred in 100 percent of 13 U.S. raw coals analyzed, and that it ranged in concentration from 0.3 to $29 \mathrm{ppm}$. Others have cited a range in lanthanum content in U.S. coals from 0 to 98 ppm (Los Alamos Scientific Laboratory, 1976), and an average concentration of 6.1 ppm (U.S. National Committee for Geochemlstry, 1980). In sshes of U.S. coals, lanthanum exhibits a range from 0 to 820 ppm and average concentrations, by rank, as follows: anthrac1tes, $142 \mathrm{ppm}$; lowvolacile bituminous, 110 ppr; medium-volatile bituminous, 83 ppm; highvolatile bituminous, $111 \mathrm{ppm}$; and subbicuminous and lignite, 62 ppm (Los Alamos Sciencific Laboratory, 1976).

Appalachian region. Los Alamos Sclentific Laboratory (1976) reported an average lanthanum concentracion of 9.4 ppm in 73 Appalachian region whole-coal samples. Gluskoter and others (1977) reported a geometric mean lanthanum content of 14 ppol in 14 Appalachian reglon coals.

Intertor region. Los Alamos Scientiflc Laboratory (1976) reported an average lanthanum concentracion of 5.1 ppm in 53 Intertor region whole-coal samples. Gluskoter and others (1977) reported a geometric mean lanthanum concentration of $6.4 \mathrm{ppm}$ in 56 Illinois basin coals.

Western region. Los Alamos Sclentific Laboratory (1976) reported an average lanthanum concentration of $6.5 \mathrm{ppm}$ in 48 Western and Southwestern Incerior region coals, and an average of 9.5 ppm lanthanum in 51 Northern Great Plains region coals. Gluskoter and others (1977) reported a geometric mean lanthanum concentration of $4.5 \mathrm{ppm}$ in 22 Western U.S. coals. 
Northern Alaska province. Conwell and Triplehora (1976) found a lanchanum content of $500 \mathrm{ppm}$ in a Kukpuk River coal-ash sample, and $100 \mathrm{ppm}$ in a Cape Thompson coal-ash sample.

Cook Inlet-Sustena province. Merrite (1985b) reported a mean lanthanum content of 26 ppm in 31 Matanuska Valley coal-ash samples. Affolter and others (1981) reported a range in lanthanum content of 5 ro 30 ppm In 34 Seldovia Quadrangle whole-coal samples, and a geometric mean lanthanum content of 3 ppm. Conwell (1977) clted a mean lanthanum concentration <100 ppm In seven Beluga fleld coal-ash samples. Based on samples of six coal beds from the Tyonek Formation, Beluga fleld, Affolter and Stricker (1984) found that the concentration of lanthanum varled directly with the ash content of the coals.

Nenana province. Affolter and others (1981) clted a range in lanthanum content from 10 to $20 \mathrm{ppm}$ and a geometric mean of 7 ppm lanthanum in 20 Healy quadrangle whole-coal samples. Affolter and Strlcker (1987) found an average of $1.8 \mathrm{ppm}$ lanthanum in two whole-coal samples of Seam No. 3, Usibeli1 Mine.

Alaska Peninsula province. Conwell and Triplehorn (1978) reported an average lanthanum concentration of $<100$ ppm in elght Alaska Pentnsula coal-ash samples. 
PROFILE $34-\underline{\text { LEAD }}$

Symbo1: $\mathrm{Pb}$

Atomic number: 82

Atomic welght: 207.19

$\begin{array}{ll} & \frac{\operatorname{Coa} 1}{35 \mathrm{ppm}} \\ \text { Alaska } & 1-3 . \\ \text { World } & 1-220 \mathrm{ppm} \\ \text { Word } & 0-300 \mathrm{ppm}\end{array}$

$$
\begin{aligned}
& \text { Ash } \\
& 20-3 \frac{\overline{5}}{50} \mathrm{ppm} \\
& 10-1,500 \mathrm{ppm} \\
& 10-1,000 \mathrm{ppm}
\end{aligned}
$$

Lead is a dense metallic element that is associated with the mineral galena (PbS). Tureklan and Wedepoh1 (1961) reported the following average lead concentrations in common sedimentary rocks: shales, 20 ppm; sandstones, 7 ppm; and carbonates, $9 \mathrm{ppm}$. Orhelm (1979) cited the following clarke values for lead: earth's crust, 12.5 ppor soil, $10 \mathrm{ppm}$; plant ash, 70 ppm; and water, $0.00003 \mathrm{ppm}$. Lead occurs in coal in appreclably greater concentration than its estimated average concentration in the earth's crust (Averitt, 1961; 1975). Lead shows a 11mited enrichment factor of $1.28 \mathrm{X}$ in coal (U.S. National Commttee for Geochemistry, 1980).

Lead is generally inorganically combined in coal; it is one of the elements showing least organic affinity (Ruch and others, 1974). It tends to be concentrated in the heavier specific gravity or mineral matter fraction of coal (Cavallaro and others, 1978).

Lead is one of the elements of chief environmental concern in coal; it is generally toxic to plant and animal Iffe at relatively low concentrations (Ruch and others, 1974). It is commonly enriched on the surfaces of fly-ash particles released from coal-combustion sources (Mraw and others, 1983). Lead is generaily retained in high-cempersture ash, and over 95 percent is retained in low-temperature ash (Ruch and others, 1974). Anomalously high lead in core-hole coal samples can result from contaminated drilling fluids and drill plpe.

\section{World Coals}

Abernethy and Gibson (1963) reported an average lead content in coal of $4.9 \mathrm{ppm}$. The U.S. National Committee for Geochemistry (1980) cited a worldwide average lead concentration in cosl of $25 \mathrm{ppm}$. Berkowitz (1979) cited a maximum concentration of lead in cosl ash of $1,000 \mathrm{gm} /$ ton and an average concentration of $100 \mathrm{gm} / \mathrm{ton}$.

\section{Unted States Coals}

Sharkey and others (1975) found that lead occurred in 100 percent of 13 U.S. coals analyzed, and that it ranged in concentration from 1 to $36 \mathrm{ppm}$. Others have reported a range in lead concentration in U.S. coals from 4 to 218 ppm (Los Alamos Sclentiflc Laboratory, 1976; Wewerka and others, 1976). Swanson and others (1976) reported an average lead content of 9.2 ppm $1 \mathrm{n} 601$ U.S. coals, and the U.S. National Comittee for Geochemistry (1980) reported an average lead content of $16 \mathrm{ppm}$ in U.S. coals. In ashes of U.S. coals, lead ranges in content from 10 to $1,420 \mathrm{ppm}$, and occurs in the following 
average concentrations in the ashes of coals of various rank: anthracites, 81 ppm; low-volatile bltuminous, 89 ppm; medium-volatile bituminous, 96 ppm; high-volatile bituminous, $183 \mathrm{ppm}$; and subbituminous and 1ignite, 60 ppm (Los Alamos Scientific Laboratory, 1976).

Appalachian regton. Swanson and others (1976) reported a geometric mean content of 10.9 ppm lead in 331 Appalachian region whole-coal samples. Gluskoter and others (1977) reported a geometric mean content of 4.7 ppm lead In 23 Appalachian region coals.

Interfor region. Swanson and otherg (1976) reported a geometric mean lead content of $19 \mathrm{ppm}$ in 194 Interior region whole-coal samples. Gluskocer and others (1977) reported a geometric mean content of 15 ppm lead in 113 Illinols basin whole-coal samples.

Wegtern reglon. Swanson and others (1976) reported a geometric mean lead content of 4.3 ppw in 93 Western region whole-coal samples and a geometrlc mean of 2.8 ppm lead in 34 Texas coals. Gluskoter and others (1977) reported a geometric mean content of 2.6 ppm lead in 29 Western U.S. cosls.

\section{Alaska Coals}

There exists an abundant amount of data relating to lead concentrations in Alaska coals and coel ashes.

Northern Alaska province. Rao (1968) reported an average concentration of 13.9 ppm lead in 12 Northern Alaska whole-coal samples; ash samples of the same coals contalued an average of 153 ppm lead. Conwell and Triplehorn (1976) Found an average content of 430 ppm lead in a Kukpuk River coal-ash semple and 330 ppm lead in a Cape Thompson coal-ash sample. Rao (1980) analyzed and reported on lead concentrations in some 38 Cape Beaufort region whole-coal and coal-ash samples. A1though certa1n of the Cape Beaufort region coals showed high concentrations of lead, the average concentration was quite low compared to other U.S. coals. In raw coals, lead ranged from $<2$ to $41 \mathrm{ppm}$ and had a mean content <12 ppm; in coal-ash samples, lead ranged from $<20$ to $253 \mathrm{ppm}$ and had a mean content <56 ppm (Rao, 1980). Rao and Wolff (1981) found $7.9 \mathrm{ppm}$ lead in a whole-coal sample of a subbituminous $B$ seam from Meade River, northern Alaska; ash of the same coal contained $180 \mathrm{ppm}$ lead. They reported a whole-coal lead content of 13 ppm in a highvolatile bltuminous seam from Sagwon Bluffs, northern Alaska; ash of the same coal contalned 21 ppm lead. Affolter and others (1981) reported a range in lead concentration of 1 to 21 ppm for 54 Utukok River Quadrangle whole-coal samples and a geometric mean content of $1.7 \mathrm{ppm}$.

Cook Inlet-Susitna province. Rao (1968) reported an average lead content of 13.6 ppm in 22 Matanuaka Valley whole-coal sampleg and an average lead content of $102 \mathrm{ppm}$ in ash samples of the same coals. Rao and Wolff (1981) found a lead content of $4.5 \mathrm{ppm}$ in a whole-coal sample of the hlghvolatlle bituminous lower seam, Castle Mountain mine, Matanuska fleld; an ash sample of the same coal contained $25 \mathrm{ppm}$ lead. They also reported a lead content of $4.3 \mathrm{ppm}$ in a whole-coal sample of a high-volat1le bituminous seam 
from the Premier mine, Matanuska field; an ash sample of this coal contained 28 ppm lead. Merritt (1985b) found a mean lead concentration of $10 \mathrm{ppm}$ in 31 Matanuska Valley coal-ash samples.

Rao (1968) reported an average lead content of 8.7 ppm in eight Kenal Fleld whole-coal samples; ash samples of the same coals contalned an average 89 ppw lead. Rao and Wolff (1981) found a lead content of 4.7 ppri in a whole-coal sample of the subbltuminous C-ranked Cabin bed, Kenai field; an ash sample of the coal showed 42 ppr lead. Affolter and others (1981) reported a range in lead content from $<1.5$ to 11 ppm in 34 Seldovia Quadrangle whole-coal samples, and a geometric mean lead content of 2.0 ppr. Merritt and others (1987) cited a mean lead concentration of <61 ppm in ash samples of 31 Kenai fleld coals.

Conwell (1977) reported a range in lead content from 25 to $60 \mathrm{ppm}$ and a mean content of 38 ppe in seven Beluga fleld coal-ash samples. Rao and Wolff (1981) reported a lead content of $11 \mathrm{PpD}$ in a whole-coal sample of the subbltuminous C-ranked Waterfall seam, Beluga fleld; an ash sample of the same coal contalned $110 \mathrm{ppm}$ lead. They also reported a lead content of 2.4 ppm (whole-coal basis) in a Sunflower Creek lignite from the Yentma Fleld; an ash sample of the same coal contained 62 ppm lead. Merritt (1987a) found a range in lead content from 8 co 69 ppm and an average content of 22 ppm for ash samples of 65 Susitna lowland coals.

Rao and Wolff (198l) analyzed a lignite seat Erow Coal Creek, Broad Pass fleld. A raw coal sample had a lead content of $19 \mathrm{ppm}$, and a coal-ash sample had 99 ppm.

Nenana province. Rao (1968) reported an average lead concentration of 12. I ppu in 25 Nenana basin whole-coal samples; ash samples of the coals contalned an average $117 \mathrm{ppm}$ lead. Rao and Wolff (1981) analyzed flve samples of four Nenana basin subbituminous C-ranked coals, Including the No. 4, No. 6 (two splits, top, and lower), Moose, and Caribou seams. The whole-coal samples contayned an average lead content of 14 ppm and the coal-ash samples contalned an average lead content of 123 ppm. Affolter and others (1981) cited a range of <2 to 15 ppm lead in 20 Healy Quadrangle whole-coal samples and a geometric mean lead content of $4.5 \mathrm{ppm}$. Affolter and Stricker (1987) Eound an average 1.8 ppr lead in two whole-coal samples of Seam No. 3, Usibelli Mine. Merritt (1985a) reported a general factor of enrichment for lead of $6.2 \mathrm{X}$ based on Nenana basin coal-ash samples.

Rao (1968) reported an average lead concentration of $5.4 \mathrm{ppm}$ in three Jaruis Creek fleld whole-coal samples; ash samples of the same coals revealed an average lead content of $52 \mathrm{ppm}$.

Rao and Wolff (1981) also analyzed the subbltuminous C-ranked main seam of the Little Tonzona River fleld, western Nenana province. A whole-coal sample comtalned 7.8 ppm lead, and a coal-ash sample contained 57 ppm lead.

Alaska Peninsula province. Conwell and Triplehorn (1978) cited an average lead concentration of $<32 \mathrm{ppm}$ in eight Alaska Peninsula coal-ash samples. 
Gulf of Alaska province. Rao (1968) reported an average lead content of $6.6 \mathrm{ppm}$ in five Bering River fleld whole-coal samples and an average 268 ppm lead in ash samples of the same coals.

Yukon-Koyukuk province. Rao and Wolff (1981) clted a whole-coal lead concentration of 23 ppm and a coal-ash lead concentration of $59 \mathrm{ppm}$ in a high-volatile bltuminous seam of the Tramway Bar field. 


$\begin{array}{llc} & \frac{\text { Coal }}{-90} \mathrm{Ppm} & \text { Ash } \\ \text { Alaska } & 0.50-800 \mathrm{ppm} \\ \text { U.S. } & 0.1-350 \mathrm{PPm} & <20-3,200 \mathrm{PPm} \\ \text { World } & \text { N.E. } & \text { N.E. }\end{array}$

Lithlum is a highly-reactive metallic element that is generally found in association with silfcate minerals. Tureklan and WedepohI (1961) reported the following average lithium concentrations in common sedimentary rocks: shales, 66 ppm; sandstones, 15 ppm; and carbonates, 5 ppm. Orhe1m (1979) clied the following clarke values for 11thlum: earth's crust, 20 ppm; soll, $30 \mathrm{ppm}$; plant ash, $2 \mathrm{ppm}$; and water $0.003 \mathrm{ppm}$. Lith1um generally occurs in coal in appreclably greater concentration than its estimated average concentration in the earth's cruse (Averitt, 1975).

World Coals

The U.S. National Commitcee for Geochemistry (1980) cited a worldwide average lithium content in coal of $65 \mathrm{ppm}$. Barkowltz (1979) reported a maximum lithlum concentration in coal ash of $500 \mathrm{gm} / \mathrm{ton}$.

\section{United States Coals}

Sharkey and others (1975) found that lithlum occurred in 100 percent of 13 U.S. raw coals analyzed, and that it ranged in concentration from 4 to $163 \mathrm{ppm}$. Swanson and others (1976) reported an average Ilthium cantent of $11 \mathrm{ppm}$ in $601 \mathrm{U} . \mathrm{S}$. coals, and the following average concentrations by rank: anthracite, $33 \mathrm{ppm;} \mathrm{bituminous,} 23 \mathrm{ppm;}$ subbituminous, $7 \mathrm{ppm}$; and lignite, 19 ppm. Medlin and others (1979) found a range in lithium concentration in U.S. coals of 0.17 to $350 \mathrm{ppm}$, a geometric mean of $8.3 \mathrm{ppm}$ Iithium, and an arithmetic mean of $15 \mathrm{ppm}$ lithium. The U.S. Natlonal Committee for Geochemistry (1980) cited an average lithlum concentration in U.S. coals of 20 ppm. Los Alamos Scientific Laboratory (1976) reported a range in lithium content of $<20$ to $3,100 \mathrm{ppm}$ in ashes of U.S. coals.

Swanson and others (1976) also reported the following geometric mean lithlum concentrations in whole-coal samples of different regions of the United States: Appalachlan region (331 samples), $18.8 \mathrm{ppm}$; Interior region (194 samples), 7 ppm; Western region (93 samples), 4.3 ppm; and Texas ( 34 samples), 14 ppm.

Alaska Coals

Compared to other U.S. coals, the content of lithium in Alaskan coals is stollar. 
Northern Alaska province. Conwell and Triplehorn (1976) reported a 11thium content of $683 \mathrm{pPm}$ in a Kukpuk River coal-ash sample and $744 \mathrm{ppm}$ in a Cape Thompson coal-ash sample. Affolter and others (1981) found a range in lithium content in 54 Utukok River quadrangle whole-coal samples of 0.5 to 84 ppm and a geometric mean 11 thium content of 9.5 ppm.

Cook Inlet-Susitna province. Merritt (1985b) cited a mean lithium concentration of $168 \mathrm{ppm}$ in 30 Matanuska Valley coal-ash samples. Affolter and others (1981) reported a range in l1thium content of $<1$ to $13 \mathrm{ppm}$ and a geometric mean content of $4 \mathrm{ppm}$ in 10 Renal Quadrangle whole-coal samples. They reported a range in lithlum content of 0.6 to 26 ppm and a geometric mean content of 3.6 ppm in 34 Seldovia Quadrangle whole-coal samples. Conwell (1977) found a range of 27 to $89 \mathrm{ppm}$ lithium and a mean of $60 \mathrm{ppm}$ lithium in seven Beluga field coal-ash samples. Based on samples of six coal beds from the Tyonek Formation, Beluga fleld, Affolter and Stricker (1984) found that the concentration of lithlum varled directly with the ash content of the coals.

Nenana province. Affolter and others (1981) reported a range in Iithium content of 1.3 to $32 \mathrm{ppm}$ and a geometric wean of $3.7 \mathrm{ppm} 11$ thium in $20 \mathrm{Healy}$ Quadrangle whole-coal samples. Affolter and Strdcker (1987) reported an average of $0.6 \mathrm{ppm} 1 \mathrm{lth} 1 \mathrm{~m}$ in two whole-coal samples of Seam No. 3, Usibell1 Mine.

Alaska Peninsula province. Conwell and Tr1plehorn (1978) reported an average lithium content of 127 ppm in elght Alaska Peninsula coal-ash samples. 


$\begin{array}{lcc} & \frac{\text { Coal }}{\text { N.E. }} & \frac{\text { Ash }}{\text { N.E. }} \\ \text { U.S. } & 0.01-0.5 \text { ppm } & \text { N.E. } \\ \text { World } & \text { N.E. } & \text { N.E. }\end{array}$

Lutetium is a rare-earth element associated with silicate minerals. Turekian and Wedepohl (1961) reported the following average lutetium concentrations 1 n common sedimentary rocks: shales, 0.7 ppm; sandstones, $1.2 \mathrm{ppm}$; and carbonates, $0.2 \mathrm{ppm}$. The average worldwide lutetiun content in coal is 0.07 ppm (U.S. National Committee for Geochemistry, 1980).

Sharkey and others (1975) found that lutetium occurred in 38 percent of 13 U.S. raw coals analyzed, and that it ranged ln concentration from $<0.1$ to $0.3 \mathrm{ppm}$. The average U.S. lutetium content in coal is $0.08 \mathrm{ppm}$; for U.S. subbituminous coals, it averages $0.09 \mathrm{ppm}$, and for U.S. 1ignites, it averages 0.05 ppm (U.S. National Committee for Geochenlstry, I980). Gluskoter and others (1977) reported a geometric mean lutetlum content of 0.18 ppm in 14 Appalachian region whole-coal samples, 0.08 ppm in 56 Illinois basin whole-coal samples, and $0.05 \mathrm{ppm}$ in 22 Western U.S. whole-coal samples.

There is no avallable data on lutetlum concentrations in Alaska coals. 
PROFILE 37 - MAGNESIUM

Symbol: $\quad M g$

Atomic number: 12

Atomic welght: 24.312

\begin{tabular}{|c|c|c|}
\hline Alaska & $200-\frac{\cos 1}{6,000}$ & $\frac{\text { Ash }}{N, E}$ \\
\hline $\begin{array}{l}\text { U.S. } \\
\text { World }\end{array}$ & $\begin{array}{c}100-4,000 \text { Ppm } \\
\text { N.E. }\end{array}$ & $\begin{array}{c}0-25,000 \text { Ppm } \\
\text { N.E. }\end{array}$ \\
\hline
\end{tabular}

Magnesium is a metallic element contained malnly in the carbonate mineral group but found in assoctation with sllicate minerals. Tureklan and Wedepohl (1961) reported the following average magnesium concentrations in common sedimentary rocks: shales, 15,000 ppm; sandstones, 7,000 ppm; and carbonates, $47,000 \mathrm{ppm}$. Orheim (1979) cited the following clarke values for magnesium: earth's crust, 21,000 ppm; plant ash, 700 ppm; and water, $1,000 \mathrm{ppm}$.

Magnesium is a major Inorgantc constituent of coal. Magnesium oxide is one of the chlef components of coal ash.

\section{World Coals}

Abernethy and Gibson (1963) clted an average magnesium concentration in coal of 1,210 ppm. The U.S. National Comittee for Geochemistry (1980) reported a worldwide average magnesium content of 0.02 percent.

\section{United States Coals}

Sharkey and others (1975) found that magnesium occurred in 100 percent of 13 U.S. raw coals, and that it ranged in concentration from 500 to 3,500 $\mathrm{ppm}$. Others have reported a range in magnegium content in U.S. coals from 0.1 to 0.25 percent (Los Alamos Sclentiflc Laboratory, 1976; Wewerka and others, 1976). Swanson and others (1976) clted an average magnesium content of 0.1 percent in 601 U.S. coals. The U.S. National Commitee for Geochemistry (1980) reported an average magnesium content in U.S. coals of 0.12 percent. Magnesium ranges from 0 to 2.4 percent in ashes of U.S. coals (Los Alamos Sclentific Laboratory, 1976).

Appalachian regton. Swanson and others (1976) reported a geometric mean of 0.052 percent in 331 Appalachian region whole coal samples, and Gluskoter and others (1977) found a geometric mean of 0.05 percent in 23 Appalachisn coals.

Interior region. Swanson and others (1976) reported a geometric mean magnesium content of 0.063 percent in 194 Interlor whole-coal samples. Gluskoter and others (1977) Eound a geometric mean of 0.05 percent in 113 I111nois basin coals.

Western region. Swanson and others (1976) reported a geometric mean magnesium content of 0.245 percent in 93 Western region whole-coal samples 
and 0.17 percent in 34 Texas coals. Gluskoter and others (1977) found a geometric mean magnesium content of 0.12 percent in 29 Western U.S. coals.

\section{Alaska Coals}

Affolcer and others ( 1981 ) reported geometric mean magnesium concentrations of 0.21 percent, 0.37 percent, 0.13 percent, and 0.14 percent in whole-coal samples of healy (20), Kenai (10), Seldovia (34), and Utukok River (24) Quadrangles, respectively. Compared to 410 Powder River region coal samples, the magnesium content of healy Quadrangle coals is not significanty different, the magnesium content of Kenal Quadrangle coals is significantly higher, and the magnesium content of Seldovia Quadrangle coals is significantly lower. Compared with 295 Rocky Mountain province cosl samples, the magnesium concent of Utukok River Quadrangle coals is stgnificanty h1gher. 
PROFILE 38 - MANGANESE

Symbol: Nin

Atomic number: 25

Atomlc weight: $\quad 54.9380$

$\begin{array}{lll} & \text { Coal } & \text { Ash } \\ \text { Alaska } & 1-2 \frac{\text { As pm }}{90} & 30-7,500 \mathrm{ppm} \\ \text { U.S. } & 5-250 \mathrm{ppm} & 30-4,500 \mathrm{ppm} \\ \text { World } & 0-300 \mathrm{ppm} & 10-6,000 \mathrm{ppm}\end{array}$

Manganese is a metallic element found worldwide in the following minerals: pyrolusite $\left(\mathrm{MnO}_{2}\right)$, braunite $\left(\mathrm{Mn}_{2} \mathrm{O}_{3}\right)$, hausmannite $\left(\mathrm{Mn}_{3} \mathrm{O}_{4}\right)$, manganite $[\mathrm{MnO}(\mathrm{OH})]$, siderite $\left[\left(\mathrm{Fe},{ }^{2} \mathrm{Mn}\right) \mathrm{CO}_{3}\right]$, and calctte $\left[(\mathrm{Ca}, \mathrm{Mn}) \mathrm{CO}_{3}\right] .{ }^{3}$ Turekian and Wedepoh1 (1961) reported the following average ganganege concentrations in common sedimentary rocks: shales, $850 \mathrm{ppm}$; sandstones, XO ppm; and carbonates, $1,100 \mathrm{ppm}$. Orheim (1979) cited the following clarke values for manganese: earth's crust, 1,000 pp⿴; soll, $850 \mathrm{ppm}$, plant ash, 4,800 ppm; and water, $0.002 \mathrm{ppm}$.

Manganese generally occurs in coal in lower concentration than $15 s$ estimated average concentration in the earth's crust (Averitt, 1975). It is one of the elements of environmental concern in coal. It is typically inorganically combined in coal and concentrated in its mineral matter; thus, it is one of the elements showing least organic affinity. It is generally retained in high-temperature ash and over 95 percent in retained in low-temperature ash (Ruch and others, 1974).

World Coals

Abernethy and G1bson (1963) clted an average manganese content in coal of $33.8 \mathrm{ppm}$. The U.S. National Committee for Geochemistry (1980) reported an average worldwide manganese content of 0.005 percent.

\section{Undted States Coals}

Sharkey and others (1975) found that manganese occurred in 100 percent of 13 U.S. raw coals analyzed, and that 1 t ranged in concentration from 5 to $240 \mathrm{ppm}$. Others have cited a range in manganese content in U.S. coals from 6 to 181 ppm (Los Alamos Sclentiflc Laboratory, 1976; Wewerka and others, 1976). Swanson and others (1976) reported an average manganese concentration 1n 601 U.S. cools of 89.2 ppm. The U.S. National Committee for Geochemistry (1980) reported an average U.S. manganese content in coal of 0.01 percent. Los Alamos Sclentiflc Laboratory (1976) reported a range in manganese content of 30 to 1,800 ppm 1n ashes of U.S. coals and the following average concentrations by rank in ashes of U.S. coals: anthracites, $270 \mathrm{ppm}$; lowvolatile bicuminous, 280 PPm; medium-volatile bltuminous, 1,432 ppm; highvolatile bituminous, $120 \mathrm{ppm}$, and subbituminous and lignite, 688 PPm (Los Alamos Scientiflc Laboratory, 1976).

Appalachlan region. Swanson and others (1976) reported a geometric mean manganese content of $200 \mathrm{ppm}$ in 331 Appalachian region whole-coal samples. Gluskocer and others (1977) clted a geometric mean manganese content of 12 ppm in 23 Appalachian coals. 
Interior region. Swanson and others (1976) reported a geometric mean manganese content of $72 \mathrm{ppm}$ in 194 Interlor region whole-coal samples. Gluskoter and others (1977) cited a geometric mean manganese content of $40 \mathrm{ppm}$ in 113 Illinols basin coals.

Western region. Swanson and others (1976) reported a geometric mean manganese content of $34 \mathrm{ppm}$ in 93 Western region whole-coal samples and $51 \mathrm{PPD}$ in 34 Texas coals. Gluskoter and others (1977) clted a geometric mean manganese content of 28 ppm in 29 western U.S. coals.

\section{Alaska Coals}

Northern Alaska province. Conwell and Triplehorn (1976) found a manganese content of $590 \mathrm{ppm}$ in a Kukpuk River, Northern Alaska coal-ash sample and $40 \mathrm{ppm}$ in a Cape Thompson, Northern Alaska coal-ash sample. Affolter and others (1981) reported a range in manganese content of < 1.8 to $170 \mathrm{ppm}$ and a geometric mean manganese content of $16 \mathrm{ppm}$ in 54 Utukok River Quadrangle whole-coal samples.

Cook Inlet-Susitna province. Merritt (1985b) reported a mean manganese content of 36 ppu in 31 Matanuska Valley coal-ash samples. Affolter and others (1981) reported a range in manganese from 50 to 290 ppm and a geometric mean of 120 ppm in 10 Kenai Quadrangle whole-coal samples. They also found a range in manganese of 40 to 240 ppm and a geowetric mean of 90 ppm in 34 Seldovia Quadrangle whole-coal samples. Conwell (1977) c1ted a range in manganese concentration of 225 to $485 \mathrm{ppm}$ and a mean of $370 \mathrm{ppm}$ in seven Beluga field coal-ash samples. Merritt (1987a) reported a range of 72 to 7,430 ppm manganese and an average of 1,203 ppm manganese in 45 Susitna lowland coal-ash samples.

Nenana province. Affolter and others (1981) found a range in manganese content of 6.1 to $220 \mathrm{ppm}$ and a geometric mean of $46 \mathrm{ppm}$ in $20 \mathrm{Healy}$ Quadrangle whole-coal samples. Affolter and Stricker (1987) cited an average manganese content of $62 \mathrm{ppm}$ in ewo whole-coal samples of Seam No. 3, Usibelli Mine.

Alaska Peninsula province. Conwell and Trtplehorn (1978) reported an average manganese concentration of 339 ppm in elght Alaska Pentnsula coal-ash samples. 
PROF ILE 39 - MERCURY

Symbol: $\mathrm{Hg}$

$$
\begin{aligned}
& \text { Alaska } \\
& \text { U.S. } \\
& \text { World }
\end{aligned}
$$

Atomic number: 80

$$
\begin{aligned}
& 0.0 \frac{\operatorname{Cog} 1}{1-0.4} \mathrm{ppm} \\
& 0.01-10 \mathrm{ppm} \\
& \text { N.E. }
\end{aligned}
$$

Atomic weight: 200.59

$$
\begin{gathered}
\frac{\text { Ash }}{\text { N.E. }}<50-300 \text { ppm } \\
\text { N.E. }
\end{gathered}
$$

Mercury, commonly referred co as 'quicksilver,' Is a polsonous metallic element that is 1lquid at room temperature. It is often found in association with the mineral pyrite $\left(\mathrm{FeS}_{2}\right)$. Tureklan and Wedepohl (1961) reported the following average mercury concentrations in common sedimentary rocks: shales, $0.4 \mathrm{ppm}$; sandstones, $0.03 \mathrm{ppm}$; and carbonates, $0.04 \mathrm{ppm}$. Orhelm (1979) c1ted these clarke values for mercury: earth's crust, $0.08 \mathrm{ppm;} \mathrm{so11,} 0.01 \mathrm{ppm;}$ plant ash, $0.01 \mathrm{ppm}$; and water, $0.00003 \mathrm{ppm}$.

Mercury generally occurs in coal in appreciably greacer concentration than its estimated average concentration $1 n$ the earth's crust (Averitt, 1975). It shows a limfted enrichment factor of 2.25X in coal (U.S. National Comittee for Geochemlstry, 1980). Mercury is generally inorganically combined in coal and 1 s one of the elements showing least organic affinity (Ruch and others, 1974). It tends to be concentrated in the mineral matter or heavier specific gravity faction of coal (Cavallaro and others, 1978).

Mercury is potentially the most toxic substance in coal and coal ash (Berkowltz, 1979). It is one of the elements of chlef environmental concern in coal, and is toxic to plant and animal life at relatively low concentrations. Mercury may be released from coal-combustion sources, and up to 95 percent is lost in low-temperature ash (Ruch and others, 1974).

\section{World Coals}

Abernethy and Gibson (1963) cited an average mercury concentration in coal of $0.122 \mathrm{ppm}$. The U.S. National Comititee for Geochemistry (1980) reported a worldwide average mercury concentration in coal of $0.012 \mathrm{ppm}$.

\section{United States Coals}

Sharkey and others (1975) found that mercury occurred in 38 percent of 13 U.S. raw coals analyzed, and that it ranged in concentration from $<0.3$ to $0.5 \mathrm{ppm}$. Others have reported a range in mercury content in U.S. coals from 0.01 to $1.6 \mathrm{ppm}$ (Los Alamos Sclent1f1c Laboratory, 1976; Wewerka and others, 1976). Swanson and others (1976) reported an average mercury concentration In 601 U.S. coals of $0.1 \mathrm{ppm}$. The U.S. National Commttee for Geochemistry (1980) cited a U.S. average mercury concent in coal of 0.18 ppm. Mercury ranges from $<70-259$ ppm in ashes of U.S. coals (Los Alamos Scientific Laboratory, 1976).

Appolachian region. Swanson and others (1976) reported a geonetric mean mercury content of $0.14 \mathrm{ppm}$ in 331 Appalachian whole-coal samples. Gluskoter and others ( 1977 ) found a geometric mean mercury concent of 0.17 ppm in 23 Appalachian coals. 
Intertor region. Swanson and others (1976) reported a geometric mean mercury content of $0.10 \mathrm{ppm}$ in 194 Interfor reglon whole-coal samples. Gluskoter and others (1977) found a geometric mean mercury content of 0.16 ppm in 113 Illinols basin coals.

Western reg1on. Swanson and others (1976) reported a geometric mean mercury content of $0.06 \mathrm{ppm}$ in 93 Western region coals and 0.13 ppd in 34 Texas coals. Gluskoter and others (1977) found a geometrlc mean mercury content of 0.07 ppm in 29 Western U.S. coals.

\section{Alaska Coals}

Compared to other U.S. cosls, the content of mercury in Alaskan cosls is siatlar or lower.

Northern Alaska province. Conwell and Triplehorn (1976) determined that a Kukpuk River coal contalned 0.01 ppm mercury and a Cape Thompson coal contained 0.27 ppm mercury. Affolter and others (1981) reported a range 1n mercury concentration of 0.02 to $0.40 \mathrm{ppm}$ and a geometric mean of $0.04 \mathrm{ppm}$ in 54 Utukok River Quadrangle whole-coal samples.

Cook Inlet-Susitna province. Affolter and others (1981) reported mercury concentrations in 10 Kenai Quadrangle and 34 Seldovia Quadrangle whole-coal samples. They cited a range in mercury content in the Kenal Quadrangle coals from $0.0 \mathrm{I}$ to $0.12 \mathrm{ppm}$ and a geometric mean of $0.05 \mathrm{ppm}$. The range in the Seldovia Quadrangle coals was 0.03 to $0.40 \mathrm{ppm}$ mercury and a geowetric mean of 0.08 ppm mercury.

Conwell (1977) reported a range in mercury concentration of 0.02 to $0.07 \mathrm{ppm}$ and a mean of $0.04 \mathrm{ppm} 1 \mathrm{n}$ seven Beluga fleld whole-coal samples. Merrlet (1987a) clted a range of 20 to $490 \mathrm{ppb}$ mercury and an average of 106 ppb mercury in 66 Sualtna lowland coa1-ash samples.

Nenana province. Affolter and Stricker (1981) reported a range of 0.02 to $0.30 \mathrm{ppm}$ mercury and a geometric mean of $0.06 \mathrm{ppm}$ mercury in 20 Healy Quadrangle whole-coal samples. Affolter and stricker (1987) found an average of $0.10 \mathrm{ppm}$ mercury in two whole-coal samples of Sean No. 3, Ustbell1 Mine.

Alagka Peninsula province. Conwell and Triplehorn (1978) reported an average mercury concentration of $0.06 \mathrm{ppm}$ in elght Alaska Pentnsula whole-coal samples. 
PROFILE 40 - MOLYBDENUM

Symbol: Mo

Atomic number: 42

Atom1c weight: 95.94

\begin{tabular}{lll} 
& \multicolumn{1}{cc}{$\frac{\text { Col }}{1-15} \mathrm{ppm}$} & $10-10 \frac{\mathrm{Ash}}{0 \mathrm{ppm}}$ \\
Alaska & $0.0-75 \mathrm{ppm}$ & $0-3,000 \mathrm{ppm}$ \\
U.S. & $0-100 \mathrm{ppm}$ & $10-500 \mathrm{ppm}$
\end{tabular}

Molybdenum is a wetalif element that is generally assoclated with the sulfide mineral group, especially molybdenite (MoS ${ }_{2}$ ). Turekian and Wedepohl (1961) reported the following average molybdenum concentrations in common sedimentary rocks: shales, $2.6 \mathrm{ppm;}$ sandstones, $0.2 \mathrm{ppm}$; and carbonates, $0.4 \mathrm{ppm}$. Orhelm (1979) cited these clarke values for molybdenum: earth's crust, $1.7 \mathrm{ppm}$; so11, $2.5 \mathrm{ppm}$; plant ash, $13 \mathrm{ppm}$; and water, $0.01 \mathrm{ppm}$.

Molybdenum occura in coal in appreciably greater concentration than its estimated average concentration in the earth's crust (Averitt, 1961). It shows a limited enrichment factor of $2.0 \mathrm{X}$ in coal. Molybdenum is generally Inorganicaliy combined in coal and is one of the elements showing least organic affinity; it is concentrated in the mineral matter of coal (Ruch and ochers, 1974). In certain conversion processes, molybdenum in coal can act as a catalyst (Rao, 1976). About 33 percent of molybdenum is lost in high-temperature ash (Ruch and others, 1974).

\section{World Coals}

The U.S. National Comittee for Geochemistry (1980) cited a worldwide average molybdenum concentration in coll of 5 ppm. Berkowitz (1979) determined a maxtmum molybdenum concentration in coal ash of $500 \mathrm{gm} / \mathrm{ton}$ and an average molybdenum content of $200 \mathrm{gm} / \mathrm{ton}$.

\section{United States Coals}

Sharkey and others (1975) found that molybdenum occurred in 100 percent of 13 U.S. raw coals analyzed, and that it ranged in concentration from 1 to 5 ppD. Los Alamos Sclentific Laboratory (1976) reported a range in molybdenum content in U.S. coals of 0 to $73 \mathrm{ppm}$, and a range in ashes of U.S. coals of 0 to $2,900 \mathrm{ppm}$. Swanson and others (1976) c1ted an average molybdenum concentration of $1.5 \mathrm{ppm}$ in $601 \mathrm{U} . \mathrm{S}$. coals, and the U.S. National Committee for Geochemistry (1980) clted an average molybdenum content of 3 ppm 1a U.S. coals.

Appalachian regton. Swanson and others (1976) reported a geometric mean molybdenum content of 2 ppm 1n 331 Eastern U.S. coalg. Los Alamos Scientific Laboratory (1976) reported an average molybdenum concentrat1on of 3.5 ppm in 73 Appalachian region whole-coal samples. Gluskoter and others (1977) found a geometrtc mean molybdenum content of $1.8 \mathrm{ppm} 1 \mathrm{1a} 23$ Appalachian coals. 
Interior region. Swanson and others (1976) reported a geometric mean molybdenum content of 2 ppm in 194 Interfor reglon coals. Los Alamos Sclentific Laboratory (1976) cited an average molybdenum concentration of 4.3 ppm in 53 Eastern Interior region coals. Gluskoter and others (1977) found a geometric mean molybdenum content of 6.2 ppm in 111 Illinois basin whole-coal samples.

Western region. Swanson and others (1976) reported a geometrtc mean molybdenum content of $1.5 \mathrm{ppm}$ in 93 Western region coals and $0.7 \mathrm{ppm}$ molybdenum in 34 Texas coals. Los Alamos Scientific Laboratory (1976) c1ted an average molybdenum content of $3.1 \mathrm{ppm}$ in 48 Western and Southwegtern Interlor region coals and $1.7 \mathrm{ppm}$ in 51 Northern Great Plains region coals. Gluskoter and others (1977) found a geometric mean molybdenum content of 0.59 ppm in 29 Western U.S. whole-coal samples.

\section{Alaska Coals} 1s low.

Compared to other U.S. coals, the content of molybdenum in Alaskan coals

Northern Alaska province. Conwell and Trlplehorn (1976) found 70 ppm molybdenum in a Kukpuk River coal-ash sample and 100 ppm molybdenum in a Cape Thompson coal-ash sample. Rao (1980) found a range in molybdenum content of 0.3 to $23 \mathrm{ppm}$ and a mean of $1.2 \mathrm{ppm}$ in 38 Cape Beaufort regton whole-coal samples. He reported a range in molybdenum content of 2.0 to $10 \mathrm{ppm}$ and a mean of $5.9 \mathrm{ppm}$ in ash samples of the same coals. Rao (1980) concluded that the concentration of molybdenum in Cape Beaufort region coals was quite low compared to other U.S. coals. Rao and Wolff (1981) clted a molybdenum content of $0.92 \mathrm{ppm}$ in a whole-coal sample of a Meade River subbituminous $B$ seam, and $2 \mathrm{l}$ ppm molybdenum in an ash sample of the same coal. Affolter and others (1981) reported a range in molybdenum content of 0.2 to 1.5 ppm and a geometric mean of $0.07 \mathrm{ppm}$ in 54 Utukok River Quadrangle whole-coal samples.

Cook Inlet-Susitna province. Merritt (1985b) reported a mean molybdenum content of $6.2 \mathrm{ppm}$ in 29 Matanuska Valley coal-ash samples. Rao and Wolf $f$ (1981) found a molybdenum concent of 1 to $6 \mathrm{ppm}$ in a whole-coal sample of the subbituminous C-ranked Cabin bed, Kenai fleld; an ash sample of the same coal contained $14 \mathrm{ppm}$ molybdenum. Affolter and others (1981) reporced a range in molybdenum content of 1.5 to 5 ppm and a geometric mean of 3 ppm in 10 Kenai Quadrangle whole-coal samples. They also reported a range in molybdenum concent of $<0.5$ to $15 \mathrm{ppm}$ and a geometric mean of $1.5 \mathrm{ppm}$ in 34 Seldovia Quadrangle whole-coal samples. Conwell (1977) found a range in molybdenum content of 15 to $150 \mathrm{ppm}$ and a mean of $44 \mathrm{ppm}$ In seven Beluga fleld coal-ash samples. Rao and Wolff (1981) reported molybdenum concentrations in a Ilgnitlc coal of the upper bench, Sunflower Creek seam, Yentna fleld; a whole-coal sample contalned $0.34 \mathrm{ppm}$ molybdenum and a coal-ash sample contained $10 \mathrm{ppm}$ molybdenum. Merrice (1987) found a range in molybdenum content of 2 to $175 \mathrm{ppm}$ and an average of $19 \mathrm{ppm}$ in 65 Susitna lowland coal-ash samples. 
Nenana province, Rao and Wolff (1981) reported a molybdenum content of $2.5 \mathrm{ppm}$ In a whole-coal sample of the subbltuminous C-ranked No. 4 seam from the Nenana bas1n; an ash sample of the same coal contained 17 ppm molybdenum. Affolter and others (1981) reported a range in molybdenum content of 0.7 to 3 ppm and a geometric mean of 1.5 ppm in 20 Healy Quadrangle whole-coal samples. Merritt (1985a) noted a general factor of enrichment for molybdenum of 17X based on Nenana basin coal-ash samples. Affolter and Stricker (1987) found an average molybdenum content of $0.9 \mathrm{ppm}$ in two whole-coal samples of seam No. 3, Usibelil Mine.

Rao and Wolff (1981) reported molybdenum contents of 11 ppm and 94 ppm in whole-coal and coal-ash samples, respectively, of a subbituminous C-ranked seam from Oher Creek, Jarvis Creek fleld. They also cited molybdenum contents for the subbituminous C-ranked main seam from the Little Tonzona River fleld, western Nenana province; a whole-coal sample contained 11 ppm molybdenum and a caal-ash sample contained 79 ppm molybdenum.

Alaska Pentnsula province. Conwell and Triplehorn (1978) reported an average molybdenum concentration of 56 ppm in elght Alaska Peninsula coal-ash samples. 


$\begin{array}{lcc} & \frac{\text { CoaI }}{\text { N.E. }} & \frac{\text { Ash }}{\text { N.E. }} \\ \text { Alaska } & 3-40 \mathrm{Ppm} & \text { N.E. } \\ \text { World } & 0-50 \mathrm{ppm} & \text { N.E. }\end{array}$

Neodymium is a metallic rare-earth element. Tureklan and WedepohI (1.961) reported the following average neodymlum concentrations in common sedimentary rocks: shales, $24 \mathrm{ppm}$; sandstones, $37 \mathrm{ppm}$, and carbonates, $4.7 \mathrm{ppm}$. The average worldwide neodymium content in coal is $4.7 \mathrm{ppm}$ (U.S. Nationa1 Committee for Geochemistry, 1980).

Sharkey and others (1975) found that neodymium occurred in 100 percent of 13 U.S. raw coals amelyzed, and that 1 t ranged $1 \mathrm{n}$ concentration from 4 to $36 \mathrm{ppm}$. The U.S. National Committee for Geochemistry (1980) found that the average U.S. neodymium content in coal is $37 \mathrm{ppm}$; in addition, for U.S. subbituminous coals, it averages $50 \mathrm{ppm}$, and for U.S. 11gnites, it averages $11 \mathrm{PPm}$.

Merritt (1985b) reported a mean neodymium concentration of 6 ppm in ash samples of 29 Matanuska Valley coals. 
PROFILE 42 - NICKEL

Symbo1: N1 Atomlc number: 28

Atomic welght: 58.71

\begin{tabular}{ll} 
& \multicolumn{1}{c}{ Coal } \\
A.laska & $3-6 \overline{0 p q}$ \\
U.S. & $0.5-110 \mathrm{ppm}$ \\
World & $0-100 \mathrm{ppm}$
\end{tabular}

$$
\begin{aligned}
& \text { Ash } \\
& 50-30 \widetilde{0 P p m} \\
& 0-1,200 \mathrm{ppm} \\
& 10-3,000 \mathrm{ppm}
\end{aligned}
$$

Nickel is a hard and ductile ferromagnetic metallic element. It is found in millerite (N1S) and in intimate association with pyrite ( $\mathrm{FeS}_{2}$ ). Tureklan and Wedepohl (1961) reported the following nfckel concentrations in common sedimentary rocks: shales, $68 \mathrm{ppm}$; sandstones, $2 \mathrm{ppm}$; and carbonates, $20 \mathrm{ppm}$. Orheim (1979) c1ted these clarke values for nickel: earth's crust, 75 ppm; so11, 40 ppm; plant ash, 65 ppm; and water, 0.002 ppm.

Nickel generally occurs in coal in appreciably greater concentration that its estimated average concentration in the earth's crust (Avertte, 1975). It is one of the elements assoclated with both organic and inorganic matter, but is more closely allied with the inorganic, heavier speciflc gravity fractiong of coal (Ruch and others, 1974; Cavallaro and others, 1978).

Nickel is one of the elements of environmental concern in coal. It can be enrlched on the surfaces of fly-ash particles released from coal-fired plants (Mraw and others, 1983). Nickel is generally retalned in hightemperature ash, and over 95 percent is retalned in low-temperature ash (Ruch and others, 1974).

\section{World Coals}

Abernethy and Gibson (1963) cited an average nickel concentration in coal of $16 \mathrm{ppm}$. The U.S. National Comittee for Geochemistry (1980) reported a worldwide average nickel content in coal of 15 ppm. Berkowltz (1979) reported a maximum nickel concentration in coal ash of $8,000 \mathrm{gm} / \mathrm{ton}$ and an average nickel concentration of $700 \mathrm{gm} / \mathrm{ton}$.

\section{United States Coals}

Sharkey and others (1975) found that nickel occurred in 100 percent of 13 U.S. raw coals, and that it ranged in concentration from 3 to 60 ppm. others have clted a range in alckel content in U.S. coals from 0.4 to 104 ppw (Los Alamos Scientific Laboratory, 1976; Wewerka and others, 1976). Swanson and others (1976) reported an average nlckel content of 12.5 ppm in 601 U.S. coals. The U.S. National Committee for Geochemlatry (1980) clted an average nlckel concentration in coal of $15 \mathrm{ppm}$. Nickel ranges in content from 0 to 1,200 ppm in ashes of U.S. coals, and exhiblts the following average concentrations by rank in coal ashes: anthracties, 220 ppa; low-volatile bituminous coals, 141 pp⿴; medium-volatile bituminous coals, 263 ppm; highvolatile bituminous coals, $154 \mathrm{ppm}$; and subbituminous coals and lignites, 129 ppm (Los Alamos Sclentific Laboratory, 1976). 
Appalachian region. Swanson and others (1976) reported a geometric mean nickel concentration of 15 ppm in 331 Appalachlan region whole-coal samples. Los Alamos Scientific Laboratory (1976) reported an average concentration of 14 ppm in 73 Appalachian region coals. Gluskoter and others (1977) found a geometric mean nickel concentration of 14 ppm in 23 Appalachtan coals.

Interior region. Swanson and others (1976) reported a geometric mean nickel content of $18 \mathrm{ppm}$ in 194 Interior region whole-coal samples. Los Alamos Sclentific Laboratory (1976) reported an average nickel content of $15 \mathrm{ppm}$ in 53 Eastern Interior coals. Gluskoter and others (1977) cited a geometric mean nickel content of $19 \mathrm{ppm}$ in 113 Illinols basin whole-coal samples.

Western region. Swanson and others (1976) reported a geometric mean nickel content of 2 ppm in 93 Westera region whole-coal samples and 15 ppm in 34 Texas whole-coal samples. Los Alamos Sclentiflc Laboratory (1976) cited an average nickel content of $14 \mathrm{ppm}$ in 48 Western and Southestern Interfor region whole-coal samples and 7.2 ppm 1n 51 Northern Great Pla1ns region coals. Gluskoter and others (1977) cited a geometric mean alckel content of 4.4 ppm $1 \mathrm{n} 29$ Western U.S. coals.

\section{Alaska Coals}

There exists an abundant amount of geochemical data relating to nickel concentrations in Alaska coals and coal ashes. Compared to other U.S. coals, the content of nickel in Alaskan coals is generally higher.

Northern Alaska province. Rao (1968) reported an average concentration of 7.3 ppm nickel in 12 Northern Alaska whole-coal samples; ash samples of the same coals contained an average of $80 \mathrm{pPm}$ lead. Conwell and Triplehorn (1976) found an average content of $1,500 \mathrm{ppm}$ in a Kukpuk River coal-ash sample and $70 \mathrm{ppm}$ in a Cape Thompson coal ash sample. They concluded that the Kukpuk Rlver sample contalned anomalously high concentrations of nickel. Roo (1980) analyzed and reported on nickel concentrations in some 38 Cape Beaufort region whole-coal and coal-ash samples. He concluded that although certain of the Cape Beaufort region coals showed high concentrations of nickel, its average concentration was quice low compared to other U.S. coals. In the raw coals, nickel ranged from 2.5 to 23 ppm and had a mean content of $8.1 \mathrm{ppm}$; in the coal-ash samples, nickel ranged from 10 to $106 \mathrm{ppm}$ and had a mean content of $41 \mathrm{ppm}$ (Rao, 1980). Rao and Wolff (1981) found $4.9 \mathrm{ppm}$ nickel in a whole-coal sample of a subbituminous $B$ seam from the Wainwright fleld, Northern Alaska; ash of the same coal contained 102 ppm nickel. They reported a whole-coal nickel content of $21 \mathrm{ppm}$ in a subbltuminous $B$ seam from Meade River, Northern Alaska; ash of the same coal contalned 260 ppm nickel. Additionally, they cited a whole-coal lead content of 33 ppm in a highvolatyle bituminous seam from Sagwon Bluffs, Northern Alaska; ash of this coal contalned $60 \mathrm{ppm}$ nlckel (Rao and Wolff, 1981). Affolter and others (1961) reported a range in nickel concentration of 3 to 30 ppm for 54 Utukok RIver Quadrangle whole-coal samples and a geometric mean content of $1.7 \mathrm{ppm}$. 
Cook Inlet-Sustina province. Rao (1968) reported an average nickel content of 22.8 ppm in 22 Matanuska Valley whole-coal samples and an average nickel content of $181 \mathrm{ppm}$ in ash samples of the same coals. Rao and Wolff (1981) found a nickel content of 18 ppm in a whole-coal sample of the highvolatile bituminous lower seam, Castle Mountaln mine, Matanuska field; an ash sample of the same coal concained $90 \mathrm{ppm}$ nickel. They also reported a nickel content of $58 \mathrm{ppm}$ in a whole-coal sample of a high-volatile bituminous seam from the Premler mine, Matanuska fleld; an ash sample of this coal contained 200 ppm nickel. Merritt (1985b) found a mean nickel concentration of 7 ppm In 31 Matanuska Valley coal-ash samples.

Rao (1968) reported an average nlckel content of 7.3 ppm in elght Kenal field whole-coal samples; ash samples of the same coals contatned an average 69 ppm nickel. Rao and Wolff (1981) found a nickel content of $13 \mathrm{ppm}$ in a whole-coal sample of the subbituminous C-ranked Cabin bed, Kenal fleld; an ash sample of the coal showed $105 \mathrm{ppm}$ nickel. Affolter and others (1981) reported a range in nickel content from 7 to $20 \mathrm{ppm}$ in 10 Kenal Quadrangle whole-coal samples, and a geometric mean nickel content of 10 ppm. Additionally, they cited a range in nickel content from 5 to 20 ppm in 34 Seldovia Quadrangle whole-coal samples, and a geometric mean nickel content of $10 \mathrm{ppm}$. Merritt and others (1987) cited a mean nickel concentration of 166 ppm in ash samples of 31 Kenat field coals.

Conwell (1977) reported a range in nickel content from 70 to 100 ppm and a mean content of 87 ppm in seven Beluga fleld coal-ash samples. Rao and Wolft (1981) reported a nickel content of $19 \mathrm{ppm}$ in a whole-coal sample of the subbltumlnous C-ranked Waterfall seam, Beluga fleld; and ash sample of the same coal contained 121 ppm nickel. They also reported a nickel content of 5.0 ppm (whole-coal basis) in a Sunflower Creek lignite Erom the Yentna fleld; an ash sample of the same coal contained 148 opm nickel. Merritt (1987a) found a range in nickel content from 39 to 709 ppm and an average content of $162 \mathrm{ppm}$ for ash samples of 45 Susitna lowland coals. Rao and Smith (1987) reporeed nickel concentrations in flve coal seams from the Chuitna district, Beluga fleld. Average nickel contents decrease downsection as follows: Blue Seam (15 samples), 200 ppm; Red 3 Seam ( 13 samples), 180 ppm; Red 2 Seam (26 samples), 157 ppm; Red 1 Seam (16 samples), 102 ppm; and Purple Seam ( 5 samples), $86 \mathrm{ppm}$.

Rao and Wolff (1981) snalyzed a Ilgnite seam from Coal Creek, Broad Pass fleld. A raw coal sample showed a nickel content of $35 \mathrm{ppm}$, and a coal-ash sample contalned 124 ppo ntckel.

Nenana province. Rao (1968) reported an average nickel concentration of $4.8 \mathrm{ppm}$ in 25 Nenana basin whole-coal samples; ash samples of the coals contalned an average 51 ppm nickel. Rao and Wolfe (1981) analyzed seven samples of five different seams, lncluding the No. 2, No. 4, No. 6 (three splits, top, middle, and lower), Moose, and Caribou seams, all of subbituminous $C$ rank. The whole-coal samples contalned an average nickel content of 20 ppm and the coal-ash samples contalned an average nickel content of $128 \mathrm{ppm}$. Affolter and others (1981) cited a range of 5 to $30 \mathrm{ppm}$ nlckel in 20 Healy Quadrangle whole-coal samples and a geometrlc mean nickel content of 10 ppm. Affolter and Stricker (1987) found an average 6.9 ppm nickel in 
two whole-coal samples of seam No. 3, Usibell1 Mine. Merritt (1985a) reported a general factor of enrichment for nlckel of $1.6 \mathrm{X}$ based on Nenana basin coal-ash samples.

Rao (1968) reported an average nickel concentration of $2.6 \mathrm{ppm}$ in three Jarvis Creek field whole-coal samples; ash samples of the same coals revealed an average nickel content of 26 ppm. Rao and Wolff (1981) cited a nickel concent of 19 ppra in a whole-coal sample of an Ober Creek subbiturinous C-ranked seam, Jarvis Creek field; an ash sample contalned 145 ppm nickel. Belowich (1987) found an average nickel content of $21 \mathrm{ppm}$ in 27 Jarvis Creek fleld whole-coal samples.

Rao and Wolff (1981) also analyzed the subbituminous C-ranked main seam of the Little Tonzona River fleld, western Nenana province. A whole-coal sample contained $25 \mathrm{ppm}$ nickel, and a coal-ash sample contalned $175 \mathrm{ppm}$ nickel.

Alaska Peninsula province. Conwell and Triplehora (1978) cited an average nlckel concentration of $37 \mathrm{ppm}$ in eight Alaska Peninsula coal-ash samples.

Gulf of Alaska province. Rao (1968) reported an average nickel content of $3.2 \mathrm{ppm}$ in five Berlng River field whole-coal samples and an average 131 ppm nickel in ash samples of the same coals. Smith and Rao (1987) c1ted an average concentration of $273 \mathrm{ppm}$ nickel to 20 Bering River field coal-ash samples.

Yukon-Koyukuk province. Rao and Wolff (1981) c1ted a whole-coal nickel concentration of $26 \mathrm{ppm}$ and a coal-ash nickel concentration of $79 \mathrm{ppm}$ in a high-volatile bituminous sean of the Tramway Bar field. 


\section{PROFILE 43 - NIOBIUM}

Symbol: $\mathrm{Nb}$

Atomic number: 41

Atomle welght: 92.906

$\begin{array}{ll} & \frac{\text { Coal }}{\text { Alaska }} \\ \text { U.S. } & 0.5-10 \mathrm{ppm} \\ \text { Worid } & \mathrm{S}-50 \mathrm{ppm} \\ & \text { N.E. }\end{array}$

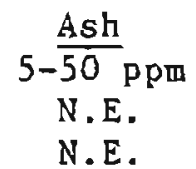

Niobium is a ductile metallic element that occurs chiefly in columbite $\left[(\mathrm{Fe}, \mathrm{Mn}) \mathrm{Nb}_{2} \mathrm{O}_{6}\right]$. Tureklan and Wedepohl (1961) reported the following average nlobium concentrations in common sedimentary rocks: shales, 11 pp; sandstones, 0.0X ppm; and carbonates, $0.3 \mathrm{ppm}$. Orheim (1979) cited these clarke values for nloblum: earth's crust, $20 \mathrm{ppm}$; soll, $15 \mathrm{ppm}$; and plant ash, $0.3 \mathrm{ppm}$.

\section{Untted States Coals}

Sharkey and others (1975) found that niobium occurred in 100 percent of 13 U.S. raw coals analyzed, and that it ranged in concentration from 5 to 41 ppm. The U.S. National Committee for Geochemistry (1980) c1ted an average nioblum concentration in 799 U.S. coals of 4.5 ppm. Swanson and others (1976) reported an average niobium content of $2.2 \mathrm{ppm}$ in $60 \mathrm{l}$ U.S. coals; they also found that lignites showed a lower average concentration of nioblum $(2.7 \mathrm{ppm})$ than subbituminous coals $(5.4 \mathrm{ppm})$. Additionally, they cited the following geometric mean nioblum concentrations in whole-coal samples of the U.S. by region: Eastern U.S. (331), 3 ppm; Intertor region (194), 0.7 ppm; Western regton (93), 3 ppm; and Texas (34), 2 ppm.

\section{Alaska Coa1s}

Compared to other U.S. coals, the content of niobium in Alaska coals is stmilar.

Northern Alaska province. Conwell and Triplehorn (1976) found niobium contents of 50 ppm in Kukpuk River and Cape Thompson coal-ash samples. Affolter and others (1981) reported a range in nloblum content of 0.7 to $10 \mathrm{ppm}$ in 54 Utukok River Quadrangle whole-coal samples and a geometric mean of 0.5 ppm.

Cook Inlet-Susitna province. Merritt (1985b) found a mean nioblum content of 9 ppm in 31 Matanuska Valley cosl-ash samples. Affolter and others (1981) reported a range in niobium content of $<2$ to $7 \mathrm{ppm}$ and a geometric mean of $3 \mathrm{ppm}$ in 10 Kenat Quadrangle whole-coal samples. In addition, they found a range of $<1.5$ to 5 ppm nioblum and a geometric mean of $0.7 \mathrm{ppm}$ nlobium in 34 Seldovia Quadrangle whole-coal samples. ConwelI (1977) reported a range of 20 to $30 \mathrm{ppm}$ nioblum and a mean of $23 \mathrm{ppm}$ niobium in seven Beluga field coal-ash samples.

Nenana province. Affolter and otbers (2981) reported a range of $<1.5$ to 7 ppm alobium and a geomerric mean of 1.5 ppm nioblum in 20 Healy quadrangle whole-coal samples. Affolter and Stricker (1987) found an average niobium content of 1.0 ppr in two wholercoal samples of Seam No. 3, Usibell1 Mine. 
Nitrogen is a nometallic element that occurs $8 s$ an almost inert diatomlc gas $\left(\mathrm{N}_{2}\right)$; it composes approximately 80 percent of alr by volume. It belongs to the organic mineral group of elements in coal (Wewerka and others, 1978).

Nitrogen constlutes part of the ultimate coal analysis. Nitrogen can be considered an lmpurity of coal along with sulfur, iron, and other inorgantcs. Gluskoter and others (1977) reported a geometric mean nitrogen content of 1.3 percent in 22 Appalachian region whole-coal samples, 1.3 percent in 110 Illinois basin whole-coal samples, and 0.98 percent in 22 Western U.S. whole-coal samples.

Alaska coals are similar in nitrogen composition to other U.S. coals when considered by rank. For example, a high-volatile a bituminous coal from the Matanuska Valley contains about 1.6 percent nitrogen, whereas Nenana and Beluga subbituminous coals contain 0.6 percent nitrogen (equilibrium bed molsture basts). 
PROFILE 45 - OSMIUM

Syobol: Os

Atomic number: 76

Atomic weight: 190.2

$\begin{array}{lcc} & \text { Coal } & \text { Ash } \\ \text { Alaska } & \text { N.E. } & \text { N.E. } \\ \text { U.S. } & <0.2 \mathrm{ppm} & \text { N.E. } \\ \text { World } & \text { N.E. } & \text { N.E. }\end{array}$

Osmium is a hard metallic element found in small quantities in ores of osmirldium, nickel, and platinum. Sharkey and others (1975) found that osmium contents were $<0.2 \mathrm{ppm}$ in $13 \mathrm{U}$.S. raw coals analyzed. Somerville and Elder (1977) reported an osmium content below the $0.1 \mathrm{ppm}$ detection limit in North Dakota lignites.

There is no avallable data on osmlum concentrations in Alaska coals. 
PROFILE 46 - OXYGEN

Symbol: 0

Atomic number: 8

Atomic weight: 15.9994

Alaska
U.S.
World

Coal

$\underline{\text { Ash }}$

$110,00 \overline{0-450,000 \mathrm{ppm}}$

$\overline{--}$

$40,000 \sim 220,000 \mathrm{ppm}$

$40,000-480,000 \mathrm{ppm}$

$-$

Oxygen is a gaseous element constituting about 20 percent of the atmosphere by volume. It combines readily with most elements and is required for all combustion processes.

Oxygen forms a pare of the ultimate coal analysis. Gluskoter and others (1977) reported a geowetric mean nitrogen content of 7.0 percent in 22 Appalachian region whole-coal samples, 8.0 percent in 109 Ilinnols basin whole-coal samples, and 17.0 percent in 29 Western U.S. whole-cosl samples.

High-rank Alaskan coals are similar in oxygen content to other U.S. coals of similar rank. For example, a high-volatile A bituminous coal from the Matanuska Valley contalns about 6.1 percent oxygen. Low-rank Alaska coals, as Nenana and Beluga subbituminous coals, contain about 35.0. percent axygen (equilibrium bed molsture basis), an amount significantly higher than other U.S. coals of similar rank. 


\section{PROFILE 47 - PALLADIUM}

Symbol: Pa

Atomic number: 46

Atomic weight: 106.4

$\begin{array}{lcc} & \frac{\text { Coal }}{\text { N.E. }} & \text { Ash } \\ \text { Alaska } & <0.1 \text { ppm } & \text { N.E. } \\ \text { U.S. } & \text { N.E. } & \text { N.E. } \\ \text { World } & \text { N.E. }\end{array}$

Palladium is a metalif element occurring naturaliy with platinum, most commonly in ores of gold, nickel, and copper. It is used as a catalyst in hydrogenation processes. Sharkey and others (1976) found that palladium content was $<0.1$ Ppm in 13 U.S. raw coals analyzed. Somerville and Elder (1977) found that palladium content was below the detection limit of 0.1 ppm in North Dakota 11 gnites.

There is no avallable data on palladfum concentrations in Alaska coals and coal ashes. 
PROFILE 48 - PHOSPHORUS

Symbol: $P$

Atomic number: 15

Atomic weight: 30.9738

$\begin{array}{lc} & \frac{\text { Coa } 1}{2,400 \mathrm{ppm}} \\ \text { Alaska } & 30-2,500 \mathrm{ppm} \\ \text { U.S. } & 5-1,5 . \mathrm{N}\end{array}$

Phosphorus is a highly reactive, polsonous, nonmetallic element that occurs naturally in phosphate minerals, especlally apatite $\left[\mathrm{Ca}_{5}\left(\mathrm{PO}_{4}\right)_{3}\left(\mathrm{~F}, \mathrm{CO}_{3}\right)\right]$ and fluorapatite $\left[\mathrm{Ca}_{5}\left(\mathrm{PO}_{4}\right)_{3},(\mathrm{~F}, \mathrm{OH})\right]$. Turekian and Wedepoh 1 (1961) reported the following average phosphorus concentrations in common sedimentaxy rocks: shales, $700 \mathrm{ppm}$; sandstones, $170 \mathrm{Ppm}$; and carbonates, $400 \mathrm{ppm}$. Orhelm (1979) reported these clarke values for phosphorus: earth's crust, $100 \mathrm{ppm}$; so11, $40 \mathrm{ppm}$; plant ash, $65 \mathrm{ppm}$; and water, 0.07 ppar.

Although it generally occurs in lower concentration than its estimated average concentration in the earth's crust (Aver1tt, 1975), phosphorus can be a major element in the mineral constituents of coal. Phosphorus is one of the elements associated with both organic and inorganic matter, although $1 t$ is more closely allied with organic fractions (Ruch and others, 1974).

\section{World Coals}

The U.S. National Committee for Geochemistry (1980) cited a worldwide average phosphorus content in coal of 0.05 percent.

\section{Unfted States Coals}

Sharkey and others (1975) Eound that phosphorus occurred in 100 percent of 13 U.S. raw coals analyzed, and that it ranged in concentration Exom 6 to $310 \mathrm{ppm}$. Elsewhere, phosphorus has been reported to range in U.S. coals from 5 to 1,430 ppm and in the ashes of U.S. coals from <440 to 3,360 ppm (Los Alamos Sclentific Laboratory, 1976). Gluskoter and others (1977) cited the following geometric mean phosphorus concentrations in U.S. whole-coal samples by region: Appalachian region (23), 81 ppm; Illinois basin (113), 45 ppm; and Western region (29), 82 ppw.

\section{Alaska Coals}

Affolter and others (1981) reported geometric mean iron concentrations of 0.003 percent, 0.04 percent, 0.03 percent, and 0.03 percent in whole-cos 1 samples of the Healy (20), Kenai (10), Seldovia (34), and Utukok River (54) Quadrangles, respectively. Merritt (1985b) clted a mean phosphorus content of 319 ppm in six Matanuska Valley coal-ash samples. 


\section{PROFILE 49 - PLATINUM}

Symbo1: Pt Atomic number: 78

Atom1c we1ght: 195.09

\begin{tabular}{|c|c|c|}
\hline & Coal & Ash \\
\hline Alaska & $<0.1 \mathrm{ppm}$ & $\overline{\mathrm{N} . \mathrm{E}}$. \\
\hline U.S. & $<0.3 \mathrm{ppm}$ & N.E. \\
\hline World & < 1 ррш & N.E. \\
\hline
\end{tabular}

Platinum is a metallic element found worldwide, commonly occurring in ores with other metals as irldium, osmium, and nickel. Platinum does not oxidize in a1r. Orhelm (1979) reported a clarke value for platinum 1n the earth's crust of $0.005 \mathrm{ppm}$. Berkowitz (1979) found that platinum's maximum concentration in coal ash was $0.7 \mathrm{gm} /$ ton. Sharkey and others (1975) found that platinum content was $<0.3 \mathrm{ppm}$ in $13 \mathrm{U.S}$. raw coals analyzed. Somerville and Elder (1977) reported that platinum was below the 0.1 ppm detection limlt In North Dakota lignites. Conwell and Trlplehorn (1976) found the concentration of platinum to be below the detection 11mit in ash samples of two Northern Alaska coals from Kukpuk River and Cape Thompson. 


$$
\text { PROFILE } 50 \text { - POTASSIUM }
$$

Symbol: $K$

$\begin{array}{lcc} & \frac{\text { Coal }}{14,000 \mathrm{ppm}} & \frac{\text { Ash }}{\mathrm{N} . \bar{E}} . \\ \text { Alaska } & 100-7,000 \mathrm{ppm} & 6,000-15,000 \mathrm{ppm} \\ \text { U.S. } & 100-7.0 . & \text { N.E. } \\ \text { World } & \text { N.E. } & \end{array}$

Potassium is a highly reactive or explostve element that is mainly contained in the aluminosilicate mineral group. Turektan and Wedepohl (1961) reported the following average potasslum concentrations in common sedimentary rocks: shales, $26,600 \mathrm{ppm}$; sandstones, $10,700 \mathrm{ppm}$; and carbonates, 2,700 ppm.

Potassium is a major inorganic elewent in the mineral constituents of coal, and potasslum oxide is one of the maln constituents of coal ash. Potassium has an important effect on the use of coal in combustion and cokemaking.

\section{World Coals}

Abernethy and Gibson (1963) cited an average potassium concentration in coal of 1,540 ppor. The U.S. National Committee for Geochemistry (1980) reported a worldwide average pocassium content in coal of 0.01 percent.

\section{United States Coals}

Sharkey and others (1975) found that potassium occurred in 100 percent of 13 U.S. raw coals analyzed, and that it ranged in concentration from 300 to 6,500 $\mathrm{pPm}$. Elsewhere, phosphorus has been found to range in concentration 1n U.S. coals from 0.02 to 0.43 percent (Los Alamos Sclentific Laboratory, 1976; Wewerka and others, 1976). Swanson and others (1976) reported an average potassium content of 0.1 percent in 601 U.S. coals. The U.S. National Committee for Geochemistry (1980) cited an average potassium content in U.S. coals of 0.18 percent, and the following average potassium concentrations by rank: anthracites, 0.24 percent; bituminous coals, 0.21 percent; subbituminous coals, 0.06 percent; and 1 ignites, 0.20 percent. Ashes of U.S. coals show a range in potassium content of 0.66 to 1.32 percent (Los Alamos Sclent1fic Laboratory, 1976).

Appalachlan reglon. Swanson and others (1976) reported a geometric mean potassium content of 0.13 percent in 331 Appalachian region whole-coal samples. Gluskoter and others (1977) cited a geometric mean of 0.21 percent poragstum in 23 Appalachian region coals.

Intertor regton. Swenson and others (1976) reported a geometrlc mean potassium coatent of 0.11 percent in 194 Interfor region whole-coal samples. Giuskoter and others (1977) cited a geometric mean of 0.16 percent potassium in 113 Illinots bastn coals. 
Western reglon. Swanson and others (1976) reported a geometric mean potassium content of 0.028 percent in 93 Western region whole-coal samples and 0.15 percent in 34 Texas coals. Gluskoter and others (1977) cited a geometric mean of 0.03 percent potassium in 29 Western U.S. coals.

\section{Alaska Coals}

Affolter and others (1981) reported geometric mean potassium concentrations of 0.091 percent, 0.14 percent, 0.16 percent, and 0.07 percent in whole-coal samples of the Healy (20), Renal (10), Seldovia (34) and Utukok River (54) Quadrangles, respectively. Compared to potassium contents in 410 Powder Rlver region and 295 Rocky Mountala province coal samples, the porassium content of these Alaskan coals is significantly higher. Based on samples of $s 1 x$ coal beds from the Tyonek Formation, Beluga fleld, Affolter and Stricker (1984) found that the concentration of potasslum varled directly with the ash content of the coals. 


$\begin{array}{lc} & \frac{\text { Coal }}{\text { N.E. }} \\ \text { Alaska } & 1-10 \mathrm{PPI} \\ \text { U.S. } & 0-10 \mathrm{PPm} \\ \text { World } & \end{array}$

$$
\begin{aligned}
& \frac{\text { Ash }}{10} \text { PPm } \\
& \text { N.E. } \\
& \text { N.E. }
\end{aligned}
$$

Praseodymium is a rare-earth element. Turekian and Wedepoh1 (1961) reported the following average praseodymium concentrations in common sedimentary rocks: shales, 5.6 ppm; sandstones, $8.8 \mathrm{ppm}$; and carbonates, 1.l ppm. The U.S. National Committee for Geochemistry (1980) clted a worldwide average praseodymium concentration in coal of 2.2 ppm.

Sharkey and others (1975) found that praseodymium occurred in 100 percent of 13 U.S. raw coals analyzed, and that it ranged in concentration from 1 to $8 \mathrm{ppm}$. The U.S. average praseodymium content in coal is 2.7 ppa; for U.S. subbituminous coals, it is $6.1 \mathrm{ppm}$, and for U.S. lignites, it $1 \mathrm{~s} 2.7 \mathrm{ppm}$ (U.S. National Committee for Geochemistry, 1980).

Merritt (1985b) found a mean praseodymium content of $4 \mathrm{ppm}$ in ash samples of 31 Matanuska Valley coals. 


$$
\text { PROFILE } 52 \text { - RHENIUM }
$$

Symbol: $\operatorname{Re}$

Atomic number: 75

Atomic weight: 186.2

$\begin{array}{lcc} & \frac{C o a l}{\text { N.E. }} & \text { Ash } \\ \text { Alaska } & <0.2 \text { Ppm } & \text { N.E. } \\ \text { U.S. } & \text { N.E. } & \text { N.E. } \\ \text { World } & \text { N.E. }\end{array}$

Rhenium is a metallic element. Orheim (1979) reported the following clarke values for rhenlum: earth's crust, 0.0005 ppm; so1l, 0.005 ppm; and plant ash, $0.005 \mathrm{ppm}$. Sharkey and others (1975) found that rhentum content was <0.2 Ppm in 13 U.S. raw coals analyzed. Somerville and Elder (1977) found that rhenium content was below the 0.1 ppm detection limit in North Dakota lignite samples. There is no avallable data on thenlum concentrations in Alaska coals and coal ashes. 


\section{PROFILE 53 - RHODIUM}

Symbol: $\mathrm{Rh}$

Atomic number: 45

Atomic welght: 102.905

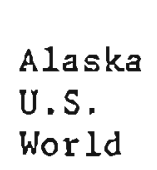

Coal

N.E.

Ash

Alaska

$<0.1$ ppm

$\overline{\mathrm{N} . \mathrm{E}}$.

N.E.

N.E.

N.E.

Rhodfum, a metallic element, has been reported to be below the detection l1mit of $0.1 \mathrm{ppm}$ in North Dakota lignites (Somerville and Elder, 1977). Sharkey and others (1975) found that rhodlum content was <0.1 ppm 1n 13 U.S. raw coals analyzed. There is no avallable data on rhodium content in Alaska coals. 


$$
\begin{aligned}
& \text { Alaska } \\
& \text { U.S. } \\
& \text { World }
\end{aligned}
$$

\author{
Coal \\ 0.3-150 рPा \\ N.E.
}

Ash

50-1,100 ppm

N.E.

Rubidium is an alkali element. Tureklan and Wedepohl (1961) reported the following average rubldiu concentrations in comon sedimentary rocks: shales, $140 \mathrm{ppm}$; sandstones, 60 ppm; and carbonates, 3 ppm. Orhelm (1979) reported the following clarke valueg for rubidium: earth's crust, 90 ppm; so11, $300 \mathrm{ppm}$; plant ash, 2 ppm; and water, $0.12 \mathrm{ppm}$.

Abernethy and G1bson (1963) found an average rubldium content of 15.5 ppm in coal. The U.S. National Comittee for Geochemistry (1980) reported an average worldwide concentration of $100 \mathrm{ppm}$ rubldium in coal.

Sharkey and others (1975) found that rubidium occurred in 100 percent of 13 U.S. raw coals analyzed, and that it ranged in concentration from 1 to 150 ppm. The U.S. National Committee for Geochemistry (1980) reported an average rubldium content in U.S. coals of 2.90 ppm. Gluskoter and others (1977) reported a geometric mean rubidium content of 19 ppm in 14 Appalachian region whole-coal samples, $17 \mathrm{ppm}$ in 56 Illinols basin whole-coal samples, and $2.4 \mathrm{ppm}$ in 29 Western U.S. whole-cosl samples. Los Alamos Sclentific Laboratory (1976) cited a rubld1um range in concentration of <91 to $1,100 \mathrm{ppm}$ in ashes of U.S. coals.

Merritt (1985b) reported a mean rubidtum content of 19 ppm in ash samples of 31 Matanuska Valley coals. 


\section{PROFILE 55 - RUTHENIUM}

Symbol: Ru

Atomic number: 44

Atomic weight: 101.07

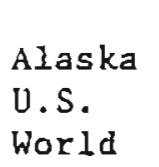
Coal
N.E.
$<0.1$ ppm
N.E.

Ash

N.E.

N.E.

Ruthenlum, a metalif element found in platlnum ores, was reported to be below the detection 11mit of $0.1 \mathrm{ppm}$ in North Dakota lignites (Somerville and Elder, 1977). Sharkey and others (1975) found that ruthenium content was $<0.1 \mathrm{ppm}$ in 13 U.S. raw coals analyzed. There is no available data on ruthentum concentrations in Alaska coals. 
PROFILE 56 - SAMARIUM

Symbol: Sm

Atomic number: 62

Atomic weight: 150.35

$\begin{array}{lll} & \frac{\text { Coal }}{\text { N.E. }} & \text { Ash } \\ \text { Alaska } & 0.2-10 \mathrm{ppm} & \text { N.E. } \\ \text { U.S. } & 0-10 \mathrm{ppm} & \text { N.E. } \\ \text { World } & & \end{array}$

Samarium is a metallic rare-earth element asaociated with silfcate minera1s. Tureklan and Wedepohl (1961) reported the following average samarlum concentrations in sedimentary rocks: shales, $6.4 \mathrm{ppm}$; sandstones, $10 \mathrm{ppm}$; and carbonates, $1.3 \mathrm{ppm}$.

Abemethy and Gibson (1963) Eound an average samarium content of 1.0 ppm in coal. The U.S. National Committee for Geochemistry (1980) reported an average worldwide concentration of 1.6 ppm samarium in coal.

Sharkey and ochers (1975) Eound that samartum occurred in 100 percent of 13 U.S. raw coals analyzed, and that it ranged in concentration from 1 to $6 \mathrm{ppm}$. Elsewhere, $1 \mathrm{t}$ has been reported that U.S. coals contain an average samartura content of $0.42 \mathrm{ppm}$; furthermore, a typical U.S. subbltuminous coal contains $0.50 \mathrm{ppm}$ samartum, and a typical U.S. 11gnite contalas 0.27 ppm samarium (U.S. National Commictee for Geochemistry, 1980). Gluskoter and others (1977) reported a geometric mean samarfum content of $2.4 \mathrm{ppm}$ in 14 Appalachtan region whole-coal samples, l.l ppm samarlum in 56 Illinois basin whole-coal samples, and $0.56 \mathrm{ppm}$ samarium in 21 Western U.S. whole-coal samples.

Merritt ( $1985 \mathrm{~b})$ reported a mean samarium concentration of $4.8 \mathrm{ppm}$ in ash samples of 28 Matanuska Valley coals. 


$\begin{array}{ll} & 0 . \frac{\text { Coal }}{3-20} \mathrm{ppm} \\ \text { Alaska } & 0-100 \mathrm{ppm} \\ \text { U.S. } & 0-100 \mathrm{ppm} \\ \text { World } & \end{array}$

$$
\begin{aligned}
& 20-\frac{\text { Ash }}{200} \text { PP⿴ } \\
& 2-160 \text { PP⿴ } \\
& \text { N. E. }
\end{aligned}
$$

Scandium is a metallic element found in various rare minerals, espectally silicates. It can be separated as a by-product during the processing of uranium ores. Turekian and Wedepohl (196l) reported the following average scandlum concentrations in common sedimentary rocks: shales, $13 \mathrm{ppm}$; sandstones, $1 \mathrm{ppm}$; and carbonates, $1 \mathrm{ppm}$. Scandium generally occurs in coal in appreciably greater concentration than its estimated average concentration in the earth's crust (Averitt, 1975).

\section{World Coals}

Abernethy and G1bson (1963) cited an average scandiun concentration in coal of 2.2 ppm. The U.S. National Comnittee for Geochemistry (1980) reported a worldwide average scandium content in coal of $5 \mathrm{ppm}$.

\section{United States Coals}

Sharkey and others (1975) found that scandlum occurred in 100 percent of 13 U.S. raw coals analyzed, and that it ranged in concentration from 3 to $30 \mathrm{ppm}$. Others have clted a range in scandlum content in U.S. coals from $<10$ to $100 \mathrm{ppm}$ (Los Alamos Sclentiflc Laboratory, 1976). Swanson and others (1976) reported an average scandlum content of $3.1 \mathrm{ppm}$ in $601 \mathrm{U} . \mathrm{S}$. coals. The U.S. National Committee for Geochemistry (1980) c1ted an average scandium content in U.S. coals of 3 ppr.

Scandium ranges in content in ashes of U.S. coals from 2 to $155 \mathrm{ppm}$, and shows average contents by rank as follows: anthracites, 61 pom; low-volactle bltuminous coals, 50 ppm; medium-volatile bltuminous coals, 56 ppm; high-volatile bituminous coals, $32 \mathrm{ppm}$; and subbltuminous coals and lignites, 18 ppm (Los Alamos Scientific Laboratory, 1976).

Appalachlan region. Swanson and others (1976) reported a geometric mean scandlum concent of $3 \mathrm{ppm}$ in 331 Appalachian region whole-coal samples. Gluskoter and others (1977) clted a geometric mean scandium content of 4.5 ppo in 14 Appalachian region coals.

Interior region. Swanson and others (1976) reported a geomerric mean scandium content of $3 \mathrm{ppm}$ in 194 Interlor region whole-coal samples. Gluskoter and others (1977) cited a geometrlc mean scandium content of $2.5 \mathrm{ppm}$ in 56 Illinols basin coals.

Western region. Swanson and others (1976) reported a geometric mean scandium content of 1.5 ppm in 93 Western region whole-coal samples and 5 ppm in 34 Texas coals. Giuskoter and others (1977) cited a geometric mean scandium content of $1.5 \mathrm{ppm}$ in 22 Western U.S. coals. 
Compared to other U.S. coals, the content of scandium is htgher in
Alaskan coals.

Northern Alaska province. Conwell and Triplehorn (1976) found a scandium content of 200 ppm in a Kukpuk River coal-ash sample and 30 ppm in a Cape Thompson coal-ash sample. Affolter and others (1981) reported a range of 0.3 to $20 \mathrm{ppm}$ scandium and a geometric mean scandium content of 2 ppm in 54 Utukok River Quadrangle whole-coal samples.

Cook Inlet-Susitna province. Merritt (3985b) cited a mean scandium content of $23 \mathrm{ppm}$ in 31 Matanusks Valley cosl-ash samples. Affolter and others (1981) reported a range of 1 to 7 ppm scandlum and a geometrlc mean of 3 ppm scandium in 10 Kenai quadrangle whole-coal samples. Additional1y, they found a range of 1 to 15 ppm scandium and a geometric mean of 3 ppm scandium in 34 Seldovia Quadrangle whole-coal samples.

Conwell (1977) reported a range in scandium concentration of 30 to 50 ppm and a mean scandfum content of $38 \mathrm{ppm}$ in seven Beluga fleld coal-ash samples. Based on samples of $s 1 x$ coal beds from the Tyonek Formation, Beluga field, Affolter and Stricker (1984) found that the concentration of scandium varied directly with the agh content of the coals.

Nenana province. Affolter and others (1981) reported a range of 1.5 to $10 \mathrm{ppm}$ scandium and a geometric mean of 3 ppm scandium in 20 Healy Quadrangle whole-coal samples. Affolter and Stricker (1987) found an average scandium content of $2.2 \mathrm{ppm}$ in two whole-coal samples of Seam No. 3, Usibe111 Mine. Merritt (1985a) cited a general factor of enrichment of $1.2 \mathrm{X}$ for scandium based on 1 ts abundance in Nenana basin coal-ash samples.

Alaske Peninsula province. Conwell and Triplehorn (1978) reported an average scandfum concentration of 26 ppm in eight Alaska Peninsula coal-ash samples. 
PROFILE 58 - SELENIUM

Symbol: $\mathrm{Se}$

Atomic number: 34

Atomic weight: 78.96

$\begin{array}{lcc} & \frac{\text { Coal }}{5-11} \text { ppm } & \frac{\text { Ash }}{\text { N.E. }} \\ \text { Ulaska } & 0 . S . & \text { N.E. } \\ \text { World } & 0.1-150 \text { ppm } & \text { N.E. }\end{array}$

Selenfun is a nonmetallic element resembling sulfur in character and assoclated with the sulfide group of minerals. It is obtalned primarily as a by-product of electrolytic copper refining. Turekian and Wedepoh1 (1961) reported the following average selentum concentrations in comon sedimentary rocks: shales, $0.6 \mathrm{ppm}$; sandstones, $0.05 \mathrm{ppm}$; and carbonates, $0.08 \mathrm{ppm}$. Orheim (1979) cited these clarke values for selen1um: earth's crust, $0.05 \mathrm{ppm}$; so11, $0.5 \mathrm{ppm;}$ plant ash, $1.0 \mathrm{ppm;}$ and water, $0.004 \mathrm{ppm}$.

Selentum generally occurs in coal in appreclably greater concentration than 1ts estimated average concentration in the earth's crust or 1 ts clarke value (Averitt, 1975; Gluskoter and others, 1977). It showa a very marked enrlchment factor of $82 \mathrm{X}$ in coal (U.S. Natlonal Comletee for Geochemistry, 1980).

Selenium is assoclated with both organtc and inorganic matter, but is more closely allied with inorganic fractions (Ruch and others, 1974). It is one of the elements of environmencal concern in cosl, and can be eariched on the surfaces of fly-ash particles from coal-flred plants (Mraw and others, 1983). Selenfum 1s presumed to be retained in high-temperature ash, and over 95 percent is retained in low-temperature ash (Ruch and others, 1974).

Abernethy and Gibson (1963) cited a general average selentum concentration in coal of $2.2 \mathrm{ppm}$.

\section{United States Coals}

Sharkey and others (1975) found that selentum occurred in 100 percent of 13 U.S. raw cosls analyzed, and that 1 t ranged in concentration from 0.04 to $0.3 \mathrm{ppm}$. Others have cited a range of 0.4 to $8 \mathrm{ppm}$ selentum for U.S. coals (Los Alamos Scientific Laboratory, 1976; Wewerka and others, 1976). Swanson and others (1976) found an average selenium concentration of 3.1 ppm in 601 U.S. whole-coal samples.

Appalachian region. Swanson and others (1976) reported a geometric mean selenfum contear of 3.5 ppm in 331 Eastern U.S. whole-coal samples. Gluskoter and others (1977) cited a geometric mean of $3.4 \mathrm{ppm}$ selenium in 23 Appalachian coals.

Interior region. Swanson and others (1976) reported a geometric mean selenium content of $2.8 \mathrm{ppm}$ in 194 Intertor regton whole-coal samples. Gluskoter and others (1977) cited a geometric mean of 2.0 ppm selenium in 113 Illinois basin coals. 
Western region. Swanson and others (1976) reported a geometric mean selenium content of $0.5 \mathrm{ppm}$ in 93 Western U.S. whole-coal samples and $5.8 \mathrm{ppm}$ In 34 Texas coals. Gluskoter and others (1977) cited a geometric mean of 1 to 3 ppm selentum in 29 Western U.S. coals.

Alaska Coals coals.

Compared to other U.S. coals, the content of selenium is low in Alaska

Northern Alaska province. Conwell and Triplehorn (1978) reported a selenium content of $1.4 \mathrm{ppm}$ in a Kukpuk River coal-ash sample and $1.8 \mathrm{ppm}$ in a Cape Thompson coal-ash sample. Affolter and others (1981) clted a range in selenium concentration of 0.1 to $1.2 \mathrm{ppm}$ and a geometric mean of $0.3 \mathrm{ppm}$ in 54 Utukok River Quadrangle whole-coal samples.

Cook Inlet-Susitna province. Mexritt (1985b) found a mean of 4 ppm selentum in 23 Matanuska Valley coal-ash samples. Affolter and others (1981) reported a range in selenium content of $<0.1$ to $0.3 \mathrm{ppm}$ and a geometric mean of 0.1 ppw in 10 Kenal Quadrangle whole-coal samples. In addition, they reported a range of 0.1 to 2 . I ppm selendum and a geometric mean of $0.4 \mathrm{ppm}$ selenium in 34 Seldovia Quadrangle coals. Conwell (1977) found a range of $<0.1$ to $0.4 \mathrm{ppm}$ selentum and a mean of $<0.2 \mathrm{ppm}$ selenium in seven Beluga fleid raw coal samples.

Nenana province. Affolter and others (1981) reported a range of 0.3 to 11 ppm selentum and a geomecric mean of 8 ppm selentum in 20 Healy Quadrangle whole-coal samples. Affolter and Strlcker (1987) found an average selentum content of $0.8 \mathrm{ppm}$ in two whole-coal samples of Seam No. 3, Ustbell1 Mine.

Alaska Peninsula province. Conwe11 and Triplehorn (1978) reported an average selentum concentration of 0.6 ppm in elght Alaska Pentnsula raw coal samples. 


$$
\text { PROFILE } 59 \text { - SILICON }
$$

Symbol: Si

Atomic number: 14

Atomic weight: 28.086

\begin{tabular}{|c|c|c|}
\hline A laska & $500-11 \frac{\operatorname{Cos} 1}{0,000} \mathrm{ppm}$ & $\frac{\text { Ash }}{N \cdot E}$ \\
\hline $\begin{array}{l}\text { U.S. } \\
\text { Worid }\end{array}$ & $\begin{array}{l}3,500-70,000 \mathrm{ppm} \\
0-100,000 \mathrm{ppm}\end{array}$ & $\begin{array}{c}90,000-300,000 \mathrm{ppm} \\
\text { N.E. }\end{array}$ \\
\hline
\end{tabular}

Silicon is a nonmetalitc element that occurs extensively in the earth's crust and contained mainly in silicate and aluminosilicate minerals. Stlicon dioxide $\left(\mathrm{SlO}_{2}\right)$ or quartz is one of the main constituents of coal ash, and silicon ls one of the major inorganic elements in coal. It has an 1mportant effect on the use of coal in combustion and cokemaking. Turekian and Wedepohl (1961) reported the following average silicon concentrations in common sedimentary rocks: shales, 73,000 ppm; sandstones, 368,000 ppm; and carbonates, 24,000 ppm.

\section{World Coals}

Abernethy and Gibson (1963) cited an average silicon concentration in coal of 23,100 ppm. The U.S. National Comittee for Geochemistry (1980) reported a worldwide average silicon content in coal of 2.8 percent.

\section{Unted States Coals}

Sharkey and others (1975) found that silicon occurred in 100 percent of 13 U.S. raw cosls analyzed, and that it ranged in concentration from 5,000 to $41,000 \mathrm{ppm}$. Others have cited a range in silicon content from 0.58 to 6.09 percent (Los Alamos Scientific Laboratory, 1976; Wewerka and others, 1976). Swanson and others (1976) reported an average U.S. s111con concentratron in 601 U.S. coals of 2.0 percent. The U.S. National Commitree for Geochemistry (1980) listed an average silicon content in U.S. coals of 2.6 percent. Silicon has been found to range in content from 9.3 to 28 percent in the ashes of U.S. coals.

Appalachlan regton. Swanson and others (1976) reported a geometric mean stlicon concentration of 1.2 percent in 331 Eastern U.S. whole-coal samples. Gluskoter and others (1977) cited a geometric mean silicon content of 2.6 percent in 23 Appalachian region coals.

Intertor region. Swanson and others (1976) reported a geomecric mean silicon content of 1.4 percent in 194 Interfor region whole-coal samples. Gluskocer and others (1977) c1ted a geometric mean silicon content of 2.3 percent in 113 Illinois basin coals.

Western regloa. Swanson and others (1976) reported a geometric mean silicon content of 1.1 percent in 93 Western reglon coals and 4.2 percent in 34 Texas coals. Giuskoter and others (1977) clted a geometric mean silicon content of 1.3 percent in 29 Western U.S. Coals. 


\section{Alaska Coals}

Affolter and others ( 1981$)$ reported geometric mean sillicon concentratlons of 1.8 percent, 2.4 percent, 2.1 percent, and 0.93 percent in wholecoal samples of the Healy (20), Kenai (10), Seldovla (34), and Utukok River (54) Quadrangles, respectlvely. Compared to the silicon content in 410 Powder River regton cal samples, the silicon content of the Healy, Kerai, and Seldovia subbituminous coals is slgniflcantly higher. Compared to the slilcon content of 295 Rocky Mountaln province coal samples, the silicon content of the Utukok River Quadrangle bituminous coals is significantly lower. Based on samples of $s i x$ coal beds from the Tyonek Formation, Beluga fleld, Affolter and Stricker (1984) found that the concentration of silicon varied directly with the ash content of the coals. 
PROFILE 60 - SILVER

Symbol: $\mathrm{Ag}$
Aromic number: 47

$$
\begin{aligned}
& \frac{\text { Coal }}{0.05-0.5 \mathrm{ppm}} \\
& <0.01-3 \mathrm{ppm} \\
& \text { N.E. }
\end{aligned}
$$

Atomic welght: 107.870

$$
\begin{aligned}
& 1-3 \frac{\text { Pp⿴ }}{\text { Ash }} \\
& <1-90 \text { ppd }
\end{aligned}
$$

N.E.

S1lver is a metalifc element with the highest thermal and electrical conductivity of the metals. It occurs uncomblned and in ores such as argentite $\left(\mathrm{Ag}_{2} \mathrm{~S}\right)$, and may also occur as a component of the mineral galena in coal. Turektan and Wedepohl (1961) reported the following average silver concentrations in common sedimentary rocks: shales, $0.07 \mathrm{ppm}$; sandstones, $0.0 X$ Ppm; and carbonates, 0.0X ppm. Orheim (1979) c1ted these clarke values for sllver: earth's crust, $0.07 \mathrm{ppm}$; soll, $1.0 \mathrm{ppm}$; plant ash, $1 \mathrm{ppm}$; and water, $0.0003 \mathrm{ppm}$.

\section{World Coals}

Silver generally occurs in coal in appreciably greater concentration than its estimated average concentration in the earth's crust (Averitt, 1975). The U.S. National Comittee for Geochemistry (1980) c1ted a worldwide average silver content in coal of $0.50 \mathrm{ppm}$. Berkowitz (1979) c1ted maximum silver concentrations in coal ash of $10 \mathrm{gm} / \mathrm{ton}$, and an average concentration of $2 \mathrm{gm} /$ ton.

\section{United States Coals}

Sharkey and others (1975) found that silver occurred in 92 percent of 13 U.S. raw coals analyzed, and that 1 r ranged in concentration from $<0.01$ co 3 ppm. The U.S. National Committee for Geochemistry (1980) c1ted an average U.S. silver content in coal of $0.20 \mathrm{ppm}$.

Gluskoter and others (1977) reported the following geometric mean silver concentrations in U.S. whole-coal samples by region: Appalachian region (13), $0.02 \mathrm{ppm}$, Illinois basin (37), $0.03 \mathrm{ppm}$, and Western U.S. (22), 0.02 ppm. Stlver exhibits a range in the ashes of U.S. coals of < 1 to $84 \mathrm{ppm}$, and has a mean value <l ppm in all ranks of coal (Los Alamos Sclentiflc Laboratory, 1976).

\section{Alaska Coals}

There exists abundant data concerning sllver concentrations in Aleska coals and coal ashes.

Northern Alaska province. Conwell and Trlplehorn (1976) analyzed two coal-ash samples from Rukpuk River and Cape Thompson, Northern Alaska for silver concentratton, but $1 t$ was undetected in both of the samples. Rao (1980) found a range of $<l$ to $7.8 \mathrm{ppm}$ silver and a mean of $<1.4$ ppm silver in 38 Cape Beaufort region raw coal samples. In addition, he reported a range 
of $<2$ to 17 ppm sliver and a mean of $<4$ ppm sllver In ash samples of the same coals. Rao (1980) stated that the concentration of silver was <2 ppm in the majortty of the Cape Beaufort region coal ashes. Rao and Wolfe (1981) analyzed subbltuminous B-ranked coals from Walnwright and Meade River areas, Northern Alaska and a high-volatile bituminous coal from Sagwon Bluffs and found no detectable silver in any of the samples.

Cook Inlet-Susitna province. Rao and Wolff (1981) reported that silver was not detected in high-volatile bituminous coals from the Castle Mountain and Premler Mlnes, Matanuska Valley. Merritt (1985b) found silver to be present in only one of 31 samples analyzed from ash samples of Matanuska Valley coals; it contalned $0.6 \mathrm{ppm}$ silver. Rao and Wolff (198I) did not find detectable stlver in elther raw coal or coal ash samples of the subbituminous C-ranked Cabin bed, Kenal fleld. Additionally, they reported that silver was not detected $1 \mathrm{n}$ coal and ash samples of the subbltuminous $C$ Waterfall bed, Beluga fleld, but did occur in the Sunflower Creek ligntte seam from the Yentna fleld. A raw coal sample of the lignite bed contalned 0.06 ppr silver and a coal-ash sample contalned 1.4 ppm stlver. A Broad Pass fleld lignite from Coal Creek also did not show detectable sliver in raw-coal and coal-ash samples (Rao and WolfE, 1981).

Nenana province, Silver was not detected in raw coals or coal ashes of Four Nenana basin subbituminous $C$ seams--No. 2, No. 4, No. 6 (Including three splits, top, middle, and lower), and Moose seams (Rao and Wolff, 1981). However, the Caribou Segm showed 1.3 ppm silver in coal ashes and $0.16 \mathrm{ppm}$ in the raw coal. Affolter and others (1981) reported a range of 0.07 to $0.3 \mathrm{ppm}$ silver and a geometric mean of 0.06 ppm silver in 20 Healy Quadrangle wholecoal samples. Two whole-coal samples of Seam No. 3, Ualbelli Mine, showed a s1lver content of $0.036 \mathrm{ppm}$ (Affolter and Stricker, 1987). Merr1tt (1985a) noted a general factor of enrichment of $13 \mathrm{X}$ for sliver based on $1 \mathrm{ts}$ abundance in Nenana basin coa1-ash samples.

A subbituminous C seam from Ober Creek, Jarvis Creek fleld showed 1.5 ppm stlver in coal ashes and $0.17 \mathrm{ppm}$ silver in a raw-coal sample. The subbituminous $C$ main seam at Little Tonzona River, western Nenana province, showed 2.9 ppm silver in a coal-ash sample and $0.40 \mathrm{ppm}$ in a raw-coal sample (R8o and Wolff, 1981).

Yukon-Koyukuk province. S1lver was not detected in coal-ash or raw-coal samples of the high-volatile bituminous ma1n seam from the Tramway Bar field, upper Koyukuk basin. 
PROFILE 61 - SODIUM

Symbol: $\mathrm{Na}$
Atomic number: 11

$$
\begin{aligned}
& <10 \frac{\operatorname{Cog} 1}{10-7,000} \mathrm{ppm} \\
& 100-6,000 \mathrm{ppm} \\
& 0-10,000 \mathrm{ppm}
\end{aligned}
$$

Atomic weight: 22.9898

$$
\begin{gathered}
\frac{\text { Ash }}{\text { N.E. }} \\
5,000-30,000 \text { Ppw } \\
\text { N.E. }
\end{gathered}
$$

Sodium is a metallic element that is naturally abundant in combined forms, especially as common salt. It is contalued malnly in silicate and aluminosilicate minerals. Turekian and Wedepohl (196I) reported che following sodium concentrations in common sedimentary rocks: shales, $9,600 \mathrm{ppm}$; sandstones, 3,300 ppm; and carbonates, $400 \mathrm{ppm}$.

Sodium is one of the major inorganic elements in the mineral constituents of coal. Sodium oxide is one of the important constituents of coal ash. Sodtum has an important effect on the use of coal in combustion and cokemaking.

\section{World Coals}

Abernethy and Gibson (1963) clted a general sodiun concentration in coal of 696 ppm. The U.S. National Committee for Geochemistry (1980) reported a worldwide average sodium concentration in coal of 0.02 percent.

\section{Unxted States Coals}

Sharkey and others (1975) found that sodluw occurred in 100 percent of 13 U.S. raw coals analyzed, and that it ranged in concentration from 100 to 1,000 ppm. Others have cited a range in sodfuw content in U.S. coals from 0 to 0.20 percent (Los Alamos Scientific Laboratory, 1976; Wewerka and others, 1976). Swanson and others (1976) found an average sodium concentration of 0.04 percent in 601 U.S. coals. The U.S. Natlonal Committee for Geochemistry (1980) reporced an average sodium content in U.S. coals of 0.06 percent. Sodium content ranges from 0.71 to 2.72 percent in the ashes of U.S. coals (Los Alamos Scientiflc Laboratory, 1976).

Appalachian region. Swanson and others (1976) reported a geometric mean sodiut concentration of 0.025 percent in 331 Eastern U.S. whole-coal samples. Gluskoter and others (1977) clted a geometric mean sodium content of 0.03 percent in 23 Appalachian coals.

Intertor region. Swanson and others (1976) reported a geometrlc mean sodium concentration of 0.026 percent in 194 Interior region whole-coal samples. Gluskoter and others (1977) clted a geometric mean sodium content of 0.03 percent in 113 Illinols basia coals.

Western region. Swanson and otherg (1976) reported a geometric mean sodium concentration of 0.1 percent in 93 Western region whole-coal samples and 0.009 percent in 34 Texas coals. Gluskoter and others (1977) cited a geometric mean sodium content of 0.06 percent in 29 Western U.S. coals. 


\section{Alaska Coals}

Conwell and Triplehorn (1976) clted a sodium content of 500 ppm in an ash sample from a Kukpuk Rlver, Northern Alaska coal. Affolter and others (1981) reported geometric mean sodfum concentrations of 0.012 percent, 0.21 percent, 0.10 percent, and 0.087 percent in whole-coal samples of the Healy (20), Kenai (10), Seldovia (34), and Utukok River (34) Quadrangles, respectively. Coupared with 410 Powder River region coal samples, the Healy Quadrangle coals are significanty lower in sodium, and coals of the Renal and Seldovia Quadrangles are significantly higher in sodium. Compared to 295 Rocky Mounta1n province coals, the Utukok Rlver Quadrangle coals are significantly higher in sodium. 
PROFILE 62 - STRONTIUM

Symbol: Sr

Atomic number: 38

Atomic weight: 87.62

\begin{tabular}{|c|c|c|}
\hline & Coal & Ash \\
\hline Alaska & $<10 \overline{0-2,000 \mathrm{ppm}}$ & $<500 \overline{\mathrm{ppm}}$ \\
\hline U.S. & $0-1,000$ ppष & $<100-10,000 \mathrm{ppm}$ \\
\hline World & $0-2,000 \mathrm{ppm}$ & N.E. \\
\hline
\end{tabular}

Strontium is an easily oxidizable metallic element that is associated with the hydrous aluminum phosphaces of the goyazite group. Turekian and Wedepoh1 (1961) reported the following average strontlum concentrations in common sedimentary rocks: shales, $300 \mathrm{ppm;}$ sandotones, $20 \mathrm{ppm}$; and carbonates, 610 ppm. Orhelm (1979) cited these clarke values for strontium: earth's crust, $375 \mathrm{ppm}$; soil, $300 \mathrm{ppm}$; plant ash, $30 \mathrm{ppm}$; and water, $8 \mathrm{ppm}$.

Strontium occurs in coal in appreciably greater concentration than its estimated average concentration in the earth's crust (Averitt, 1961). It results chiefly from the remaining consituents of orlginal plant cells, but secondary amounts appear to result from enrichment by circulating groundwater (Averitt, 1961).

\section{World Coals}

Aberaethy and Gibson (1963) clted an average strontium content in coal of $23 \mathrm{ppm}$. The U.S. National Committee for Geochemistry (1980) reported a worldwide average strontium concentration of $500 \mathrm{ppm}$.

\section{United States Coa1s}

Sharkey and others (1975) found that strontium occurred in 100 percent of 13 U.S. raw coals analyzed, and that it ranged in concentration from 17 to 1,000 ppm. Swanson and others (1976) reported an average strontium content of 112.5 ppm in 601 U.S. coals. The U.S. National Commttee for Geochemistry (1980) noted an average strontium content in U.S. coals of $100 \mathrm{ppm}$.

Strontlum ranges from 0.009 to 0.96 percent in ashes of U.S. coals, and occurs in the following average concentrations by rank: anthractes, 177 ppm; low-volatile bituminous coals, 818 ppm; medium-volatile bituminous coals, 668 ppm; high-volatile bituminous coals, I, $987 \mathrm{ppm}$; and subbituminous coals and Ifgnites, 4;660 ppm (Los Alamos Scientific Laboratory, 1976).

Appalachian region. Swanson and others (1976) reported a geometric mean strontium content of 70 ppw in 331 Eastern U.S. whole-coal samples. Gluskoter and others (1977) clted a geometrlc mean strontium content of 100 ppm in 14 Appalachtan coals.

Intertor region. Swanson and others (1976) reported a geometric mean strontium content of $30 \mathrm{ppm}$ in 194 Interfor reglon whole-coal samples. Gluskoter and others (1977) cited a geometric mean strontlum content of $30 \mathrm{ppm}$ in 56 Illinois basin coals. 
Western region. Swanson and others (1976) reported a geometrlc wean strontium content of 100 ppm in 93 Western region whole-coal samples and $150 \mathrm{ppm}$ in 34 Texas coals. Gluskoter and others (1977) c1ted a geometric mean strontium content of $220 \mathrm{ppm}$ in 22 Western U.S. coals.

\section{Alaska Coals}

Northern Alaska province. Conwell and Triplehorn (1976) found a strontium content of $2,000 \mathrm{ppm}$ in a Kukpuk River coal-ash sample, and $200 \mathrm{ppm}$ in a Cape Thomoson coal-ash sample. Affolter and others (1981) reported a range in strontium content of 30 to $2,000 \mathrm{ppm}$ and a geometric mean of 150 ppm in 54 Utukok River quadrangle whole-coal samples.

Cook Inlet-Susitna province. Merrltt (1985b) cited a mean strontium concentration of 199 ppm in 29 Matanuska Valley coal-ash samples. Affolter and others (1981) reported a range 1 s strontium content of 50 to 300 ppm and a geometric mean of 100 ppm strontium in 10 Kenal Quadrangle whole-coal samples. Additionally, they reported a range of 100 to 500 ppm strontum and a geometr1c mean of 200 ppu stroncium in 34 Seldovia Quadrangle whole-coal. samples. Merrite and others (1987) reported an average strontium content of 1,472 ppm in 31 coal-ash samples from the Kenal fleld.

Conwe11 (1977) listed a range of 700 to 1,500 ppm strontium and a geometric mean of 1,170 ppm strontium in seven Beluga fleld coal-ash samples. Rao and Smith (1987) anslyzed strontlum concentrations in coal-ash samples of flve seams from the Chuitra district, Beluga fleld. They reported average strontlum contents in multiple samples of the seams golng downsection, as follows: Blue Seam (15 samples), $2,850 \mathrm{ppm}$; Red 3 Seam (13 samples), 3,092 ppm; Red 2 Seam (26 samples), 1,756 ppm; Red 1 Seam (16 samples), 2,778 ppm; and Purple Seam (5 samples), 2,078 ppm.

Nenana province. Affolter and others (1981) reported a range in strontium content of 70 to 200 ppw and a geometric wean of $100 \mathrm{ppm}$ in 20 healy Quadrangle whole-coal samples. Affolter and Stricker (1987) found an average strontlum content of $295 \mathrm{ppm}$ in two whole-coal samples of Seam No. 3 , Usibelli Mine. Belowich (1987) cited an average strontium concentration of 120 PPI in 27 Jarvis Creek field whole-coal samples.

Alaska Peninsula province, Conwell and Triplehorn (1978) reported an average strontium concentration of $431 \mathrm{ppm}$ in elght Alaska Peninsula coal-ash samples.

Gulf of Alaska province. Smlth and Rao (1987) reported an average strontium concentration of $4,007 \mathrm{ppm}$ in 20 Bering River fleld coal-ash samples. 
PROFILE 63 - SULFUR

Symbol: $S$

Atomic number: 16

Atomic welght: 32.064

$\begin{array}{lll} & \text { Coal } & \text { Ash } \\ \text { Alaska } & 1,000 \frac{\text { C }}{-13,000 \mathrm{ppm}} & -- \\ \text { U.S. } & 3,000-55,000 \mathrm{ppm} & -- \\ \text { Worlo } & 3,000-60,000 \mathrm{ppm} & \end{array}$

Sulfur is a nonmetallic element that occurs widely in nature in both Eree and combined forms. It is most typically associated with the sulfide mineral group. Tureklan and Wedepohl (1961) reported the following average sulfur concentrations in common sedimentary rocks: shales, 2,400 PPF; sandstones, $240 \mathrm{ppm}$; and carbonates, 1,200 ppm.

Sulfur is one of the major elements in the mineral constituents of coal, and sulfur trioxide is one of the major constituents of coal ash. Sulfur forms a part of the ultimate coal analysis, and it is one of the elements of chlef environmental concern in coal. Sulfur has an important effect on the use of coal in combustion and cokemaking.

The average worldwide and U.S. sulfur content in coal is 2.0 percent (U.S. National Committee for Geochemistry, 1980). Sharkey and others (1975) Eound that sulfur occurred in 100 percent of 13 U.S. raw coals analyzed, and that it ranged in concentration from 700 to 10,000 ppm. Gluskoter and others (1977) reported a geometr1c mean sulfur content of 1.9 percent in 23 Appalachian region whole-coal samples, 3.4 percent in 113 I111nols basin whole-coal samples, and 0.70 percent in 29 Western U.S. whole-coal samples.

Alaskan coals are generally significantly lower in sulfur content than other U.S. coals (Merritt, 1987b). Affolter and Stricker (1984) found that those trace elements that normally show a positive correlation with sulfur in. most U.S. coals, such as $\mathrm{Fe}, \mathrm{As}, \mathrm{Cd}, \mathrm{Co}, \mathrm{Mo}, \mathrm{N} 1, \mathrm{~Pb}$, and $\mathrm{Zn}$ are low in concentration in coals of the Beluga field, southcentral Alaska. 


$$
\text { PROFILE } 64 \text { - TANTALUM }
$$

Symbol: Ta

Atom1c number: 73

Atomlc welght: 180.948

$\begin{array}{lcc} & \frac{C o a l}{N . E .} & \frac{\text { Ash }}{\text { N.E. }} \\ \text { Alaska } & <0.1-10 \text { Ppm } & \text { N.E. } \\ \text { W.S. } & \text { N.E. } & \text { N.E. }\end{array}$

Tantalum, a metallic element, has been found to have an average concentration ln coal of 0.11 ppm (Abernethy and Gibson, 1963). Sharkey and others (1975) found that tantalum occurred in 62 percent of 13 U.S. Iaw coals analyzed, and that it ranged in concentration from $<0.1$ to 8 ppm. Gluskoter and others (1977) reported a geometric mean tantalum content of $0.26 \mathrm{ppm}$ in 14 Appalachian regton whole-coal samples, 0.14 ppm tantalum in 56 Illinots bastn whole-coal samples, and 0.12 ppm tantalum in 22 Western U.S. whole-coal samples. Wewerka and others (1979) cited a range in tantalum concentration in ashes of Illinols basin coals of 0.3 to 1.0 ppu and a mean tantalum concentration of $0.7 \mathrm{ppm}$.

There is no avallable data on tantalum concentrations in Alaska coals. 


$$
\text { PROFILE } 65 \text { - TELLURIUM }
$$

Symbol: $\mathrm{Te}$

$\begin{array}{lcc} & \text { CoaI } & \text { Ash } \\ \text { Alaska } & \text { N.E. } & \text { N.E. } \\ \text { U.S. } & \text { O. I-0.5 Ppm } & \text { N.E. } \\ \text { World } & \text { N.E. } & \text { N.E. }\end{array}$

Tellurium is a metallic element that occurs naturally comblned with gold and other metals. It is a by-product of electrolytic refining of copper. Tellurtum generally occurs in coal in lower concentration than 1ts estroted average concentration in the earth's crust (Averitt, 1975).

Sharkey and others (1975) Eound that tellurlum occurred in 85 percent of 13 U.S. raw coals analyzed, and that it ranged in concentration from $<0.1$ to $0.4 \mathrm{ppm}$. The average U.S. tellurlum content in coal is $0.1 \mathrm{PPm}$ (U.S. National Commltee for Geochemistry, 1980). Somerville and E1der (1977) cited an average tellurfum concentration in North Dakota lignites of $0.27 \mathrm{ppm}$.

Conwell and Triplehorn (1976) found tellurium content in two Northern Alaska coals from Kukpuk Rlver and Cape Thompson to be below the detection imit. Merritt (1985b) reported a mean teliurium content of $1.7 \mathrm{ppu}$ in ash samples of 26 Matanuska Valley coals. 


$\begin{array}{lcr} & \frac{\text { Coal }}{N . E .} & <\frac{\text { Ash }}{\text { Ppm }} \\ \text { Alaska } & 0.04-3 \text { Ppm } & \text { N.E. } \\ \text { U.S. } & \text { N.E. } & \text { N.E. } \\ \text { Worid } & \text {. }\end{array}$

Terbium is a metallic rare-earth element. Tureklan and Wedepohl (1961) reported the following average terbium concentrations in common sedimentary rocks: shales, $1.0 \mathrm{ppm}$; sandstones, $1.6 \mathrm{ppm}$; and carbonates, $0.2 \mathrm{ppm}$.

The average worldwide terbium content in coal is 0.3 ppm (U.S. National Comittee for Geochemistry, 1980). Sharkey and others (1975) found that terblum occurred in 85 percent of $13 \mathrm{U} . \mathrm{S}$. raw coals analyzed, and that $1 t$ ranged in concentration from $<0.1$ to $2 \mathrm{ppm}$. The average U.S. terblum content in coal is $0.1 \mathrm{pPm}$; for U.S. subbituminous coals, it averages $0.1 \mathrm{ppm}$, and for U.S. 11gnites, it averages $0 . \mathrm{Lpm}$ (U.S. National Committee for Geochemistry, 1980).

Gluskoter and others (1977) reported a geometric mean terbium content of $0.28 \mathrm{ppm}$ in 14 Appalach1an region whole-coal samples, $0.18 \mathrm{ppm}$ terbium in 41 Illinois basin whole-coal samples, and $0.17 \mathrm{ppm}$ in 18 Western U.S. whole-coal samples.

Terblum concent was reported to be below the detection 11 int in all but one of 31 Matanuska Valley coal-ash samples analyzed; that sample contalned 0.4 ppm terblum (Merritt, 1985b). 


$\begin{array}{lcc} & \frac{\text { Coal }}{N . E .} & \text { Ash } \\ \text { Alaska } & <0.1-0.5 \mathrm{Ppm} & \text { N.E. } \\ \text { U.S. } & \text { N.E. } & <5 \text { PPm } \\ \text { World } & & \end{array}$

Thallium is a highly toxic metallic element. It generally occurs in coal in lower concentration than 1ts estimated average concentration in the earth's crust (Averitt, 1975). Thallium can be enriched on the surfaces of fly-ash particles from coal-fired plants (Mraw and others, 1983). Berkowltz (1979) reported a maximum concentration of thallium in coal ash of $5 \mathrm{gm} / \mathrm{ton}$. Tureklan and Wedepohl (1961) reported the following average thallium contents in common sedimentary rocks: shales, $1.4 \mathrm{ppm}$, sandstones, $0.82 \mathrm{ppm}$, and carbonates $0.0 \mathrm{Xpm}$.

Sharkey and others (1975) found that thallium occurred in 31 percent of 13 U.S. raw coals analyzed, and that it ranged in concentration from $<0.1$ to $0.3 \mathrm{ppm}$. The U.S. National Committee for Geochemistry (1980) cited an average U.S. thallium concentration in coal of 0.1 ppm. Gluskoter and others (1977) found a geometric mean thallium content of 0.59 ppm in 25 Illinois basin whole-coal samples. There is no avallable data on thallium concentrations in Alaska coals. 


\section{PROFILE 68 - THORIUM}

Symbol: Th

Atomic number: 90

Atomic welght: 232.038

Alaska
U.S.
World

$$
\begin{aligned}
& \frac{\operatorname{Coa} 1}{0.3-18} \mathrm{ppm} \\
& <0.1-10 \mathrm{ppm} \\
& 0-10 \mathrm{ppm}
\end{aligned}
$$

Ash
N.E.
N.E.
N.E.

Thortum is a metallic element with many lsotopes, but only Th 232 occurs oaturally. Thorium is found in association with various silicate minerals. Tureklan and Wedepohl (1961) reported the followlng average thorlum concentrations in common sedimentary rocks: shales, $12 \mathrm{ppm}$; sandstones, $1.7 \mathrm{ppm}$; and carbonates, 1.7 ppm. Abernethy and Gibson (1963) cited an average thorfum concentration in coal of 2.1 ppm.

\section{United States Coals}

Sharkey and others (1975) found that thorlum occurred in 92 percent of 13 U.S. raw coals analyzed and that it ranged in concentration from <0.1 to 5 pPI. Swanson and others (1976) found an average thorium content in 601 U.S. coals of $2.4 \mathrm{ppm}$. The U.S. National Comiltee for Geochenistry (1980) reported an average thortum concentration in U.S. coals of $1.9 \mathrm{ppm}$.

Appalachian region. Swanson and others (1976) reported a geometric mean thorlum content of $2.8 \mathrm{ppm}$ in 331 Appelachlan region whole-coal samples. Gluskoter and others (1977) cited a geometric mean thorlum content of 4.0 ppm in 14 Appalachian region coals.

Interfor reglon. Swanson and others (1976) reported a geometric mean thorfum content of 1.6 ppm in 194 Interlor region whole-coal samples. Gluskoter and others (1977) clted a geometric mean thorlum content of 1.9 ppm In 56 Illinols basin coals.

Western region. Swanson and others (1976) reported a geometric mean thorium content of $2.4 \mathrm{ppm}$ in 93 Western whole-coal samples and 3 ppm in 34 Texas coals. Gluskoter and others (1977) cited a geometric mean thorium content of 1.8 ppm in 22 Western U.S. coals.

\section{Alaska Coals}

Northern Alaska province. Conwell and Triplehorn (1976) found an average concentration of 4.8 ppm thorium in a Cape Thompson, Northern Alaska raw coal sample. Affolter and others (1981) reported a range in thortum content of 0.3 to $15 \mathrm{ppm}$ and a geometric mean of $1.6 \mathrm{ppm}$ in 54 Utukok River Quadrangle whole-coal samples.

Cook Inlet-Susitna province. Merritt (1985b) cited a mean thorium concentration of $8.8 \mathrm{ppm}$ in 26 Matanuska Valley coal-ash samples. Affolter and others (1981) reported $a$ range in thortum content of 1.9 to 6.9 ppm and a geometric mean of $2.2 \mathrm{ppm}$ thorium in 34 Seldovia Quadrangle whole-coal 
samples. Conwell (1977) found a range of $<3.0$ to 5.9 ppm thortum and a wean of <3.8 ppm in seven Beluga field raw coal samples. Based on samples of six coal beds from the Tyonek formation, Beluga fleld, Affolter and Stricker (1984) found that the concentration of thorium varled directly with the ash content of the coals.

Nenana province. Affolter and others (1981) reported a range in thorium content of 0.7 to 18 ppm and a geometric mean of 2.5 ppm in 20 Healy Quadrangle whole-coal samples. Affolter and Stricker (1987) cited an average thorlum content of $0.6 \mathrm{ppm}$ in two whole-coal samples of Seam No. 3, Usibell1 Mine.

Alaska Peninsula province. Conwel1 and Trlplehorn (1978) reported an average thorfum concentration of $<3.4 \mathrm{ppm}$ in elght Alaska Peninsula raw coal samples. 


$$
\text { PROEILE } 69 \text { - THULIUM }
$$

Symbo 1: Tm

Atomic number: 69

Atom1c we1ght: 168.934

$\begin{array}{lcc} & \frac{\text { Coal }}{\text { N.E. }} & \text { Ash } \\ \text { Alaska } & <0.1 \mathrm{ppm} & \text { N.E. } \\ \text { U.S. } & \text { N.E. } & \text { N.E. } \\ \text { World } & \text { N.E. }\end{array}$

Thulium is a rare-earth element with lsotope mass numbers ranging from 161 to 176. Turekian and Wedepohl (1961) reported the followlng average thulium contents in common sedimentary rocks: shales, 0.2 ppm; sandstones, $0.3 \mathrm{ppm} ;$ and carbonates, $0.04 \mathrm{ppm}$.

Sharkey and others (1975) found that thulium content was <0.1 ppm in 13 U.S. raw coals analyzed. The U.S. average thullum concentration in coal is $0.07 \mathrm{Ppm}$; far U.S. subbltuminous coals, it averages $0.07 \mathrm{pPm}$, and for U.S. lignices, $1 \mathrm{t}$ averages $0.07 \mathrm{ppm}$ (U.S. Nattonal Committee for Geochemistry, 1980).

There is no available data on thulium concentrations in Alaska coals. 


$$
\text { PROEILE } 70 \text { - TIN }
$$

Symbol: Sn Atomic number: 50

Atomic welght: 118.69

$\begin{array}{ll} & \frac{\operatorname{Coa} 1}{\text { Alaska }} \\ \text { U.S. } & 0.5-10 \mathrm{pPm} \\ \text { World } & <0.01-5 \mathrm{PPm} \\ & \text { N.E. }\end{array}$

$$
\begin{aligned}
& \text { Ash } \\
& 10-\frac{50 p m}{50} \mathrm{ppr} \\
& 0-5,000 \mathrm{ppm} \\
& \text { N.E. }
\end{aligned}
$$

Tin is a metalif element obtained chlefly from cassiterite $\left(\mathrm{SnO}_{2}\right)$. Tureklan and Wedepohl (1961) reported the following average tin concentrations la common sedimentary rocks: shales, $6.0 \mathrm{ppm;}$ sandstones, $0 . \mathrm{X}$ Ppm; and carbonaces, 0.X ppo. Orheim (1979) cited these clarke values for tin: earth's crust, $32 \mathrm{ppm}$; so1l, $10 \mathrm{ppm}$; plant ash, $1.0 \mathrm{ppm}$.

Tin generally occurs in coal in appreclably greater concentration than 1ts estimated average concentration in the earth's crust (Averitt, 1975). Tin is generally retained in high-temperature ash (Ruch and others, 1974). Berkowitz (1979) reported a maximum tin concentration in coal ash of $500 \mathrm{gm} / \mathrm{ton}$ and an average concentration of $200 \mathrm{gm} / \mathrm{ton}$.

\section{United States Coals}

Sharkey and others (1975) Eound that tin occurred in 100 percent of 13 U.S. raw coals analyzed, and that it ranged in concentration from 1 to $47 \mathrm{ppm}$. Valkovic (1983) reported a range $1 \mathrm{n}$ U.S. coals of 0 to $51 \mathrm{ppm} \mathrm{tin}$. The U.S. National Commlttee for Geochemistry (1980) c1ted a U.S. average concentration in coal of $1.6 \mathrm{ppm}$ tin. Tin has been found to range from 0 to 4,250 ppm in ashes of U.S. coals and shows the following average concentratlons by rank: anthracites, 962 ppm; low-volat1le bltuminous coals, 92 ppm; medium-volatile bituminous coals, 75 ppm; high-volatile bituminous coals, 171 ppm; subbituminous coals and lignites, 156 ppm (Los Alamos Sclentific Laboratory, 1976).

Appalachian region. Los Alamos Scientific Labaratory (1976) reported an average concentracion of $0.4 \mathrm{ppm} t$ in $1 \mathrm{p} 73$ Appalachian region whole-coal samples. Gluskoter and others (1977) cited a geometric mean of $0.97 \mathrm{ppm}$ in in 19 Appalachian coals.

Intertor region. Los Alamos Sclentiflc Laboratory (1976) reported an average concentration of $1.5 \mathrm{ppm} t 1 n$ in 53 Eastern Interior whole-coal samples. Gluskoter and others (1977) clted a geometric mean tin concentratyon of $0.94 \mathrm{ppm}$ in 60 Illinols basin coals.

Western region. Los Alamos Sclentific Laboratory (1976) reported an average concentration of $1.3 \mathrm{ppm} t \ln$ in 48 Wegtern and Southwestern Interlor region whole-coal samples and 0.9 ppm in 51 Northern Great Platns region coals. Gluskoter and others (1977) ctted a geometric mean tin concentration of $0.43 \mathrm{ppm}$ in 26 Western U.S. coals. 


\section{Alaske Coals}

Northern Alaska province. Rao (1980) reported that several Cape Beaufort region samples showed abnormally high concentrations of tin, but he made no invegtigation to determine the mode of occurrence of tin in these samples. In 38 raw coal samples, he found a range in tin content from 2.6 to $570 \mathrm{ppm}$ and a mern content $<40 \mathrm{ppm}$. In ash samples of the same coals, he cited a range in tin content of $<10$ to $4,600 \mathrm{ppm}$ and a mean of $<297 \mathrm{pPm}$.

Cook Inlet-Susitna province. Merritt (1985b) reported a mean tin content of 5 ppm in 29 Matanuska Valley coal-ash samples. Rao (1968) c1ted an average tin concentration of $0.8 \mathrm{ppm}$ in elght Kenal fleld raw coal samples and 8.4 ppm tin in ash samples of the same coals. Rao and Wolff (1981) analyzed tin contents in coal samples of upper and lower benches of a Sunflower Creek seam from the Yentna fleld. Average raw-coal tin content in this ilgnite was $1.6 \mathrm{ppm}$, and ash samples contalned an average tin content of 38 ppm. A Coal Creek, Broad Pass fleld, I1gnite contalned 5.3 ppm $t i n$ in a raw-coal sample and $27 \mathrm{ppm} t$ in in a coal-ash sample (Rao and Wolff, 1981).

Nenana province. Rao (1968) reported an average tin concentration of 2.4 ppm in 25 Nenana basin raw-coal samples and $29.6 \mathrm{ppm}$ in in ash samples of the same coals. Rao and Wolff (1981) found $5.4 \mathrm{ppm}$ tin in a raw-coal sample of the lower bench, No. 6 seam, Nenana basin. Ash of this subbituminous C-ranked coal contained $39 \mathrm{ppm}$ tia. An average tin concentration of 1.2 ppm has been reported for three raw-coal samples of the Jarv1s Creek field (Rao, 1968); ash samples of these coals contalned an average 12.3 ppw tin.

Yukon-Koyukuk province. Rao and Wolff (1981) reported tin concentrations in the high-volatile bituminous main seam from the Tramway Bar fleld. A raw-coal sample contained $9.9 \mathrm{ppm}$ tin and a coal-ash sample contalned 26 ppon tin. 


$\begin{array}{lll} & \frac{\text { Coal }}{-5,500 \mathrm{ppm}} & <10, \overline{\text { Ash }} \\ \text { Alaska } & 1000 \mathrm{ppm} \\ \text { U.S. } & <100-4,000 \mathrm{ppm} & 1,000-30,000 \mathrm{ppm} \\ \text { World } & <10,000 \mathrm{pPm} & \text { N.E. }\end{array}$

Titanium is a metallic element that occurs widely in igneous rocks. It is particularly assoctated with the minerals rut 1 le $\left(\mathrm{T} 1 \mathrm{O}_{2}\right.$ ) and anatase ( $\mathrm{T} 1 \mathrm{O}_{2}$ ) and also with various silicate minerals. Tureklan and Wedepoh1 (1961) reporced the following average citanfum concentrations in common sedimentary rocks: shales, 4,600 $\mathrm{ppm}$; sandstones, 1,500 $\mathrm{ppm}$; and carbonates, $400 \mathrm{ppm}$. Orhe1m (1979) c1ted these clarke values for titanium: earth's crust, 5,700 ppm; so11, 5,000 ppm; plant ash, $2 \mathrm{ppm} ;$ and water, $0.001 \mathrm{ppm}$.

Titanium is one of the major inorganic elements in the mineral constituents of coal. It generally occurs in cosl in lower concentration than its estimated average concentration in the earth's crust (Averitt, 1975). Titanium is assoclated with both organic and inorganic matter, but is more closely allied with organtc fractions (Ruch and others, 1974). It tends to be carried with the dissolved coal substance in solvent refining or similar solution techniques (Rao, 1976). Even a few ppm ticanium in carbon electrodes is detrimental to the production of aluminum by the electrolytic process since it causes brittleness in the flulshed metal (Stach and others, 1982).

\section{World Coals}

Abernethy and Gibson (1963) clted an average titanium concentration in coal of 506 ppm. The U.S. National Commttee Eor Geochemistry (1980) reported a worldwide average titanium content of 0.05 percent in coal.

\section{United States Coals}

Sharkey and others (1975) found that titanium occurred in 100 percent of 13 U.S. raw coals analyzed, and that 1t ranged in concentration from 200 to 1,800 ppm. Others have cited a range in titantum content in U.S. coals from 0.002 to 0.32 percent (Los Alamos Sclentific Laboratory, 1976; Wewerka and others, 1976). Swanson and others (1976) reported an average titanium content in $60 \mathrm{l}$ U.S. coals of 0.1 percent. The U.S. National Comittee for Geochemistry (1980) cited an average titantum content in U.S. coals of 0.08 percent. Titanium ranges in content from 0.1 to 2.6 percent in the ashes of U.S. coals (Los Alamos Sclentiflc Laboratory, 1976).

Appalachian region. Los Alamos Sclentiflc Laboratory (1976) listed an average titanium content of $350 \mathrm{ppD}$ in 73 Appalachian region whole-coal samples. Swanson and others (1976) reported a geometric mean ctuanium concentration of 0.074 percent in 331 Eastern U.S. coals. Gluskoter and others (1977) cited a geometric mean titanium content of 0.09 percent in 23 Appalachian coals. 
Interior region. Los Alamos Scientiflc Laboratory (1976) listed an average t1tanium content of $450 \mathrm{ppm}$ in 53 Eastern Interior reglon whole-coal samples. Swanson and others (1976) reported a geometric mean titanium concentration of 0.04 percent in 194 Incerior region coals. Gluskoter and others (1977) cited a geonetric mean titanium content of 0.06 percent in 113 Illinols basin coals.

Westera region. Los Alamos Scientific Laboratory (1976) 11sted an average titantum content of $250 \mathrm{pPm} 1 \mathrm{n} 48$ Western and Southwestern Interfor region whole-coal samples and $591 \mathrm{ppm}$ in 51 Northern Great Plains region whole-cosl samples. Swanson and others (1976) reported a geometric mean eltanium concentracion of 0.037 percent in 93 Western coals and 0.11 percent in 34 Texas coals. Gluskoter and others (1977) cited a geometric mean titantum content of 0.05 percent in 29 Western U.S. coals.

\section{Alaska Coals}

Northern Alaska, province. Rao (1968) reported an average titanium concentrat1on of $698 \mathrm{ppm}$ in 12 Northern Alaska raw-coal samples; ash samples of the same coals contained an average 5,334 ppm titanium.

Cook Inlet-Susitna province. Rao (1968) cited an average thtantum content of 1,045 ppa In 22 Matanuska Valley raw-coal samples and 6,509 ppm t1taniun in each samples of the same coals. In addition, he reported an average titanium concentration of $154 \mathrm{ppm}$ in elght Kenal fleld raw-coal samples and 1,473 ppm titanium in ash samples of the same coals.

Conwel1 (1977) reporred a range of 2,000 to 7,000 ppm titanium and a mean of 4,570 ppm titantum 1a seven Beluga fleld coal-ash samples. Based on samples of $\mathrm{B} 1 \mathrm{x}$ coal beds from the Tyonek Formation. Beluga fleld, Affolter and Stricker (1984) found that the concencration of titanium varted directly with the ash content of the coals.

Nenana province. Rao (1968) found an average titanium content of $341 \mathrm{ppm}$ in 25 Nenana basin raw-coal samples and 2,634 ppm in ash samples of the same coals. In addition, he reported an average titanium content of 177 ppw in three Jarvis Creek field raw-coal samples and 1,847 ppm titanium in ash samples of the same coals.

Gulf of Alaska province. Rao (1968) clted an average titanium content of 213 ppm in five Bering River fleld raw coal samples and 7,480 ppm titanium in ash samples of the same coals. 


$$
\text { RROFILE } 72 \text { - TUNGSTEN }
$$

Symbol: $W$

Atomic number: 74

Atomic welght: 183.85

$\begin{array}{lcc} & \frac{\text { Coal }}{\text { N.E. }} & \frac{A s h}{N . E} . \\ \text { Alaska } & <0.1-0.5 \mathrm{ppm} & <10-200 \mathrm{ppm} \\ \text { U.S. } & \text { N.E. } & \text { N.E. } \\ \text { World } & \end{array}$

Tungsten is an element with the highest melting point of all wetals. It is extracted from wolframite $\left[(\mathrm{Fe}, \mathrm{Mn}) \mathrm{WO}_{4}\right\}$, scheelite (CaWO ${ }_{4}$ ), and other minerals. Tureklan and Wedepohl (1961) reported the following average tungsten contents in comon sedimentary rocks: shales, $1.8 \mathrm{ppm}$; sandstones, $1.6 \mathrm{ppm}$; and carbonates, $0.6 \mathrm{ppm}$. Orheim (1979) c1ted these clarke values for tungsten: earth's crust, $1.5 \mathrm{ppm}$; soil, $1.0 \mathrm{ppm}$; plant ash, $0.5 \mathrm{ppm}$; and water, $0.00003 \mathrm{ppm}$. Tungsten generally occurs in coal in lower concentration than its estimated average concentration in the earth's crust (Averitt, 1975).

\section{United States Coals}

Sharkey and others (1975) found that tungsten occurred in 69 percent of 13 U.S. raw coals analyzed, and that it ranged in concentration from $<0.1$ to $0.4 \mathrm{ppm}$. Somerville and Elder (1977) cited an average tungsten concentration In 12 sampleg of North Dakota lignites of 0.58 ppm. Wewerka and others (1979) cited a range in tungsten concent from 0.5 to $1.2 \mathrm{ppm}$ in Illinois basin coals. The U.S. Netional Comittee for Geochemistry (1980) listed an average tungsten content in U.S. coals of $2.5 \mathrm{ppm}$. Gluskoter and others (1977) found the following geometrlc mean tungsten contents in U.S. wholecoal samples by reglon, as follows: Appalachian region (14 samples), $0.62 \mathrm{pPm}$; Illinois basin (56 samples), $0.63 \mathrm{ppm}$; and Western U.S. (22 samples), $0.58 \mathrm{ppm}$. Los Alamos Sclentific Laboratory (1976) reported a range in tungsten content of $<10$ to $182 \mathrm{ppm}$ in ashes of U.S. coals.

\section{Alaska Coals}

There existg very little data concerning tungsten concentrations in Alaska coals and coal ashes. Conwell and Trlplehorn (1976) did not find detectable tungsten in Kukpuk River and Cape Thompson, Northern Alaska coal-ash samples. Merritt (1985b) found that tungsten was present in only 2 of 31 samples of Matanuska Valley coal-ashes analyzed. In these two samples, tungsten concentrations were $<3 \mathrm{ppm}$. 
PROFILE 73 - URANIUM

Symbo1: U

Atamic number: 92

Atomic weight: 238.03

$\begin{array}{lcc} & \frac{\text { Coal }}{-7} & \text { Ash } \\ \text { Alaska } & 0.2-7 \mathrm{PPm} & \text { N.E. } \\ \text { U.S. } & <10-1,000 \mathrm{ppm} & \text { N.E. } \\ \text { World } & \text { N.E. } & \text { N.E. }\end{array}$

Uranium is a metallic element that is easily oxidizable. It is a radloactive element whth numerous 1sotopes, $\mathrm{U}_{23 \beta}$ belng the most abundant in nature. Vranium accurs in several minerals pncluding pltchbleade or uraninite $\left(\mathrm{UO}_{2}\right)$ and carnotite $\left.\left[\mathrm{K}_{2}\left(\mathrm{UO}_{2}\right)_{2}\left(\mathrm{VO}_{4}\right)_{2} \cdot \mathrm{nH}_{2} \mathrm{O}\right)\right]$. It may be assoclated with anomelously high contents of arsenic, germanium, selenium, cobalt, and zirconlum, and occurs as compounds or complexes intimately assoclated with the organtc constituents of coal (Averitt, 1961). It has been found that uranium has a strong chemlcal afflnity for carbonaceous material; it can be leached by groundwater from overlylng rocks and carrled downward to be precipitated on or in underlying carbonaceous rocks (Aver1tt, 1961). Uranium formed in part during the first stage in the coalification process (Stach and others, 1982).

Turekian and Wedepoh1 (1961) reported the following average uranlum concentrations in comon sedimentary rocks: shales, 3.7 ppm; sandstones, $0.45 \mathrm{ppm}$; and carbonates, $2.2 \mathrm{ppm}$. Orheim (1979) c1ted these clarke values for uranium: earth's crust, $2.7 \mathrm{ppm}$; soll, $1.0 \mathrm{ppm}$; plant ash, $0.6 \mathrm{ppw}$; and water, $0.003 \mathrm{ppm}$.

Uranlum ts one of the elements of chlef environmental concem in coal. It occurs in coal in vastly greater concentration than Its estimated average concentration in the earth's crust (Aver1tt, 1961). Unusual concentrations of uranfum occur in some coals and IIgnites of Texas and North Dakota, and wuch consideration and research has been devoted to recovering commerclal quantities of uranium from coal (Altschuler and Johnston, 1976; Stach and ochers, 1982).

\section{World Coals}

Abernethy and Gibson (1963) cited an average uranlum content in coal of $2.18 \mathrm{ppm}$. The U.S. National Comnlttee on Geochemistry (1980) reported a worldwlde average uranium concentration in coal of $1.0 \mathrm{ppm}$.

\section{Un1ted States Coals}

Sharkey and others (1975) found that uranlum occurred in 92 percent of 13 U.S. raw coals analyzed, and that 1 t ranged in concentration from $<0.1$ to I ppm. Others found that urantum content ranges in U.S. coals from $<10$ to 1,000 ppm (Los Alamos Scientiflc Laboratory, 1976). Swangon and others (1976) found an average uranium content in $601 \mathrm{U} . \mathrm{S}$. coals of $1.4 \mathrm{ppm}$. The U.S. National Committee for Geochemistry (1980) reported an average uranium concentracion in coal of $1.6 \mathrm{ppm}$. 
Appalachian region. Swanson and others (1976) clted a geometric mean uranium content of $1 \mathrm{ppm}$ in $33 \mathrm{l}$ Eastern U.S. whole-coal samples. Glugkoter and others (1977) listed a geometric mean uranlum content of 1.3 ppm in 14 Appalachian coals.

Intertor region. Swanson and ochers (1976) cited a geometric mean uranium content of $1.4 \mathrm{ppm}$ in 194 Interior region whole-coal samples. Gluskoter and others (1977) listed a geometric mean uranium content of 1.3 ppm In 56 Illinois basin coals.

Western region. Swanson and others (1976) cited a geometric mean uranium content of $0.7 \mathrm{ppm}$ in 93 Westerm coals and 2.4 ppm uranium in 34 Texas coa1s. Gluskoter and others (1977) 11sted a geometric mean uranium content of $0.99 \mathrm{ppm}$ in 22 Western U.S. coals.

\section{Alaska Coals}

Compared to other U.S. coals, the content of uranium in Alaskan coals ts similar.

Nortbern Alaska province. Conwell and Triplehorn (1976) found a high uranium concentration of 12.1 ppm in a Cape Thompson, Northern Alaska, raw-coal sample. Affolter and others (1981) clted a range in uranium content of 0.2 to 6.2 ppm in 54 Utukok River Quadrangle whole-coal samples and a geometric mean of $1.0 \mathrm{ppm}$.

Cook Inlet-Susttna province. Merritt (1985b) Eound a mean urantum content of 4 ppm in 30 Matanuska Valley coal-ash samples. Affolter and others (1981) reported a range in uranium content of $<0.5$ to 1.2 ppo and a geometric mean of 0.7 ppm in 10 Kenal Quadrangle whole-coal samples. Additionally, they reported a range in uranium content of 0.3 to 3.1 ppm and a geometric mean of 0.5 ppm uranium in 34 seldovia Quadrangle whole-coal samples. Conwe11 (1977) found a range in uranium content of $<0.2$ to 1.8 ppm and a mean of $<1.0$ pp⿴囗十 uranium in seven Beluga fleld raw-coal samples. Based on samples of six coal beds from the Tyonek Formation, Beluga field, Affolcer and Stricker (1984) found that the concentration of urantum varied directly with the ash content of the coals.

Nenana province. Affolter and others (1981) listed a range in uranium concencration of 0.4 to $5.2 \mathrm{ppm}$ and a geometric mean of $1.1 \mathrm{ppm}$ in 20 Healy Quadrangle whole-coal samples. Affolter and Stricker (1987) c1ted an average uranium content of $0.5 \mathrm{ppm}$ in two whole-coal samples of Seam No. 3, Ustbell1 Mine.

Alaska Peninsula province. Conwell and Triplehorn (1978) reported an average uranium content of 1.4 ppm in elght Alaska Peninsula whole-coal samples. 


\section{PROFILE 74 - VANADIUM}

Symbol: V

Acomic number: 23

Atomic weight: 50.942

$\begin{array}{ll} & \text { Coal } \\ \text { Alaska } & 2-200 \mathrm{pPm} \\ \text { U.S. } & 0-1,300 \mathrm{ppm} \\ \text { World } & \text { N.E. }\end{array}$

$$
\begin{aligned}
& \text { Ash } \\
& 100-600 \text { ppm } \\
& 5-50,000 \text { Ppm } \\
& 60-79,000 \text { PPm }
\end{aligned}
$$

Vanadium is a metallic element found in several minerals, especially vanadinite $\left(\mathrm{Pb}_{5} \mathrm{Cl}\left(\mathrm{VO}_{4}\right)_{3}\right]$ and carnotite $\left[\mathrm{R}_{2}\left(\mathrm{UO}_{2}\right)_{2}\left(\mathrm{VO}_{4}\right)_{2} \cdot \mathrm{nH}_{2} \mathrm{O}\right]$. It $1 \mathrm{~s}$ one of the elements assoclated with both organic and inorganic matter, but is more closely allied with organtc fractions (Ruch and others, 1974). It generally occurs in coal in appreclably greater concentration than 1 ts estimated average concentration in the earth's crust (Averftt, 1975). Even a few ppm of vanadium in carbon electrodes is hamful to the production of aluminum by the electrolytic process since it causes brittleness in the finished mecal (Stach and others, 1982). Over 95 percent of vanadium is retalned in lowremperature ash, and possibly up to 25 percent is retained in hightemperature ash (Ruch and others, 1974).

Turekian and wedepohl (1961) reported the following average vanadium concentrations in common sedimentary rocks; shales, $130 \mathrm{ppm}$; sandstones, $20 \mathrm{ppm}$; and carbonates, $20 \mathrm{ppm}$. Orthelo (1979) c1ted these clarke values for vanadium: earth's crust, 135 ppm; soll, 100 ppm; plant ash, 22 ppm; and water, $0.002 \mathrm{ppra}$.

\section{World Coals}

Abernethy and Gibson (1963) reported a general average vanadlum concentration in coal of $28.5 \mathrm{ppm}$. The U.S. National Comittee for Geochemistry (1980) cited a worldwide average vanadium content in coal of $25 \mathrm{ppm}$.

\section{United States Coals}

Sharkey and others (1975) Eound that vanadium occurred in 100 percent of 13 U.S. raw coals analyzed, and that it ranged in concentration from 2 to $77 \mathrm{ppm}$. Others have cited a range in vanadium content in U.S. coals of 0 to 1,281 ppm (Los Alamos Sclentif1c Laboratory, 1976). Swanson and others (1976) reported an average vanadium content 10601 U.S. coals of $19.2 \mathrm{ppm}$. The U.S. National Commttee for Geochemistry (1980) listed an average vanadium concentration in U.S. coals of $20 \mathrm{ppm}$. Vanadium ranges from 6 to $3,800 \mathrm{ppm}$ in ashes of U.S. coals, and showg the following average concentrations by rank: anthracites, 248 ppm; 10w-volatile bituminous coals, 278 ppm; medium-volatile bituminous coals, 390 ppo; high-volatile bituminous coals, $249 \mathrm{ppm}$; and subbituminous coals and lignites, $125 \mathrm{ppm}$ (Los Alamos Scientific Laboratory, [976).

Appalachían region. Los Alamos Sclentific Laboratory (1976) reported an average vanadium concentration of 21 ppm in 73 Appalachian region whole-coal samples. Swanson and others (1976) c1ted a geometric mean vanadum content 
of 20 ppm in 331 Eastern U.S. coals. Gluskoter and others (1977) listed a geometric mean vanadium content of $35 \mathrm{ppm}$ in 23 Appalachian coals.

Interior region. Los Alamos Scientific Laboratory (1976) reported an average vanadium concentration of 35 ppw 1 n 53 Eastern Interior region whole-coal samples. Swanson and others (1976) cited a geometric mean vanadium content of $20 \mathrm{ppm}$ in 194 Interfor region coals. Gluskoter and others (1977) listed a geometric mean vanadium content of $29 \mathrm{ppm}$ in 113 Illinols basin coals.

Western region. Los Alamos Scientiflc Laboratory (1976) reported an average vanadlum concentration of $18 \mathrm{ppm}$ in 48 Western and Southwestern Intertor region whole-coal samples and $16 \mathrm{ppm}$ in 51 Northern Great Plalns regton whole-coal samples. Swanson and others (1976) cited a geometric mean vanadium content of 7 ppm in 93 Western region coals and 30 ppo in 34 Texas coals. Gluskoter and others (1977) listed a geometric mean vanadium content of 12 ppm in 29 Western U.S. coals.

\section{Alaska Coals}

There exists an abundant amount of geochemical data relating to vanadium concentrations in Alaska coals and coal ashes. Compared to other U.S. coals, the content of vanadium is generally higher in Alaskan coals.

Northern Alaska province. Rao (1968) reported an average vanadium content of $9.1 \mathrm{ppm}$ in 12 Northern Alaska raw-coal samples; ash samples of the same coals contalned an average 66 ppm vanadium. Conwell and Triplehorn (1976) reported anomalously high values of vanadium (1,500 ppm) in a Kukpuk River, Northern Alaska coal-ash sample. A similar coal-ash sample from Cape Thompson, Northern Alaska contained 1,000 ppm vanadlum. Rao (1980) Eound a range in vanadium content of 7 to $133 \mathrm{ppm}$ and a mean of $31 \mathrm{ppm}$ vanadium in 38 Cape Beaufort region raw-coal samples. In addition, he reported vanadium contents in ash samples of the same coals; the range cited was 51 to 257 ppm and the mean was 132 ppm. Rao and Wolff (198I) reported vanadium contents For two Northern Alaska coals, a subbituminous B seam from Meade River and a high-volatile bituminous seam from Sagwon Bluffs. The former registered $12 \mathrm{ppm}$ vanadium on a raw-coal basis and $270 \mathrm{ppm}$ vanadium on a coal-ash basis; the latter contained 200 ppm vanadium on a raw-coal basis and 310 ppm vanadium on a coal-ash basis. Affolter and others (1981) llsted a range in vanadium content of 2 to $200 \mathrm{ppm}$ and a geometric mean of $15 \mathrm{ppm}$ in 54 Utukok River Quadrangle whole-coal samples.

Cook Inlet-Susitna province. Rao (1968) reported an average vanadium concentration of 31.1 ppm in 22 Matanuska Valley raw-coal samples; ash samples of the same coals contained an average content of 189 ppm vanadium. Rao and Wolff (1981) analyzed and reported on vanadium concentracions in seams from the Castle Mountaln and Premler mines of the Matanuska Valley. The lower seam from the Castle Mountain mine, a high-volatile bituminous coal contalned 58 ppm vanadium on a raw-coal basis and 320 ppm vanadium on a coal-ash basis. A high-volatile bituminous coal from the Premier mine contalned 58 ppm vanadium on a raw-coal basls and 380 ppom vanadium on a coal-ash basis. Merritt ( 1985 b) listed a mean content of 80 ppm vanadium in 31 Matanuska Valley coal-ash samples. 
Rao (1968) reported an average vanadium concentration of 6.7 ppm in eight Kenal fleld raw-coal samples; ash samples of the same coals contained an average content of 65 ppm vanadium. Rao and Wolff (1981) cited a vanadium concentration of $45 \mathrm{ppm}$ in a raw-coal sample of the subbituminous C-ranked Cabin bed of the Kenal field; a coal-ash sample of this seam contalned $400 \mathrm{ppm}$ vanadium. Affolter and others (1981) found a range of 15 to $100 \mathrm{ppm}$ vanadium and a geometric mean of 50 ppm vanadium in 10 Kenai quadrangle whole-coal samples. In addicion, they reported a range of 10 to $200 \mathrm{ppm}$ vanadium and a geometric mean of $50 \mathrm{ppm}$ vanadium in 34 Seldovia Quadrangle whole-coal samples. Merritt and others (1987) cited an average vanadium content of 385 ppm in 31 Kenai fleld coal-ash samples.

Conwell (1977) found a range of 300 to 700 ppm vanadium and a mean content of 500 pprin vanadium in seven Beluga fleld coal-ash samples. Rao and Wolff (1981) reported vanadium contents of two coals from the Susitna lowland of southcentral Alaska. The subbituminous $C$ Waterfall seam of the Beluga fleld contalned 37 ppm vanadium on a raw-coal basis and $360 \mathrm{ppm}$ on a coal-ash basis. Lower and upper benches of a sunflower Creek ligntte of the Yentna field contained an average of 9.2 ppm vanadium on a raw-coal basis and $230 \mathrm{ppm}$ vanadium on a coal-ash basis. Based on samples of $\mathrm{s} 1 \mathrm{x}$ coal beds from the Tyonek Formation, Beluga fleld, Affolter and Stricker (1984) found that the concentration of vanadium varied directly with the ash content of the coals. Rao and Smlth (1987) reported vanadium concentrations in coal-ash samples of five seams from the Chuitna district, Beluga fleld. The average vanadium contents of the seams going downsection are as follows: Blue Seam (15 samples), 236 ppm; Red 3 Seam (13 samples), 308 ppm; Red 2 Seam (26 samples), $206 \mathrm{ppm}$; Red I Seam (16 samples), $343 \mathrm{ppm}$; and the Purple Seam (5 samples), $420 \mathrm{ppm}$.

Rao and Wolff (1981) also analyzed and reported on vanadium content in a Ifgnite seam from CoaI Creek, Broad Pass fleld. A raw-coal sample contained 69 ppm vanadium and a coal-ash sample contained 350 ppm vanadium.

Nenana province. Rao (1968) listed an average vanadium content of 9.1 ppm in 25 Nenana basin whole-coal samples; ash samples of the same coals contained an average 69 ppm vanadium. Rao and Wolff (1981) reported average vanadium concentrations in seven samples of five seams from the Nenana basin. including the No. 2, No. 4, No. 6 (three splits--top, niddle, and lower), Moose, and Caribou seams, all of subbltuminous $C$ rank. Raw coal samples contalned an average 39 ppm vanadium and coal-agh samples contalned an average $300 \mathrm{ppm}$ vanadium. Affoltex and others (1984) found a range of 15 to 100 ppra vanadium and a geometrlc mean of 20 ppm vanadium in 20 Healy Quadrangle whole-coal samples. Affolter and Strlcker (1987) 11sted an average vanadium concentration of $16 \mathrm{ppm}$ tn two whole-coal samples of Seam No. 3, Ustbell1 Mine.

Rao (1968) reported an average vanadium content of 4.8 ppm in three raw-coal samples of the Jarvis Creek fleld; ash samples of the same coals contained an average 47 ppw vanadium. Rao and Wolff (1981) found a vanadium content of $32 \mathrm{ppm} 1 \mathrm{n}$ a raw-coal sample of a subbituminous C-ranked seam from Ober Creek, Jarvis Creek fleld; an ash sample of this coal contained 280 ppm vanadium. Belowich (1987) listed an average vanadium content of 30 ppm in 27 Jarvis Creek field whole-coal samples. 
Rao and Wolff (1981) analyzed the subbltuminous C-ranked main searo from the Litcle Tonzona River field, western Nenana province. A raw-coal sample contained 77 ppm vanadium and a coal-ash sample contalned 560 ppm vanadium.

Alaska Peninsula province. Conwell and Triplehorn (1978) found an average vanadium concentracion of 161 ppm in elght Alaska Peninsula coal-ash samples.

Gulf of Alaska province. Rao (1968) reported an average vanadium concentration of $2.0 \mathrm{ppm}$ in five Bering River fleld raw-coal samples and an average 88 ppm vanadlum in ash samples of the same coals. Smith and Rao (1987) clted an average concencration of 198 ppm vanadium in 20 Bering River field coal-agh samples.

Yukon-Koyukuk province. Rao and Wolff (1981) analyzed and reported vanadium contents in the high-volatile bituminous main seam of the Tramway Bar field. A raw-coal sample showed $120 \mathrm{ppm}$ vanadium and a coal-ash sample showed $320 \mathrm{ppm}$ vanadium. 


\section{PROFILE 75 - YTTERBIUM}

Symbol: Yb

Atomic number: 70

Atomic weight: 173.04

\begin{tabular}{ll} 
& \multicolumn{1}{c}{$\frac{\text { Coal }}{-3 p p m}$} \\
Alaska & $0.2-3 p$ p \\
U.S. & $0.1-1.5$ ppm \\
World & N.E.
\end{tabular}

$$
\begin{aligned}
& 0-\frac{\text { Ash }}{30} \mathrm{PPm} \\
& <2-25 \text { Ppm } \\
& \text { N. E. }
\end{aligned}
$$

Ytcerbium is a rare-earth element assoclated with silicate minerals. Turekian and Wedepoh1 (1961) reported the following average ytterbium concentrations in common sedimentary rocks: shales, $2.6 \mathrm{ppmi}$ sandstones, $4.0 \mathrm{ppm}$; and carbonates, $0.5 \mathrm{ppm}$. The U.S. National Committee for Geochemistry (1980) cited an average worldwide ytterbium concentration in coal of $0.5 \mathrm{ppm}$.

\section{United States Coals}

Sharkey and others (1975) found that ytterbium occurred in 62 percent of 13 U.S. raw coals analyzed and that it ranged in concentration from $<0.1$ to $0.5 \mathrm{ppm}$. Swanson and others (1976) found an average ytterbium concentration of 0.8 ppm in 601 U.S. whole-coal samples. The U.S. National Committee for Geochemlstry (1980) reported an average overall ytterblum concentration in U.S. coals of $1.0 \mathrm{ppm}$. In addition, they clted an average ytterblum content of $0.5 \mathrm{ppm}$ for U.S. subbituminous coals and 1.5 ppm for U.S. Iignites. Ytterblum ranges from <0.2 to 23 ppm in the ashes of U.S. coals and exhibits the following average concentrations in coals of varlous rank: anthracites, 8 ppm; low-volatile bituminous coals, $10 \mathrm{ppm}$; medium-volatile bituminous coals, 9 ppm; high-volatile bituminous coals, 10 ppm; and subbituminous coels and 11gnites, 4 ppm (Los Alamos Scientiflc Laboratory, 1976).

Appalachian region. Swanson and others (1976) reported a geometric mean of $0.7 \mathrm{ppm}$ ytterbium in 331 Eascern U.S. whole-coal samples. Gluskoter and others (1977) listed a geomerric mean of 0.73 ppm ytterbium in 14 Appalachian region coals.

Interior region. Swanson and others (1976) reported a geometric mean ytterbium content of $0.7 \mathrm{ppm}$ in 194 Interior regton whole-coal samples. Gluskoter and others (1977) listed a geometr1c mean of 0.53 ppm ytterbium in 56 Illinols basin coals.

Western region. Swanson and others (1976) reported a geometric mean ytterblum content of $0.3 \mathrm{ppm}$ in 93 Western region whole-cosl samples and $1.5 \mathrm{ppm}$ In 34 Texas whole-coal sampies. Gluskoter and othera (1977) listed a geometric mean of 0.34 ppm ytterblum in 22 Western U.S. coals.

\section{Alaska Cools}

Compared to other U.S. coals, the content of ytterbium is higher in Alaska coals. 
Northern Alaska province. Conwell and Triplehorn (1976) reported a ytterbium content of $30 \mathrm{ppm}$ in a Kukpuk River coal-ash sample and $7 \mathrm{ppm}$ in a Cape Thompson coal-ash sample. Affolter and others (1981) found a range in $y$ terbium concentration of $<i$ to $3 \mathrm{ppm}$ and a geometric mean of $0.5 \mathrm{ppm}$ in 54 Utukok Rlver Quadrangle whole-coal samples.

Cook Inlet-Susitna province. Affolter and others (1981) reported a range in ytterbium content of 0.5 to $2 \mathrm{ppm}$ and a geometric mean of $1 \mathrm{ppm}$ in 10 Kenai Quadrangle whole-coal samples. In addition, they listed a range of 0.2 to $2 \mathrm{ppm}$ ytterbium and a geometric mean of 0.5 ppm ytterbium in 34 Seldovia Quadrangle wholemcoal samples.

Conwell (1977) clted a range of 7 to 15 ppm ytterblum and a mean of 12 ppm ytterblum in seven Beluga field coal-ash samples. Based on samples of slx coal beds from the Tyonek Formation, Beluga field, Affolter and Stricker (1984) found that the concentration of ytterblum varled directly with the ash content of the coals.

Nenana province. Affolter and others (1981) reported a range of 0.3 to 3 ppm ytterbium and a geometric mean of 0.7 ppm ytterblum in 20 healy Quadrangle whole-cosl samples. Affolter and Sericker (1987) listed an average ytterbium content of $0.4 \mathrm{ppm}$ in two whole-coal samples of Seam No. 3 , Ustbelit Mine.

Alaska Peninsula province. Conwe1l and Triplehorn (1978) clted an average ytcerblum content of $5 \mathrm{ppm}$ in elght Alaska Peninsula coal-ash samples. 


\section{PROFILE 76 - YTTRIUM}

Symbol: Y

Atomic number: 39

$$
\begin{aligned}
& 0 . \frac{\text { Coa } 1}{0.3 .0} \mathrm{ppm} \\
& <0.1-60 \mathrm{ppm} \\
& 0-100 \mathrm{ppm}
\end{aligned}
$$

Atowic welght: 88.905

$$
\begin{aligned}
& 0-3 \overline{00} \text { ppm } \\
& 0-700 \text { p pm } \\
& 0-800 \text { ppm }
\end{aligned}
$$

Yttrlum is a metallic element that has many metallurgical applications. It is not a rare-earth element, but it occurs in many rare-earth minerals. It is found in association with varlous silicate minerals. Turekian and Wedepoh1 (1961) reported the following average yttrium concentrationg in common sedimentary rocks: shales, $26 \mathrm{ppm}$; sandstones, $40 \mathrm{ppm}$; and carbonates, $30 \mathrm{pPm}$.

Yetrlum is one of the elements of environmental concern in coal. It generally occurs in coal in appreclably greater concentration than its estimated average concentration in the earth's crust (Aver1tt, 1975).

\section{World Coals}

Berkow1tz (1979) reported a maximum ytertum concentration in coal ash of $800 \mathrm{gm} / \mathrm{ton}$ and an average yttrium concentration of $100 \mathrm{gm} / \mathrm{ton}$. The U.S. National Comlttee for Geochemistry (1981) cited a worldwide average yttrium content in coal of $10 \mathrm{ppm}$.

\section{Onfted States Coals}

Sharkey and others (1975) found that yttrium occurred in 100 percent of 13 U.S. raw coals analyzed, and that it ranged in concentration from 3 to $25 \mathrm{ppm}$. Others have reported a range in yttrium content in coal of <0.1 to 59 ppm (Los Alamos Sclentific Laboratory, 1976; Wewerka and others, 1976). Swanson and others (1976) c1ted an average yttrium content of 8 ppm 1n 601 U.S. whole-coal samples. The U.S. National Comittee for Geochemistry (1980) I1sted a U.S. average concentration in coal of $10 \mathrm{ppm}$. Yttrium ranges from 0 to $620 \mathrm{ppm}$ in ashes of U.S. coals, and exhibits the following average concentrations by rank: anthracites, 106 ppm; low-volatile bltuminous coals, $152 \mathrm{ppm}$; medium-volatile bituminous coals, $151 \mathrm{ppm}$; high-volatile bituminous coals, $102 \mathrm{ppm}$; and subbltuminous coals and lignites, 51 ppm (Los Alamos Sclentific Laboratory, 1976).

Appalachian region. Los Alamos Sctentiflc Laboratory (1976) listed an average yttrium concentration of $14 \mathrm{ppm}$ in 73 Appalachian region whole-coal samples. Swanson and others (1976) cited a geometric mean yttrium content of 7 ppm In 331 Eastern U.S. coals.

Interior reglon. Los Alamos Sclentific Laboratory (1976) listed an average yttrium concentration of 7.7 ppm in 53 Eastern Interior region wholecoal samples. Swanson and others (1976) cited a geometric mean yttrium content of $7 \mathrm{ppm}$ in 194 Interior region coals. 
Western reglon. Los Alamos Sclentiflc Laboratory (1976) listed an average yttrium concentration of $7.4 \mathrm{Ppm}$ in 48 Western and Southwestern Interior region whole-coal samples and 13 ppo in 51 Northern Great Plains region whole-coal samples. Swanson and others (1976) cited a geometric mean yterium content of 3 ppm in 93 western U.S. coals and 15 ppm yterium in 34 Texas coals.

\section{Alaska Coals}

Compared to other U.S. coals, the content of yttrium is higher in Alaskan coals.

Northern Alaska province. Conwell and Triplehorn (1976) reported a yttrium content of 300 ppm in a Kukpuk River coal-ash sample and 50 ppm in a Cape Thompson coal-ash sample. Affolter and others (1981) liated a range in yttrium content of 0.5 to $30 \mathrm{ppm}$ and a geometric mean of 5 ppm yttrium in 54 Utukok Rlver Quadrangle whole-coal samples.

Cook Inlet-Susitna province. Merritt (1985b) cleed a mean yttrium content of $18 \mathrm{ppm}$ in 31 Matanuska Valley coal-ash samples. Affolter and others (1981) found a range of 5 to 20 ppm yttrium and a geometric mean of $10 \mathrm{ppm}$ yterium 1n $10 \mathrm{Kenai}$ Quadrangle whole-coal samples. In addition, they found a range of 2 to 20 ppm yttrium and a geometric mean of 5 ppm yterium in 34 Seldovia Quadrangle whole-coal samples.

Conwell (1977) found a range of 70 to 150 ppm yttrium and a mean of $94 \mathrm{ppm}$ yttrium in seven Beluga fleld coal-ash samples. Based on samples of six coal beds from the Tyonek Formation, Beluga fleld, Affolter and Stricker (1984) found that the concentration of yttrlum varled directly with the ash content of the coals.

Nenana province. Affolter and others (1981) reported a range of 3 to 20 ppm yttrium and a geometric mean of 7 ppm yttrium in 20 Healy Quadrangle whole-coal samples. Affolter and Stricker (1987) cited an average yttrium content of $3.2 \mathrm{ppm}$ in two whole-coal samples of Seam No. 3, Ustbelli Mine.

Alaska Peninsula province. Conwell and Triplehorn (1978) found an average yttrlum content of 53 ppm In elght Alaska Peninsula coal-ash samples. 


$\begin{array}{ll}\text { Alaska } & 2-1 \frac{\text { Coal }}{10 \mathrm{Ppm}} \\ \text { U.S. } & 0-6,000 \mathrm{ppm} \\ \text { World } & \text { N.E. }\end{array}$

$$
\begin{aligned}
& 50-\frac{A s h}{500} \mathrm{ppm} \\
& 0-20,000 \mathrm{ppm} \\
& 0-10,000 \mathrm{ppm}
\end{aligned}
$$

Zinc is a metalifc element that is found in the mineral sphalerite (ZnS) or zinc blende. Tureklan and Wedepohl (1961) reported the following average zinc concentrattons $1 n$ common sedimentary rocks: shales, $95 \mathrm{ppm}$; sandstones, $16 \mathrm{ppm}$; and carbonates, $20 \mathrm{ppm}$. Orhe1m (1979) c1ted these clarke values for zinc: earth's crust, $70 \mathrm{ppm;}$ so1l, $50 \mathrm{ppm}$; plant ash, 1,400 ppm; and water, $0.01 \mathrm{ppm}$. 2inc occurs in coal in appreciably greater concentration than its estimated average concentration in the earth's crust (Averttt, 1975). Unusual concentrations of 21 nc are found in some coals and IIgnites of Texas and North Dakota and may be recovered in commercial quantities (Altschuler and Johnston, 1976).

Zinc is one of the elements of environmental concern in $\cos 1$, and one of the elemeats generaliy inorganically combined in coal and showing least organic affinity (Ruch and others, 1974). It 1s typlcally concentrated in the mineral matter of coal, being retalned in high-temperature ash and over 95 percent retained in low-temperature ash. Even a few ppm of zinc in carbon electrodes is harmful to the production of aluminum by the electrolytic process since it causes brittleness of the finlshed metal (Stach and others, 1982). Anomalously high zinc may result from core-hole samples contaminated by driling fluids and drill pipe.

\section{World Coals}

Abernethy and Gibson (1963) cited an average zinc concentration in coal of $46 \mathrm{ppm}$. The U.S. National Compttee for Geochemistry (1980) 11sted an average zinc content of $50 \mathrm{ppm}$ in U.S. coals. Berkowitz (1979) found a maximum zinc concentration in coal ash of $10,000 \mathrm{gm} / \mathrm{ton}$ and an average zinc concentration of $200 \mathrm{gm} / \mathrm{ton}$.

\section{United States Coals}

Sharkey and others (1975) Eound that zinc occurred in 100 percent of 13 U.S. raw cosis analyzed and that it ranged in concentration from 3 to $80 \mathrm{ppm}$. Others have cited a range of 0 to $51 \mathrm{ppm} z 1 \mathrm{nc}$ 1n U.S. coals (Los Alamos Sclentific Laboratory, 1976). Swanson and others (1976) listed an average zinc content in 601 U.S. coals of $27.9 \mathrm{ppw}$. The U.S. National Committee For Geochemistry (1980) reported an average zinc content of 39 ppio in U.S. coala.

Zinc has been found to range from 0 to 1.6 percent in ashes of U.S. coals and exhibits the following. average concentrations by rank: low-volatile bituminous coals, 231 ppm; medium-volatile bituminous coals, 195 ppm; and high-volatile bituminous coals, 310 ppm (Los Alamos Sclentific Laboratory, 1976). 
Appalachian region. Los Alamas Scientiflc Laboratory (1976) reported an average zlac content of 7.6 ppm in 73 Appalachlan whole-coal samples. Swauson and others (1976) cited a geometric mean zinc content of $12.8 \mathrm{ppm}$ in 33 Lastern U.S. coals. Gluskoter and others (1977) listed a geometric mean zinc content of 19 ppm in 23 Appalachian coals.

Interior region. Los Alamos Sclentific Laboratory (1976) reported an average zinc content of $44 \mathrm{ppm}$ in 53 Eastern Interlor region whole-coal samples. Swanson and others (1976) cited a geometric mean zinc content of $58 \mathrm{ppm}$ in 194 Interfor region coals. Gluskoter and others (1977) listed a geometric mean zinc content of 87 ppr in 113 Illinols basin coals.

Western region. Los Alamos Scientific Laboratory (1976) reported an average zinc content of $108 \mathrm{ppm}$ in 48 Western and Southwestern Interior region whole-coal samples and $59 \mathrm{ppm}$ in 51 Northern Great Plains region whole-coal samples. Swanson and others (1976) clted a geometr1c mean zinc content of 12.8 ppm in 93 Western region coals and 28 ppm in 34 Texas coals. Gluskoter and others (1977) 11sted a geometrlc mean zinc content of 5.0 ppw In 29 Western U.S. coals.

\section{Alaska Coals}

There exists an abundant amount of geochemical data relating to $z$ inc concentrations in Alaska coals and coal ashes. Compared to other U.S. coals, the content of zinc in Alaskan coals is similar.

Northern Alaska province. Conwell and Triplehorn (1976) reported anomalously high values of zinc $(2,650 \mathrm{ppm})$ in a Kukpuk River, Northern Alaska coal-ash sample. In addition, they reported a zinc content of 177 ppm In a Cape Thompson coalmash sample. Rao (1980) found the concentration of zinc in 38 Cape Beaufort region samples to be within the range of other U.S. coals. He quoted a range of 5.8 to $107 \mathrm{ppm}$ and a mean of $26 \mathrm{ppm} z$ inc in raw-coal samples; coal ashes of the samples showed a range of 47 to 290 ppm zinc and a mean of 110 pom zinc. Rao and Wolfe (1981) reported zinc contents In raw-coal and coal-ash samples of three Northern Alaska coals: a subbituminous B-ranked seam frow Walnwright contained 14 ppm zinc in a raw-coal sample and $237 \mathrm{ppm} z i \mathrm{nc}$ in a coal-ash sample; a subbltuminous B-ranked seam Erom Meade River contalned $16 \mathrm{ppm}$ zinc in a raw-coal sample and $366 \mathrm{ppm}$ zinc in a coal-ash sample; and a high-volatile bltuminous coal from Sagwon Bluffa contained $64 \mathrm{ppm} z$ inc in a raw-coal sample and $101 \mathrm{ppm}$ zinc in a coal ash sample. Affolter and others (1981) listed a range of 2 to $67 \mathrm{ppm} z i n c$ and a geometric mean of 7.7 ppm zinc in 54 Utukok Rlver Quadrangle whole-coal samples.

Cook Inlet-Susitna province, Rao and Wolff (1981) cited a zinc content of $18 \mathrm{ppm}$ in a raw coal sample of the high-volatfle bituminous lower seam of the Castle Mountaln mine, Matanuska Valley; a coal-ash sample of the same coal contained 99 ppm zinc. Rao and Wolff (1981) also analyzed a highvolatile bituminous seam from the Premler Mine, Matanuska Valley; a raw-coal sample contained 57 ppm zinc, and a coal-ash sample contained 370 ppr zinc. Merritt ( $1985 \mathrm{~b}$ ) cited a mean zinc concentration of 22 ppm in 31 Matanuska valley coal-ash samples. 
Rao and Wolff (1981) found a zinc content of 11 ppm tn a raw-coal sample of the subbituminous $C$ Cabin bed from the Kenal field; a coal-ash sample of the same coal contalned $95 \mathrm{ppm}$ zinc. Affolter and others (1981) reported a range of 2.6 to $24 \mathrm{pptr} z$ inc and a geometrlc mean of $7.1 \mathrm{ppm}$ zinc in 10 Kenai Quadrangle whole-coal samples. In addftion, they listed a range of 2.1 to $110 \mathrm{ppm}$ zinc and a geometric mean of $7 \mathrm{ppm}$ zinc in 34 Seldovia Quadrangle whole-coal samples. Merritt and others (1987) cited an average zinc content of $58 \mathrm{ppm}$ In 31 Kenai fleld coal-ash samples.

Conwell (1977) found a range of 70 to $163 \mathrm{ppm}$ zinc and a mean of $118 \mathrm{ppm}$ zinc in seven Beluga fleld coal-ash samples. Rao and Wolff (1981) reported a raw-coal zinc concentration of 19 ppm and a coal-ash zinc concentration of $182 \mathrm{ppm}$ in the subbltuminous C-ranked Waterfall seam of the Beluga fleld. They also analyzed upper and lower benches of a Sunflower Creek lignite seam from the Yentna fleld; a raw-coal sample showed 4.4 ppm 21 inc and a coal-ash sample showed 110 ppm zinc. Merritt (1987a) listed a range of 20 to 563 ppu zinc and an average content of $122 \mathrm{ppm}$ zinc in 45 susitna lowland coal-ash samples. Rao and Smith (1987) presented data for zinc contents in coal-ash samples of flve seams from the Chulcna district, Beluga coal field. Average zinc concentrations by seam going downsection are ss follows: Blue Seam ( 15 samples), 285 ppm; Red Seam ( 13 samples), 197 ppm; Red 2 Seam (26 samples), 206 pp⿴; Red 1 Seam (16 samples), 126 Pp⿴; and Purple Serm (5 samples), $104 \mathrm{ppm}$.

Rao and wolff (1981) cited a raw-coal zinc content of 22 ppm and a coal-ash zinc content of 110 ppm in a 11 gnite seam from Coal Creek, Broad Pass Field.

Nenana province. Rao and Wolff (1981) reported average zinc contents in seven samples of flve different seams from the Nenana basin. The subbituminous $C$ seams include the No. 2, No. 4, No, 6 (top, middle, and lower benches), Moose, and Caribou seams. Raw-cosl samples contained an average $19 \mathrm{ppm} z i n c$, and coal-ash samples contalned an average $86 \mathrm{ppm} z$ inc. Affolter and others (1981) reported a range of 2.3 to $46 \mathrm{ppm} z 1$ inc and a geometric mean of $8.8 \mathrm{ppm}$ zinc in 20 tealy Quadrangle whole-coal samples. Affolter and Strlcker (1987) found an average zinc concentratton of 2.2 ppm in two wholecoal samples of Seam No. 3, Usibelli Mine.

Rao and Wolff (1981) clted a raw-coal zinc content of 18 ppm in a subbituminous C seam from Ober Creek, Jarvis Creek fleld; an ash sample of the same coal contalned $160 \mathrm{ppm}$ zinc. Belowich (1987) 1isted an average zinc content of $614 \mathrm{ppm}$ In $27 \mathrm{Jarvls}$ Creek fleld whole-coal samples.

Rao and Wolff ( 1981 ) also analyzed the subbituminous $C$ main seam from the Little Tonzona River fleld. A raw coal sample contalned 55 ppm zinc and a coal-ash sample cantalned 403 ppm zinc.

Alaska Penlngula province. Conwell and Triplehora (1978) reported an average zinc concentration of 117 ppm 1n elght Alaska Peninsula coal-ash samples.

Gulf of Alaska province. Smith and Rao (1987) c1ted an average zinc concentration of 677 ppm in 20 Bering River Eleld coal-ash samples. 


\section{PROFILE 78 - ZIRCONIUM}

Symbol: 2 r

Atomic number: 40

Atomic welght: 91.22

$$
\begin{aligned}
& \text { Alaska } \\
& \text { L.S. } \\
& \text { World }
\end{aligned}
$$

$$
\begin{aligned}
& \text { 2-1 Coa } 1 \\
& 50 \mathrm{Ppm} \\
& 5-300 \mathrm{ppm} \\
& \text { N. E. }
\end{aligned}
$$

$$
\begin{aligned}
& 100-\frac{\text { Ash }}{800} \mathrm{ppm} \\
& 100-1,500 \mathrm{ppm} \\
& 0-5,000 \mathrm{ppm}
\end{aligned}
$$

Z1rconfum is a metallic element that is found predominantly in the mineral zircon $\left(2 \mathrm{ZS1O}{ }_{4}\right)$ but also commonly associated with other stlicate minerals. Tureklan and Wedepoh1 (1961) reported the following average zircondum concentrations in common sedimentary rocks: shales, 160 ppm; sandstones, $220 \mathrm{ppm}$; and carbonates, $19 \mathrm{ppm}$.

21rconium generally occurs in coal in appreciably greater concentration than 1ts estlmated average concentration in the earth's crust (Averitt, 1975). It is one of the elements showing least organic affinity, and is generally concentrated in the mineral matter of coal (Ruch and others, 1974). Berkowitz (1979) clted a maximum zirconium concentration in coal of $5,000 \mathrm{gm} /$ ton.

\section{United States Coals}

Sharkey and others (1975) found that zirconium occurred in 100 percent of 13 U.S. raw coals analyzed, and that it ranged in concentration from 28 to $300 \mathrm{ppm}$. Others have reported a range of zircontum content in U.S. coals of 8 to 133 ppm (Los Alanos Sclentiflc Laboratory, 1976). Swanson and others (1976) cited an average zirconfum concentration of 26.2 ppm in 601 U.S. coa1s. The U.S. National Committee for Geochemistry (1980) reported an average zirconlum content of $30 \mathrm{ppm}$ in U.S. coals.

21rconium has been found to range in content in ashes of U.S. coals from 100 to $1,450 \mathrm{pPm}$, and shows the following average concentrations by rank: anthracites, 688 ppm; low-volat1le bicuminous coals, 458 ppw; medium-volat1le bituminous coals, 326 ppr; high-volatile bituminous coals, $41 \mathrm{l}$ ppm; and subbltuminous coals and lignites, $245 \mathrm{ppm}$ (Los Alamos Scientific Laboratory, 1976).

Appalachlan region. Swanson and others (1976) clted a geometric mean zirconfum concentration of $30 \mathrm{ppm}$ in 331 Eastern U.S. whole-coal samples. Gluskoter and others (1977) listed a geometric mean zircontum concentration of 41 ppw in 19 Appalachian coals.

Intertor region. Swenson and others (1976) c1ted a geometric mean 21 conlum concentration of $10 \mathrm{ppm}$ in 194 Interlor region whole-coal samples. Gluskoter and others (1977) listed a geometric mean zirconium concentration of 41 ppm in 88 Illinols basin coals.

Western region. Swanson and others (1976) cited a geometric mean zirconium concentration of $15 \mathrm{ppm}$ in 93 Western region whole-coal samples and 50 ppm in 34 Texas whole-coal samples. Gluskoter and others (197i) l1sted a geometric mean zirconium concentration of $26 \mathrm{ppm}$ in 26 Western U.S. coals. 


\section{Alaska Coals}

There exists abundant data on zirconium concentrations in Alaska coals and coal ashes. Compared to other U.S. coals, the content of zirconium in Alaskan coals is stantlar.

Northern Alaska province. Rao (1968) reported an average zirconium content of 24.4 ppm in 12 Northern Alaska raw-coal samples; ash samples of the same coals contained an average $192 \mathrm{ppm}$ zircontum. Conwell and Triplehorn (1976) found a zirconium content of $300 \mathrm{ppm}$ in a Kukpuk River, Northern Alaska coal-ash sample and 200 ppu in a Cape Thompson coal-8sh sample. Rao (1980) found the concentration of zircontum in 38 Cape Beaufort region coals to be within the range of other U.S. coals. Zirconium ranged from 21 to $253 \mathrm{ppw}$ in raw-coal samples and had a mean content of $103 \mathrm{ppm}$. It ranged from 47 to $1,170 \mathrm{ppm}$ in coal-ash samples and had a mean content of 508 ppm. Rao and Wolff (1981) analyzed three Northern Alaska coals: a subbituminous B seam from Walnwright contalned 28 ppm zircondum on a raw-coal basis and $470 \mathrm{ppm}$ zirconium on a coal-ash basis; a subbituminous B seam from Meade River contalned 25 ppm zirconium on a raw-coal basis and 580 ppm zircontum on a coal-ash basis; and a high-volatile bituminous coal from Sagwon Bluffs contalned 110 ppm zircontum on a raw-coal basls and $170 \mathrm{ppm}$ zirconium on a coal-ash basis. Affolter and others (1981) found a range of 2 to $100 \mathrm{ppm}$ and a geometric mean of 20 ppm in 54 Utukok River Quadrangle whole-coal samplea.

Cook Inlet-Sustena province. Rao (1968) cited an average zirconium content of $41.0 \mathrm{ppm}$ in 22 Matanuska Valley raw-coal samples and $348 \mathrm{ppm}$ zircontum in ash samples of the same coals. Rao and Wolff (1981) found a raw-coal zirconium content of 67 ppw and a coal-ash zircontum content of $370 \mathrm{ppm}$ in the high-volatile bytuminous lower seam of the Castle Mountain mine, Matanuska Valley. A high-volatile bituminous coal from the Premier mine, Matanuska Valley contalned 40 ppm zircontum on a raw-coal basis and $260 \mathrm{ppm}$ on a coal-ash basis. Merritt (1985b) listed a mean zirconium content of 71 ppm in 31 Matanuska Valley coal-ash samples.

Rao (1968) cited an average z1rconium content of 6.2 ppm in eight Kenai field raw-coal samples and $63 \mathrm{ppm}$ zircontum in ash samples of the same coals. Rao and Wolff (1981) reported a zirconfum content of 46 ppm in a raw-coal sample of the subbituminous C Cabin bed of the Kenai field; an ash sample of the same coal contained 410 ppm zirconium. Affolter and others (1981) 11sted a range in zircontum content of 7 to $50 \mathrm{ppm}$ and a geometric mean zirconium content of 20 ppm in 10 Kenai quadrangle whole-coal samples. In addition, they 11sted a range of 7 to $70 \mathrm{ppm} z$ zrcontum and a geometric mean of $15 \mathrm{ppm}$ zirconium in 34 Seldovia Quadrangle whole-coal samples. Merritt and others (1987) found an average zircontum content of 216 ppm in 31 Kenal fleld coal-ash samples.

Conwell (1977) reported a range in zircontum content of 150 to $300 \mathrm{ppm}$ and a mean content of $178 \mathrm{ppm} z 1 \mathrm{rconium}$ in seven Beluga field coal-ash samples. Rao and wolff (1981) reported zirconium contents of 43 ppm and $420 \mathrm{ppm}$ for raw-coal and coal-ash samples of the subbituminous C-ranked Waterfall seam, Beluga field. In addition, they reported average zirconium 
contents of 24 ppm and 615 ppm for raw-coal and coal-ash samples of the lower and upper benches of a Sunflower Creek lignite from the Yentna fleld. Based on samples of six coal beds from the Tyonek Formation, Beluga field, Affolter and Stricker (1984) found that the concentration of zircontum varied directly with the ash content of the coals. Rao and Sulth (1987) analyzed and reported on zirconlum concentrations in five seams frow the Chultna district, Beluga field. Average zirconlum contents by sear golng downsection are as follows: Blue Seam (15 samples), 171 ppm; Red 3 Seam (13 samples), 153 ppm; Red 2 Sean (26 samples), 195 ppm; Red l Seam (16 samples), 152 ppm; and Purple Seam (5 samples), 244 ppm.

Rao and Wolff (1981) reported a raw-coal z1rconium content of 79 ppm and a coal-ash zircontum content of $400 \mathrm{ppm}$ in a Coal Creek 1ignite seam from the Broad Pass fleld.

Nenana province. Rao (1968) clted an average zircontum concentration of 7.2 ppm in 25 Nenana basin whole-coal samples and $60 \mathrm{ppm}$ zirconium in ash samples of the same coals. Rao and Wolff (1981) analyzed seven samples of Elve subbituminous $C$ seams from the Nenana basin tncluding the No. 2, No. 4 , No. 6 (top, middle, and lower benches), Moose, and Carlbou seams; they found an average raw-coal zirconlum content of $38 \mathrm{ppm}$ and a coal-ash zirconfum content of $293 \mathrm{ppm}$. Affolter and others (1981) reported a range in zirconium content of 7 to 70 ppm and a geometric mean of 15 ppm in 20 healy Quadrangle whole-coal samples. Affolter and Stricker (1987) Eound an average zirconfum content of 16 ppm in two whole-coal samples of Seam No. 3, Usibeli1 Mine.

Rao (1968) listed an average zirconfum content of 5.7 ppm in three Jarvis Creek fleld raw-coal samples and an average 61 ppm zirconium in ash samples. Rao and Wolff (1981) found $57 \mathrm{ppm}$ zirconlum in a raw-coal sample of a subbltuminous C seam from Ober Creek, Jarvis Creek fleld; an ash sample of the same coal contalned $500 \mathrm{ppm}$ zirconium. Belowich (1987) found an average zirconium concentration of $16 \mathrm{ppm}$ in 27 Jarvis Creek field whole-coal sampies.

Rao and holff (1981) also analyzed and reported zircontum contents in the subbltuminous $C$ main seam from the Little Tonzona River fleld; a raw cosl contained 44 ppm zirconium and a coal-ash sample contained 320 ppr zirconium.

Alaska Peninsula province. Conwe11 and Triplehorn (1978) ciced an average zircontum concentration of $238 \mathrm{ppm}$ in eight Alaska Pentnsula coal-ash samples.

Gulf of Alaska province. Rao (1968) found an average ztrcontum content of $10.7 \mathrm{ppm}$ in flve Bering River field raw-coal samples; ash samples of the same coals contalned an average zirconlum content of $341 \mathrm{ppm}$. Smith and Rao (1987) reported an average zircontum content of 232 ppm in 20 Bering River fleld coal-ash samples.

Yukon-Koyukuk province. Rao and Wolff (1981) analyzed the high-volat1le bltuminous maln seam from the Tramway Bar fleld. They reported a raw-coal zirconium content of $130 \mathrm{ppm}$ and a coal-ash zirconfum content oi $3 j 0 \mathrm{ppm}$. 
Accessory elements --- trace elements.

Baseline concentrations -- the existent abundances of certaln minor or trace elements in coals or associated rocks.

Chemlcal constitution of coal --- the elements or component parts of coal.

Clarke -- the average concentration of an element in the earth's crust.

Coal analysis --- the determination of the various constituents of coal by chemical methods.

Concentration - accumulation of elements or compounds in a coal that add or detract from its value.

Contaminant -- undesirable elements or compounds within or intimately associated with a coal.

Contamination --- Infiltration of trace elements or other harmful agents into surface or groundwater resources.

Content --- amount of a given element in a unft amount of coal, usually in weight-percent or PPE basis.

Control technology -- system for the prevention of toxic trace element emission or infiltration.

Fly ash -- particulate matter in stack gases on whlch way be entrained certain toxic trace elements.

Heavy metals --- metallic elements with an atomic number over 21 and generally found in trace amounts in coal.

Impurity -- contaminants of coal, Including various trace elements, that detract from 1 ts value.

Minor elements -- trace or accessory elements.

Nontoxic -- without harmful concentrations of trace elements or other substances.

Parts pex million (ppm) - a method of stating the content of an element in cosl or other substance.

Toxic -- harmful or polsonous concentrations of trace elements or other substances.

Trace element --- an element present in very small concentrations in coal or other subscances; minor or accessory elements.

Washability curve -- a curve or graph showing the results of a series of floac-and-sink tests. 


\section{REFERENCES}

Abernethy, R.F., and Glbson, F.H., 1963, Rare elements in coal: U.S. Bureau of Mines Information Circular $8163,69 \mathrm{p}$.

Affolter, R.H., and Stricker, G.D., 1984, Geochemistry of selected coal beds from the Beluga coal field, Cook Inlet region, Alaska: Geological Society of America Abstracts with Programs 1984, 80th annual meeting, Cordilleran section, Anchorage, Alaska, v. 16, no. S, P. 265. 1987, Variations in element distribution of coal from the Usibell1 Mine, Healy, Alaska, in Rao, P.D., ed., Focus on Alaska's coal '86: University of Alaska MLneral Industry Research Laboratory Report 72 , p. $91-99$.

Affolter, R.H., Simon, F.O., and Stricker, G.D., 1981, Analysis of coal samples from the Healy, Kena1, Seldovia, and Utukok River Quadrangles, Alaska, in Rao, P.D., and Wolff, E.N., eds., Focus on Alaska's coal ' 80 : Universtey of Alaska Mineral Industry Research Laboratory Report No. 50, P. $236-266$.

Altschuler, 2.S., and Johnston, J.E., 1976, Coal resources, a continuing assessment, in EPA prograw conference report--fuel cleaning program; coal: U.S. Environmental Protection Agency Report 600/7-76-024, P. $11-15$.

Averitt, Paul, 1961, Coal reserves of the United States-A progress report, January 1, 1960: U.S. Geological Survey Bulletin 1136, P. 40-42.

1975, Coal resources of the United States, January I, 1974: U.S. Geological Survey Bulletin 1412, p. 79-86.

Averitt, Paul, Breger, I.A., Swanson, V.E., Zubovic, Peter, and Gluskoter, H.J., 1972, Minor elements in coal---a selected bibliography, July 1972, In Geological Survey Research 1972: U.S. Geological Survey Professional Paper 800-D, p. 169-171.

Belowich, M.A., 1987, Bastual trends in coal petrographtc and elemental composition with applicacions toward seam correlation, Jarvis Creek coal field, Alaska, in Rao, P.D., ed., Focus on Alaska's coal '86: University of Alaska Mineral Industry Research Laboratory Report 72, p. 300-335.

Berkow1tz, N., 1979, An introduction to coal cechnology: Academic Press, New York, $345 \mathrm{p}$.

Cavallaro, J.A., Deurbrouck, A.W., Gibbon, G.A., Hattman, E.A., and Schulcz, H., 1978, A washability and analytical evaluation of potential pollution from trace elements in coal, In Karr, Clarence, Jr., ed., Analytical methods for coal and coal products, v. I: Academic Press, New York, P. 435-464.

Conwell, C.N., 1976, Samples from Healy coal fleld analyzed: Alaska Division of Geological and Geophysical Surveys Alaska Mines and Geology Bulletin, v. 25, no. 1, p. $1-4$.

1977. Cook Inlet-Susitna corl flelds: Alaska Division of Geological and Geophysical Surveys unpublished report, $32 \mathrm{p}$.

Conwe1I, C.N., and Triplehorn, D.M., 1976, High-qualicy coal near Point Hope, northwestern Alaska, In Short notes on Alaskan geology-1976: Alaska Division of GeologicaI and Geophysical Surveys Geologic Report S1, P. $31-35$.

Gluskoter, H.J., 1975, Mineral matter and trace elements in coal: American Chemical Soclety, Advances in Chemistry Series, no. 141, ch. 1, p, 1-21. 
Gluskoter, H.J., Ruch, R.R., Miller, W.G., Cahili, R.A., Dreher, G.8., and Kuhn, J.K., 1977, Trace elements in coal; occurtence and distribution: IIlinois State Geological Survey Circular 499, $154 \mathrm{p}$.

Hamrin, C.E., 1977, Cacalyc1c accivity of coal mineral matter: Springfield, Virginla, National Technical Information Service Annual Report FE-2233-3.

Hatch, J.R., and Swanson, V.E., 1977, Trace elements in Rocky Mountain coals, in Murry, D.K., ed., Geology of Rocky Mountaln coal--a symposium:

Colorado Geologlcal Survey Resources Serles I, p. 143-165.

Hessley, R.R., Reasoner, J.W., and Riley, J.T., 1986, Coal sclence: New York, Wiley-Interscience, $269 \mathrm{p}$.

Horne, J.C., Ferm, J.C. Carucclo, F.T., and Baganz, B.P., 1978, Depos1t1onal models in coal exploration and mine planning in Appalachian region: American Association of Petroleum Geologists Bulletin, v. 62, no. 12, p. $2379-2411$.

Los Alamos Sclentific Laboratory, 1976, Environmental contamination from trace elements in coal preparation wastes.

McClung, J.D., and Geer, M.R., 1979, Properties of coal and coal impurities, In Leonard, J.W., ed., Coal preparation: American Institute of Mining, Metallurglcal, and Petroleum Engineers, Inc., New York, p. 1.1-1.79.

Merritt, R.D., 1985a, Coal atlas of the Nenana basin, Alaska: Alaska Division of Geological and Geophysical Surveys Public-data File 85-41, 197 p., scale $1: 250,000,5$ sheets.

$1985 \mathrm{~b}$, Coal atlas of the Matanuska Valley, Alaska: Alaska Division of Geological and Geophysical Surveys Public-data File 85-45, 270 P.. scale $1: 100,000,3$ sheets.

1987a, Coa1 atlas of the Sustena lowland, Alaska: Alaska Dfvision of Geological and Geophysical Surveys Report of Investigations (In press).

$198 \pi$, Alaska's low-sulfur coal resources may be world's largest: Journal of Coal Quality, v. 6, no. 3, p. 104-108.

Merrltt, R.D., Lueck, L.L., Rawlinson, S.E., Belowich, M.A., Goff, K.M., Clough, J.G., and Reinink-Smith, Linda, 1987, Southern Kenai Peninsula (Homer district) coal-resource assessment and mapping project final report: Alaska Division of Geological and Geophysical Surveys Public-data File 87-15, $125 \mathrm{p} .$, scales $1: 250,000$ and $1: 63,360$, 14 sheets.

Mraw, S.C., DeNeufv1lle, J.P., Freund, Howard, Baset, Zeinab, Gorbaty, M.L., and Wright, F.J., 1983, The science of mineral mater 1n coal, in Gorbaty, M.L., Larsen, J.W., and Wender, Irving, eds., Coal science, v. 2: Academic Press, New York, p. 1-63.

O'Gorman, J.V., and Walker, P.L., Jr., 1972, Mineral matter and trace elements in U.S. coals: The Pennsylvania State Untversity College of Earth and Mineral Sciences, Research and Development Report No. 61, Interim Report No. 2, 183 p.

O'Ne1l, R.L., and Suhr, N.H., 1960, Determination of trace elements in lignite ashes: Applied Spectroscopy, v. 14, no. 2, p. 45-50.

Orhelm, Alv, 1979, Geochemlcal affinlties as exploration and classification tools, in Argall, G.O., Jr., ed., Coal exploration, v. 2: Miller Freeman Publications, Inc., San Francisco, p. 328-346.

Rao, C.P., and Gluskoter, H.J., 1973, Occurrence and distribution of minerals in Illinois coals: Illinois Geological Survey Circular 476, 56 p. 
Rao, P.D., 1968, Distribution of certain winor elements in Alaskan coals: Fałrbanks, Universicy of Alaska Mineral Industry Research Laboratory Report 15, 47 \%.

1974, Distribution and significance of major, minor, and trace elements in Arctic Alaskan coals, final report submitted to U.S. Bureau of Mines: U.S. Department of the Interior Contract No. GO $133125,38 \mathrm{p}$. 1976. Characterization of Alaska's coals, in Rao, P.D., and Wolff, E.N., eds., Focus on Alaska's coal '75: University of Alaska Mineral Industry Research Laboratory Report 37, p. 150-157.

1980, Petrographic, mineralogical and chemical characterization of certaln Arctic Alaskan coals from the Cape Beaufort reglon: University of Alaska Mineral Industry Research Laboratory Report 44, $66 \mathrm{p}$.

Rao, P.D., and Smith, Jane, 1987, Characterization of Chultna coal from deep drill core with possible applications to seam correlation, In Rao, R.D., ed., Focus on Alaska's coal 186: Undversity of Alaska Mineral Industry Research Laboratory Report 72, p. 157-182.

Rao, P.D., and Wolff, E.N., 1979, Characterization and evaluation of washability of Alaskan coals, final technical report for phase I, selected seams from Nenana, Jarvis Creek, and Matanuska coal fields: U.S. Department of Energy/ET/13350-T1, Contract No. DOE ET78-G-01-8969, $31 \mathrm{p}$.

1980, Characterization and evaluation of washabllity of Alaskan coals, final technical report for phase II, selected seams from northern Alaska, Broad Pass, Tramway Bar, Beluga, Yentna, Kenal, and Nenana cos1 flelds: U.S. Department of Energy/ET/13350-T2, Contract No. DOE ET-78-G-018969, 47 p.

1981, Petrographic, mineralogical, and chemical characterization of certain Alaskan coals and washability products, in Rao; P.D., and Wolff, E.N., eds., Focus on Alaska's coal '80: Universicy of Alaska Mineral Industry Research Laboratory Report 50, P. 194-235.

Renton, J.J., 1982, M1neral matter in coal, ln Meyers, R.A., ed., Coal structure: Academic Press, New York, p. 307-308.

Ruch, R.R., Gluskoter, H.J., and Shimp, N.F., 1974, Occurrence and distribution of potentially volatile trace elements in coal: L11inois State Geological Survey Environmental Geology Notes 72, 96 p.

Selvig. W.A., and Gibson, F.H., 1956, Analyses of ash from United States coals: U.S. Bureau of Mines Bulletin 567, $33 \mathrm{p}$.

Sharkey, A.G., Jr., Kessler, T., and Frlede1, R.A., 1975, Trace elements in coal dust by spark-source mass spectrometry, In Babu, S.P., ed., Trace elements in fuel: American Chemical Soclety Advances in Chemistry Series No. 141, Washington, D.C., p. 48-56.

Simon, J.A., and Hopkins, M.E., 1973, Geology of coal, In Cassidy, S.M., ed., Elements of practical coal mining: Soclety of Mining Engineers of the American Institute of Mining, Metallurgical, and Petroleum Engineers, Inc., New York, p. 11-39.

Smlth, Jane, and Rao, P.D., 1987, Geology and coal resources of the Bering River fleld, in Rao, P.D., ed., Focus on Alaska's coal '86: Universicy of Alaska Mineral Industry Research Laboratory Report 72, p. 266-299.

Somerville, M.H., and Elder, J.L., 1977, Compartson on trace element analysis of Norch Dakota ifgnite laboratory ash with Lurgt gasifier ash and their use in environmental analysis, in Ayer, G.A., and Massoglia, M.F., eds.. Environmental aspects of fuel conversion technology III, Proceedings of Symposium of Environmental Aspects of Fuel Conversion Technology: U.S. Environmental Protection Agency Report EPA-600/7-78-063. 
Stach, E., Mackowsky, M.-Th., Telchmuller, M., Taylor, G.B., Chandra, D., and Teichmiller, R., 1982, Stach's textbook of coal petrology, 3rd edition: Gebruder Borntraeger, Berlin, p. 162-164, 170-171.

Swanson, V.E., MedIIn, J.H., Hatch, J.R., Coleman, S.L., Wood, G.H., Jr., Woodruff, S.D., and Hildebrand, R.T., 1976, Collection, chemical analysis and evaluations of coal samples in 1975: U.S. Geological Survey Open-file Report 76-468, 503 p.

Tldball, R.R., and Ebens, R.J., 1976, Regional geochemical baselines in solls of the Powder Rlver basin, Montana-Wyoming: Wyoming Geological

Assoclation Guldebook, Twenty-eighth Annual Field Conference, p. 299-310.

Torrey, S., ed., 1978, Trace contamlnants Erom coal: Noyes Data Corporation Pollution Technology Revlew No. 50, Park Ridge, N.J., 294 p.

Turek1an, K.K., and Wedepoh1, K.H., 1961, Distribution of the elements in some major units of the earth's crust: Geologlcal Soclety of America Bulletin, v. 72, no. 2, p. 175-192.

U.S. Department of Energy, 1978, Coal loan guarantee program (P.L. 94-163); Elnal environmental impact statement: U.S. Deparcment of Energy DOE/EIS $0004, p$. III $-9, v-36$.

U.S. National Committee for Geochemistry, 1980, Trace element geochemistry of coal resource development related to environmental quality and health: National Acadeny Press, Washington, D.C.

Valkovid, Vlado, 1983, Trace elements In coal: CRC Press, Inc., Boca Raton, Florida, v. I, 210 p., v. II, 281 P.

Wewerka, E.M., W1lliams, J.M., and Vanderborgh, N.E., 1976, Contaminants in coals and coal resldues, in EPA program conference report fuel cleaning program; coal: U.S. Environmental Protection Agency EPA-600/7-76-024, p. 17-31.

Wewerka, E.M., W1lllams, J.M., Vanderborgh, N.E., Waguer, P., Wanek, P.L., 01sen, J.D., 1978, Trace element characterization and removal/recovery from coal and coal wastes: Natianal Technical Information Services, Springfield, Virginia.

Wewerka, E.M., Williams, J.M., Wangen, L.E., Bertlno, J.P., Wanek, P.L., Olsen, J.D., Thode, E.F., and Wagner, P., 1979, Trace element characterization of coal wastes: U.S. Environmental Protection Agency Report EPA-600/7-79, 144 p.

Zubovic, Peter, Stadnichenko, Ta1sia, and Sheffey, N.B., 196la, Geochemistry of minor elements in coals of the Northern Great Plains coal province: U.S. Geological Survey Bulletin 1117-A, 58 p. $196 \mathrm{lb}$, Chemical basis of minor element associations in coal and other carbonaceous sediments, in Short papers in the geologic and hydrologic sciences: U.S. Geological Survey Professional Paper 424-D, p. 345-348. 1964, Distribution of minor elements in coal bedg of the Eastern Intertor region: U.S. Geological Survey Bullet1a 1117-B, 41 p. 1966a, Distribution of minor elements in coals of the Appalachian region: U.S. Geological Survey Bulletio $1117-\mathrm{C}, 37 \mathrm{p}$. 1966b, Minor element distribution in coal samples of the Intertor coal province, in Coal sclence: Amertcan Chemical Soclety's Advances in Chemistry Series 55, P. 232-247. 
Zubov1c, Peter, Sheffey, N.B., and Stadnichenko, Ta1s1a, 1967, D1stribution of minor elements in some coals in the western and southwestern regions of the Interlor coal province: U.S. Geological Survey Bulletin 1117-D, $33 \mathrm{p}$.

Zubovic, Peter, Stadnichenko, T., and Sheffey, N.B., 1960, Comparative abundance of the minor elements in coals from different parts of the United States, in Short papers in the geological scleaces: U.S. Geological Survey Professlonal Paper 400-B, p. 87-88. 1960, The association of minor elements with organic and inorganic phases of cosl: U.S. Geological Survey Professional Paper 400-B, P. 84-87.

Zubovic, Peter, Hatch, J.R., and Medl1a, J.H., 1979, Assessment of the chemical composition of coal resources, 1n Proceedings of U.N. Symposium on World Coal Prospects, Katowice, p. 15-23. 